\title{
The Impact of Terrorism on Social Capital: Evidence from the 2015 Charlie Hebdo Paris Shooting
}

\author{
Shawn J. McCoy* \\ University of Nevada, Las Vegas \\ Ian K. McDonough ${ }^{\dagger}$ \\ University of Nevada, Las Vegas \\ Punarjit Roychowdhury \\ Indian Institute of Management Indore
}

August 19, 2019

\begin{abstract}
We examine the impact of terrorism on social capital by exploiting variation in the 2014 European Social Survey administration dates coupled with the 2015 Charlie Hebdo attack in Paris, France. Using the difference-in-differences estimator, we find that the attack had a positive, causal impact on the overall level of social capital among French respondents. Further, the effect seems to be driven by an increase in institutional and interpersonal trust, as well as by engagement in social networks. This rise in social capital peaks in the immediate aftermath of the terrorist attack but subsequently decays to pre-attack levels within approximately one month.
\end{abstract}

Keywords: Charlie Hebdo, Difference-in-Differences, Social Capital, Terrorism JEL Classification: D74, F51, F52, Z13

\footnotetext{
*Department of Economics, University of Nevada, Las Vegas. e-mail: shawn.mccoy@unlv.edu. 4505 S Maryland Pkwy, Box 6005, Las Vegas, NV 89154, USA.

${ }^{\dagger}$ Corresponding Author. Department of Economics, University of Nevada, Las Vegas. e-mail: ian.mcdonough@unlv.edu. 4505 S Maryland Pkwy, Box 6005, Las Vegas, NV 89154, USA.

${ }^{\ddagger}$ Department of Economics, Indian Institute of Management Indore. email: punarjitr@iimidr.ac.in. RauPithampur Road, Indore, Madhya Pradesh 453556, India.
} 


\title{
The Impact of Terrorism on Social Capital: Evidence from the 2015 Charlie Hebdo Paris Shooting
}

August 19, 2019

\begin{abstract}
We examine the impact of terrorism on social capital by exploiting variation in the 2014 European Social Survey administration dates coupled with the 2015 Charlie Hebdo attack in Paris, France. Using the difference-in-differences estimator, we find that the attack had a positive, causal impact on the overall level of social capital among French respondents. Further, the effect seems to be driven by an increase in institutional and interpersonal trust, as well as by engagement in social networks. This rise in social capital peaks in the immediate aftermath of the terrorist attack but subsequently decays to pre-attack levels within approximately one month.
\end{abstract}

Keywords: Charlie Hebdo, Difference-in-Differences, Social Capital, Terrorism JEL Classification: D74, F51, F52, Z13 


\section{Introduction}

Social scientists frequently demonstrate the importance of social capital - or the "features of social organizations, such as trust, norms, and [social] networks" - in promoting efficient political institutions as well as a country's overall level of economic success (Putnam et al. 1993 p. 167). ${ }^{1}$ Of late, and motivated by a sharp, ninefold increase in the number of terrorist-related events over the last two decades, new attempts have been made to quantify the role of terrorism in explaining a country's level of social capital (Chanley 2002; Putnam 2002; Collins 2004; Gross et al. 2004; Paxton 2005; Huddy and Feldman 2006; Bali 2007; Gassebner et al. 2008; Sander and Putnam 2010; Sinclair and LoCiero 2010; Blomberg et al. 2011; Arvanitidis et al. 2016).

Despite attracting the attention of social scientists at large, two notable limitations in the literature persist. First, existing studies tend to focus on narrowly construed definitions of social capital, namely trust in institutions and interpersonal trust. Second, the extant analyses utilize empirical methods that are insufficient for quantifying the causal effect of terrorism on a nation's level of social capital. Motivated by these shortcomings, we utilize the 2015 Charlie Hebdo shooting in France, coupled with the random and staggered nature that respondents were interviewed in the 2014 wave of the European Social Survey (ESS), to estimate the causal effect of terrorism on multiple dimensions of social capital using the difference-in-differences (DID) estimator.

As noted above, the number of terrorist attacks has increased dramatically over the last two decades. According to the Heritage Foundation (2016), there were 141,966 terrorist incidents between 1970 and 2014 worldwide resulting in 32,685 deaths in 2014 alone. ${ }^{2}$ The

\footnotetext{
${ }^{1}$ Some of the more notable works on social capital and the link between social capital and economic success include, but are not limited to: Arrow 1972; Coleman 1988, 1990; Putnam et al. 1993; Putnam 1995; Fukuyama 1995; Helliwell and Putnam 1995; Knack and Keefer 1997; La Porta et al. 1997; Glaeser et al. 2000; Durlauf 2002; Glaeser et al. 2002; Forte et al. 2015; Helliwell et al. 2017.

${ }^{2}$ This figure is without a doubt alarming. But to provide some perspective, according to the WHO, 1.25 million individuals were killed in traffic-related incidents in 2013 alone (see http://www.who.int/gho/road_safety/mortality/number_text/en/; last accessed on November 25, 2018). Nonetheless, the upward trend in terror-related casualties is of obvious concern, especially related to the impact on social capital.
} 
geographic distribution of terrorist activity has also evolved. Before 2014, the vast majority of attacks were concentrated in developing countries. However, in recent years terrorism has become more prevalent in developed countries (Kim and Kim, 2017). This trend is especially true in Europe. According to a report by the Institute for Economics and Peace (2016), deaths from terrorism increased in OECD member countries to 577 in 2015 from 77 in 2014, with the majority of this increase occurring in European countries. Underscoring this finding, a recent article published in the New York Post (August 18, 2017) on the state of terrorism in Europe notes that, although terrorism is inherently abnormal, unfortunately "it is the new norm [for Europe]," and that "the situation is worsening, not improving." ${ }^{3}$ As well, The Heritage Foundation's Robin Simcox states that, "Islamist terrorism poses a grave danger to Europe. Its face and its methods are always evolving, but it is not going anywhere" (Heritage Expert: Terror in Europe is Growing, Spreading, Changing, June 23, 2017).

Evidence to Simcox's claims are a series of major terrorist attacks in the West by Islamic extremist groups. One noteworthy attack, which is the focal point of this paper, was the Charlie Hebdo shooting in Paris, France. On January 7, 2015, two armed individuals shot and killed 11 people and injured 11 others at the office of the French weekly news magazine Charlie Hebdo. It was later found that the religious extremist group Al-Qaeda helped prepare the attack because the newspaper had published cartoons offensive to the central figure of Islam, the Prophet Muhammad. The attack was followed by intense global media coverage, social media exposure epitomized by YouTube footage of the Charlie Hebdo attackers shooting a French police officer in the streets of Paris, and massive public rallies following the attack. The incident appeared twice and seven times as the cover story of Le Monde and L'Humanité in January 2015, respectively, both of which are leading daily French newspapers. Shortly following the Charlie Hebdo shooting, Europe experienced the November 2015 Paris attacks, the 2016 Nice attack, the 2016 Munich shopping center shooting, the 2016 Berlin attack, the

\footnotetext{
${ }^{3}$ http://nypost.com/2017/08/18/why-terrorists-are-so-focused-on-attacking-europe/; last accessed on November 25, 2018.
} 
2016 Brussels bombings, the 2017 Manchester Bombing, the 2017 Westminster Bridge attack in London, the 2017 London Bridge attack, the 2017 Barcelona attack, and most recently the September 2017 London subway attack.

It is widely known that terrorist attacks have substantial economic costs. These costs include damages to physical and human capital, attenuated foreign direct investment (FDI) and tourism, misallocation of resources due to increased uncertainty, increased transaction costs due to heightened security measures, and increased adverse health effects among individuals who have directly or indirectly witnessed the terror attacks (Frey et al. 2007; Smith et al. 2009; Metcalfe et al. 2011; Kim and Kim 2017). Studies that investigate the macroeconomic impacts of terrorism find that the costs in terms of GDP, consumption, and economic growth are considerable, especially in countries with repeated and chronic exposure to terrorism (Abadie and Gardeazabal 2003; Blomberg et al. 2004; Eckstein and Tsiddon 2004).

In addition to these macroeconomic and health implications, it has been argued that terrorist attacks may have profound impacts on a country's level of social capital. Theoretically, however, the impact of terrorism on social capital is ambiguous. On the one hand, some have argued that terrorist incidents may strengthen bonds between citizens, increasing both trust among individuals and confidence in institutions (Chanley 2002; Putnam 2002; Collins 2004). This response can be interpreted as a "rally effect" according to which a large-scale terrorist attack leads to a collective loss of sense of security and, in the face of a national public threat, results in citizens placing more trust in political institutions and displaying a more unified sense of identity (Perrin and Smolek 2009; Woods 2011). On the other hand, others have argued that terrorism may foster feelings of insecurity, raising distrust in people of different ethnicities, cultures or religions, and/or in people and the government in general (Blomberg et al. 2011; Brehm and Rahn 1997; Huddy et al. 2002; Uslaner et al. 2004; Gould and Klor 2016). According to Tallman (2007), this potential negative effect of terrorism on social capital can be viewed as an "anti-rally effect" or a "jading effect." This ambiguity 
with respect to social capital stands in contrast to the impact of terrorism on physical and human capital, which is necessarily negative.

To the best of our knowledge, we provide the first quasi-experimental evidence indicating a causal impact of a terrorist attack on a nation's level of social capital. Specifically, we find that the 2015 Charlie Hebdo terrorist attack led to a significant increase in social capital immediately following the incident thus inducing a "rally effect" amongst the im-

pacted populace. However, this rise in social capital peaks in the immediate aftermath of the terrorist attack and subsequently decays to pre-attack levels within approximately one month. Further, we show that this effect is driven primarily by increases in institutional and interpersonal trust, as well as an increase in engagement in social networks. Additionally, we explore various dimensions of heterogeneity with respect to the impact of the attack on social capital and further show that our results are robust to various falsification tests, alternative control groups, the inclusion of additional controls, and an alternative identification strategy. Finally, we provide suggestive evidence that our results for the Charlie Hebdo attack are externally valid relative to the overall pattern between terrorism and social capital when using the broader population of terrorist attacks in Europe.

\section{Literature Review}

Over the last decade, numerous works have explored the influence of terrorism on social capital. Drawing mainly on the experience of the United States, many of these studies find that terrorism is associated with an increase in the level of social capital. With respect to institutional trust, Chanley (2002), Collins (2004), Putnam (2002), and Sinclair and LoCicero (2010) conclude that terrorist attacks, or even fear of a terrorist attack, is associated with greater trust in government and other institutions. This boost in political trust can be interpreted as a rally effect; however, researchers note that this consensus starts to dissipate as people revert to prior political positions. Collins (2004), drawing on the $9 / 11$ experience, 
reports that intense solidarity builds momentum 1-2 weeks after the event, remains at peak levels for roughly two months, and then gradually returns to prior levels.

With respect to interpersonal trust, Gross et al. (2004), Paxton (2005), and Putnam (2002) further find a positive association with terrorism. These studies assert that terrorismrelated events strengthen the bond between citizens and heighten social trust. For example, Putnam (2002) argues that the 9/11 terrorist attack led to Americans putting aside their differences and bonding across ethnic, racial, class, and partisan lines. As noted by Paxton (2005), the enhanced solidarity following 9/11 appeared to be at the group level, which generated its own process of conflict between groups (Collins 2004; Sander and Putnam 2010). However, these group-specific conflicts declined towards normalcy within 6-9 months following the attack (Paxton 2005; Sander and Putnam 2010).

In contrast to these studies, other work exploring the impact of terrorism in European countries finds that terrorist attacks are associated with a neutral, or even a negative effect, on social capital. For example, Bali (2007), Gassebner et al. (2008), and Montalvo (2011) find a negative or zero effect of terrorism on the electoral support of the incumbent government. Likewise, Huddy and Feldman (2006) show that fear of terrorist attacks in the aftermath of 9/11 made people less likely to trust others. Blomberg et al. (2011) also report a negative influence of terrorism on trust, but acknowledge that the effects could, in principle, go in any direction, depending on the composition and characteristics of the affected population.

Among existing papers looking at the impact of terrorism on social capital, the study by Arvanitidis et al. (2016) is perhaps the closest to our work. Using data drawn from the European Social Survey (ESS) for the years 2004, 2012, and 2014, the authors find that terrorist incidents can trigger social dynamics that affect trust attitudes; however, the authors conclude that these effects are short-lived and dissipate rapidly. Specifically, the authors use four major terrorist events as case studies in their empirical examination: the 2004 Madrid train bombings, the 2011 Oslo and Utoya attacks, the 2014 Jewish Museum shooting in Belgium, and the 2015 Charlie Hebdo shooting in France. The outcome variables, in their study, 
include composite indices of institutional and interpersonal trust. The independent variable of interest is 'Terrorism elapsed days,' which counts the number of days elapsed between the time of the terrorist event and the interview date for each ESS participant in the corresponding country. Using an OLS framework, for the 2004 Madrid train bombings, they find evidence of an inverted U-shaped relationship between the terrorist incident and public trust in government and institutions; institutional trust increases in the first few days following the attack, but as time elapses, this initial strengthening of institutional trust levels off and subsequently exhibits signs of reverting towards pre-terrorist attack levels. However, for the 2015 Charlie Hebdo attack, they find evidence of a linear and negative effect of terrorism on trust attitudes. Although the authors argue that the timing of survey administration may be responsible for the contradictory results, one cannot rule out the possibility that unobserved country specific factors might be driving their results.

Like Arvanitidis et al. (2016), we also use the Charlie Hebdo attack to examine the impact of terrorism on social capital. However, our study differs in three main respects. First, Arvanitidis et al. (2016) only explore how post-terror trust attitudes change over time, and therefore only use observations from the period after the Charlie Hebdo attack. Our focus, instead, is on estimating the causal effect of a large scale terror attack on social capital, as well as understanding the temporal dynamics following the attack. As such, we use observations prior to and after the terrorist attack and implement a carefully designed empirical strategy comparing the difference in social capital between a country that is subject to the attack and countries that are not, both before and after the terrorist incident. Second, the set of elements of social capital that we examine is much broader compared to Arvanitidis et al. (2016). Specifically, while Arvanitidis et al. (2016) focus primarily on institutional and interpersonal trust, the set of outcomes we consider include these two elements of social capital as well as indices capturing engagement in social networks, norms of reciprocity, ethnic tolerance, and an overall index of social capital. As noted by the OECD (2001) and the Australian Bureau of Statistics (2002), a statistical framework for social capital 
should ideally contain multiple elements relevant to networks, social norms, and values that facilitate cooperation within and among groups. Lastly, we explore the impacts across various dimensions of heterogeneity including one's religiosity, political orientation, and exposure to television.

\section{Data}

\subsection{Data Description}

The data for this study comes from the 2014 wave (round 7) of the European Social Survey (ESS) that was administered between April 2014 and September 2015. The 2014 ESS is a representative survey used to gather information on behaviors, beliefs, attitudes, and demographics of individuals across 22 European countries. Although the seventh round of the data is cross-sectional in nature, we exploit the fact that individual survey start times and survey end times were recorded, thus implicitly providing and additional dimension of time. Further, the scheduled interview times were randomly set by ESS survey administrators. This feature of the data, coupled with knowing the country of residence when the survey was taken, allows us to place the Charlie Hebdo shooting in a meaningful way with respect to individuals exposed to the attack (treatment vs. control) and individuals that completed the survey before or after the incident. As such, we are able to exploit the arguably random nature of the attack to estimate the causal effect of terrorism on social capital using a DID framework.

Motivated by the existing literature on social capital, our outcome of interest is a composite index of social capital comprised of measures on institutional trust, interpersonal trust, engagement in social networks, norms of reciprocity, and ethnic tolerance (Putnam et al. 1993; Fukuyama 1997; Durlauf and Fafchamps 2005). Each of these elements of social capital are constructed by standardizing, within each country, underlying survey responses to be 
mean zero with a standard deviation equal to one. ${ }^{4}$ Once these measures are standardized, and similar to Kling et al. (2007), an equal weighted average of $z$-scores is taken to form component-level indices, and subsequently a broader index of social capital. Missing data related to a particular component of social capital is replaced using country specific means calculated over the non-missing data. Furthermore, the indices are constructed in such a way that for each element of social capital, higher (lower) values in the indices correspond to higher (lower) levels of social capital. For example, individuals with higher index values of institutional (interpersonal) trust, have greater trust in institutions (in other individuals) compared to individuals with lower values of the index. Similarly, higher values in the indices capturing engagement in social networks, reciprocity norms, and ethnic tolerance correspond to greater participation in social networks, more positive attitudes towards norms of reciprocity among individuals, and higher levels of tolerance with respect to other ethnic groups, respectively. It should be noted that while there is no universal definition of social capital, there is general consensus that key features of social capital include the components we use in constructing our aggregate measure of social capital (Putnam et al. 1993; Australian Bureau of Labor Statistics 2002; Halman and Luijikx 2006).

Covariates used in our most robust model specifications include measures for age and age squared, years of education and years of education squared, an indicator for gender, and a full set of indicators classifying households within the distribution of income. Conditioning on these covariates, and using the broadest window of time possible, results in a sample size of 12,466 observations with 1,765 respondents residing in France (the treatment group) and 10,701 individuals residing in one of the control countries. ${ }^{5}$

The 2014 wave of the ESS includes individuals sampled in: Austria, Belgium, Switzerland, Czech Republic, Germany, Denmark, Spain, Finland, United Kingdom, Republic of Ireland, Netherlands, Norway, Portugal, Sweden, and Slovenia. Among these countries, Belgium,

\footnotetext{
${ }^{4}$ See Table A1 in the supplemental appendix for the list of survey questions that we have used to construct the different elements of social capital.

${ }^{5}$ The sampling window of 68 days before the attack and 47 days after the attack is the maximum window of time we could use given the countries in our sample.
} 
Switzerland, Germany, Spain, and Netherlands share a common border with France while Austria, Czech Republic, Denmark, Finland, United Kingdom, Republic of Ireland, Norway, Portugal, Sweden, and Slovenia do not. Henceforth, in our empirical work we consider three distinct set of control countries: all countries other than France; all countries other than France that share a border with France (we refer to this subset of controls as bordering countries); and all countries other than France that do not share a border with France (we refer to this subset of controls as non-bordering countries). To deal with the complex nature of how the data was collected across countries, sampling design weights were used throughout the analysis. Descriptive statistics broken down by treatment status and time can be found in supplemental appendix Tables A2 to A4.

\subsection{Data Visualization and Pre-Trends}

The difference-in-differences estimation strategy will identify the causal effect of the terror attack on social capital if the average change in social capital among individuals in France would have been proportional to the average change in social capital among individuals in the set of controls in the absence of the attack. However, this assumption cannot be explicitly tested since we do not observe the counterfactual outcome in France. Instead, we provide graphical evidence that the evolution of each social capital metric in the period of time leading up to the attack in France parallels the evolution of each outcome in the set of control countries.

Figure 1 plots kernel-weighted local polynomials for each social capital metric of interest expressed as a function of time since the attack and fit separately for each group (treatment vs. control) and each time period (pre vs. post). Visual inspection of each figure indicates that in the period of time leading up to the attack, the trend in each social capital met-

ric of interest in France resembles that of the control group. This qualitative conclusion is strengthened in a statistical sense by the observation that in each trend plot, the 95 percent confidence interval on the trend in France generally contains the 95 percent confidence 
interval on the trend in the control.

\section{Empirical Strategy}

\subsection{Baseline Econometric Model}

Given the ability to exploit the plausibly exogenous nature of the Charlie Hebdo terrorist attack combined with knowing the day, month, and year that individual surveys were started and completed, we are able to employ the DID estimator according to (1) as a means of examining the impact of terrorism on social capital. ${ }^{6}$ Specifically, letting $i$ denote an individual surveyed in country $m$ at time $t$, our baseline DID models take the form:

$$
\begin{aligned}
Z_{i m t}= & \alpha_{1}+\beta \cdot \text { Treat }_{m} \times \text { Post }_{t}+ \\
& +C_{m}^{\prime} \omega_{1}+D_{i}^{\prime} \omega_{2}+T_{t}^{\prime} \omega_{3}+\epsilon_{i m t} .
\end{aligned}
$$

Here, Treat $_{m}$ is an indicator variable set equal to one for any individual in our sample located in France, and zero otherwise. Likewise, Post $t_{t}$ is an indicator variable set equal to one for any individual in our sample that was surveyed after the Charlie Hebdo terror attack. $C_{m}^{\prime}$ is a set of country fixed effects, $T_{t}^{\prime}$ is a complete set of week fixed effects, and $D_{i}^{\prime}$ is a set of demographic controls including: second-order polynomials in age and education (in years); a binary variable indicating if the respondent is female; and a set of categorical variables indicating the decile of the respondent's household's total net income. Further, we estimate equation (1) multiple times using our broad measure of social capital, as well as

\footnotetext{
${ }^{6}$ To the best of our knowledge there were no other major, non-terror related incidents that could be confounding the events of Charlie Hebdo (see a timeline of events here: https://www.bbc.com/news/world-europe17299605; last accessed on November 25, 2018). With that said, there were multiple smaller incidents resulting in fatalities that occurred over the following two days after the attack at Charlie Hebdo. Most notably on January 8th an individual with ties to the Charlie Hebdo assailants shot and killed a police officer and injured a city employee in the Montrouge area, and on January 9th this same assailant took employees and customers hostage at a kosher supermarket in the Porte de Vincenne area. The standoff ended with elite forces storming the store and killing the assailant; four hostages were also killed with three others injured. As a quick check, we drop individuals in the post period but who were surveyed on the two days following the Charlie Hebdo shooting and get qualitatively unchanged results.
} 
the various components of social capital, as our outcome of interest, $Z_{i m t}$.

Of interest to us are the coefficient estimates of the treatment group by post Charlie Hebdo interaction term, $\beta$, which captures the impact of the Charlie Hebdo terror attack on average changes in social capital, or an individual component of social capital, in France relative to the average change over the set of controls. ${ }^{7}$ If $\beta>(<) 0$, then the Charlie Hebdo attack results in an increase (decrease) in social capital. To check the sensitivity of our baseline results to the size of the sampling window, we estimate (1) for three different sampling windows: 68 days before the attack and 47 days after the attack, 47 days both before and after the attack, and 30 days both before and after the attack.

Note, the DID estimates stemming from equation (1) will identify the causal effect of the Charlie Hebdo terror attack if the average change in social capital in France would have been proportional to the average change in social capital in the set of control countries, in the absence of a terror attack happening. Since we do not observe counterfactual outcomes, we cannot explicitly test this assumption; however, we can test if the trends in our outcomes leading up to the terror attack statistically differ between the treatment and the control groups. To implement these tests, we first restrict attention to individuals sampled before

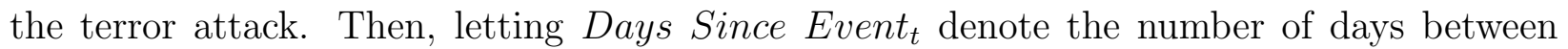
the time each respondent $i$ was surveyed and the Charlie Hebdo terror attack, we estimate variants of:

$$
\begin{aligned}
Z_{i m t}= & \alpha_{2}+\delta \cdot \text { Treat }_{m} \times \text { Days Since Event }_{t} \\
& +\rho_{1} \cdot \text { Days Since Event } t \\
& +C_{m}^{\prime} \omega_{1}+D_{i}^{\prime} \omega_{2}+T_{t}^{\prime} \omega_{3}+\epsilon_{i m t} .
\end{aligned}
$$

Of interest to us given equation (2) is the coefficient estimate of $\delta$, which captures dif-

\footnotetext{
${ }^{7}$ Note, in all specifications our index variable, $Z$, is standardized to be mean zero standard deviation equal to one. As such, the interpretation of $\beta$ can be expressed in terms of a standard deviation change in any particular outcome variable given the Charlie Hebdo terror attack.
} 
ferences in the average trend in social capital in the treatment group relative to the average trend in social capital in the control group over the period of time leading up to the terror attack. If the prior trends assumption holds, then this coefficient estimate should be statistically indistinguishable from zero.

\section{$4.2 \quad$ Temporal Dynamics}

In the preceding analysis, we utilize the DID estimator to assess the average impact of the Charlie Hebdo terror attack on various measures of social capital. Implicit in the prior specification given by equation (1) is that the estimated treatment effect of the attack is persistent, in a constant sense, through time. However, the effect of the terror attack on social capital may be increasing or decreasing with respect to the number of elapsed days since the attack.

We proceed by quantifying how the treatment effect of Charlie Hebdo varies over time. To do this, we first compute the log of the number of days that have elapsed since the beginning of the attack for each individual in our sample sampled after the attack, $\ln (\text { Days Elapsed })_{t}$, such that $\left.\ln (\text { Days Elapsed })_{t}=\ln (\text { Days Since Event })_{t}\right)$ if Days Since Event $t_{t}>0$, and is otherwise equal to zero. ${ }^{8}$ We subsequently estimate variants of an expanded DID regression model given by:

$$
\begin{aligned}
Z_{\text {imt }}= & \alpha_{3}+\pi_{1} \cdot \text { Treat }_{m} \times \text { Post }_{t} \\
& +\pi_{2} \cdot \text { Treat }_{m} \times \text { Post }_{t} \times \ln \left({\text { Days Elapsed })_{t}}\right. \\
& +\theta_{3} \cdot \ln (\text { Days Elapsed })_{t}+C_{m}^{\prime} \omega_{1}+D_{i}^{\prime} \omega_{2} \\
& +T_{t}^{\prime} \omega_{3}+\epsilon_{\text {imt }} .
\end{aligned}
$$

\footnotetext{
${ }^{8}$ Note that the logarithmic function gives more weight to the periods of time shortly after the event; however, in the appendix we present results using a wide range of functional form assumptions.
} 
Given equation (3), the parameter of interest is,

$$
\theta_{j}=\pi_{1}+\pi_{2} \cdot \ln (\text { Days Elapsed } \text { El } \text {, }
$$

evaluated over the domain of elapsed days in our sample, $j=1, \ldots, 47$ days.

\section{$5 \quad$ Results}

We begin our formal analysis in section 5.1 by estimating equation (1), which allows us to estimate the average effect of the terror attack on each measure of social capital delineated in section (3). We then turn our attention to estimating the extent to which our estimated treatment effects captured in equation (1) vary over time in section 5.2.

\subsection{Baseline Results}

Table 1 presents coefficient estimates of the treatment group by post Charlie Hebdo interaction term, $\hat{\beta}$, obtained from estimating equation (1) separately for various standardized outcomes of interest including: social capital, trust in institutions, interpersonal trust, engagement in (informal) social networks, values/norms of reciprocity, and ethnic tolerance/tolerance of diversity. In each case demographic controls, as outlined in section 4, and week fixed effects are included. Further, we obtain estimates varying the window of time around the attack. In particular, panel (A) reports results having estimated the model using our complete sample of respondents surveyed between -68 and 47 days of the attack. In panel (B), we consider a balanced sampling window of -47 to 47 days. Likewise, we utilize a slightly smaller sampling window of -30 to 30 days in panel (C). In all cases we report Hubert-White robust standard errors. ${ }^{9}$

\footnotetext{
${ }^{9} \mathrm{~A}$ limited number of clusters at the country level persuaded our choice of not clustering for the baseline results. However, in section A.2.3 of the supplemental appendix we test the sensitivity of our baseline results to clustering at the level of country, the level of country by pre/post, and the level of country by week.
} 
Focusing first on panel (A) of Table 1, we can see that the impact of the attack was highly statistically significant for social capital broadly and institutional trust and interpersonal trust specifically. In particular, the average impact of the terrorist attack was $0.271,0.311$, 0.183 standard deviation increase in social capital, institutional trust, and interpersonal trust, respectively. The estimated effects for social networks, reciprocity, and ethnic tolerance are all positive in magnitude, but cannot be ruled out as zero in a statistical sense. ${ }^{10}$

Turning attention to panels (B) and (C) in Table 1, we see that the estimated impacts on all dimensions of social capital remain qualitatively similar, both in magnitude and statistical significance, when restricting the window of time around the attack to be -47 to 47 days and -30 to 30 days. In particular, for social capital the results range from an average increase of 0.288 to 0.272 standard deviations for the windows of time -47 to 47 days and -30 to 30 days, respectively. With respect to institutional trust, the estimated effects range from and average increase of 0.338 to 0.294 standard deviations for the windows of time -47 to 47 days and -30 to 30 days, respectively. Narrowing the window of time around the attack for interpersonal trust leads to average increases of 0.222 and 0.229 standard deviations for the windows of time -47 to 47 days and -30 to 30 days, respectively. The estimated impacts on social networks, reciprocity, and ethnic tolerance remain statistically indistinguishable from zero as the window of time around the attack narrows.

Note that Table 1 presents coefficient estimates estimating equation (1) using the full suite of demographic controls and time fixed effects. For completeness, in the supplementary online appendix and for each social capital index of interest, we report in Tables A5 to A10 coefficient estimates with and without the inclusion of these controls and also show that our main results are robust to the exclusion of countries immediately bordering France ${ }^{11}$.

\footnotetext{
${ }^{10}$ To aid in interpretation of the magnitudes of the effects of Charlie Hebdo, in supplemental appendix section A.2.4 we re-scale our difference-in-differences estimates of Charlie Hebdo in terms of the estimated effects of other model covariates.

${ }^{11}$ This provides some evidence that the effects of Charlie Hebdo were confined to France. Please refer to the supplementary appendix section A.2.1 for a complete discussion of these results as well as additional tests for the presence of spillover effects which compare the evolution of social capital in bordering countries to non-bordering countries, before and after the attack.
} 
Lastly, and as noted earlier in section 4.1 and visually inspected via Figure 1, a critical assumption required to identify the causal effect of the Charlie Hebdo attack is the existence of parallel trends in the outcome of interest prior to the attack. In effect, we are assuming that individuals in the set of control countries act as a valid counterfactual for our treated individuals residing in France. Figure 1 presents graphical evidence suggesting that the key underlying identifying assumption of our empirical models holds. Inspection of the raw data is useful for this purpose, but has its limitations. In our empirical setting, we do not utilize longitudinal data on a sample of individuals. Rather, we leverage the implicit time component in the ESS survey to estimate a DID model using a repeated cross-sections of respondents. In the traditional panel data setting, all unobserved determinants of social capital in the treatment and control group would be captured by country specific effects and ultimately be reflected in Figure 1 by level shifts in the overall trends between the treatment and the control group. In the repeated cross-sectional setting, we would want to be sure that once conditioning on the covariates included in our difference-in-differences specification, France and the controls exhibit similar pre-treatment trends in each outcome.

We provide evidence this is the case by estimating equation (2) using our broad social capital index, as well as the various individual components, as our outcome variable, $Z_{i t m}$. We estimate various specifications of equation (2) with each iteration varying the set of controls and/or sample window of time prior to the event. Finding evidence supporting the validity of the common trends assumption requires the coefficient estimate, $\hat{\delta}$, to be statistically indistinguishable from zero. All results for the pre-trend analysis can be found in supplemental appendix Tables A11 through A16. In order to illustrate how estimates of $\hat{\delta}$ change with and without the inclusion of the suite of controls, we report model estimates for each social capital index of interest separately in each table varying the modeling specification across each column.

Broadly, we find that the coefficient estimates are statistically no different from zero. There are exceptions, however, related to certain specifications associated with the institu- 
tional trust index. As illustrated in columns (1) and (2) in panel (b) of Table A14, coefficient estimates of the Treat x Days Since Event are positive and statistically significant indicating that France exhibited a different trend in the trust in institutions index in the period of time leading up to the attack; however, this is true only when conditioning our pre-treatment time period to [-47 days, 0 days]. In contrast, coefficient estimates of Treat x Days Since Event are statistically insignificant in our broader sample [-68 days, 0 days] and our most narrow sample [-30 days, 0 days]. Moreover, as shown in Table A6 in the appendix, the estimated impact of the terrorist attack on institutional trust is stable across every model specification, thus alleviating some concern that the results are driven by divergent trends in the pre-attack period. This concern is further alleviated when the broad findings from pre-trend estimates are coupled with the pre-trend figures presented earlier. However, given the crucial nature of the pre-trends assumption and credible concerns regarding threats to identification, we provide a suite of robustness checks presented in the supplemental appendix. ${ }^{12}$

\subsection{Temporal Dynamics}

Figure 2 visually displays the impact of the Charlie Hebdo attack on social capital, and its various components, over time. In all panels, the vertical axis captures the magnitude of the effect as expressed by equation (4) having first estimated equation (3). The horizontal axis, then, captures time since the event starting at day 1 and extending through day 47 .

Focusing attention to panels $(\mathrm{A})$ - (C) in Figure 2, two things become immediately apparent. First, the impact of the attack on social capital, as well as on the individual measures for institutional and interpersonal trust, is greater than 0.5 standard deviations the day following the attack. Second, though this effect is seemingly large in the immediate aftermath, the impact decays quickly over the days following the event. In particular, the el-

\footnotetext{
${ }^{12}$ In particular, we provide a very comprehensive supplemental appendix exploring threats to identification and robustness of our main results (section A.2), re-estimating our main results varying the control set to be bordering and non-bordering countries and considering spillover effects (section A.2.1), questioning the external validity of the Charlie Hebdo attack (section A.3), re-scaling our main results in terms of other observables (section A.2.4), and investigating the impact of the attack on broader attitudes towards immigrants (section A.4).
} 
evated levels of social capital, institutional trust, and interpersonal trust become statistically indistinguishable from zero at 30 days, 34 days, and 16 days after the attack, respectively.

Looking at the figure for engagement in social networks (panel (D) in Figure 2, a very similar pattern emerges. Specifically, on the day following the attack there is an increase in the normalized measure capturing engagement in social networks by roughly 0.5 standard deviations. However, the rate at which engagement in social networks returns to pre-attack levels is even faster than that documented for the broad measure of social capital, institutional trust, and interpersonal trust. In fact, after day 10 the impact is not statistically different from zero.

Next, we explore the temporal dynamics associated with the measures of reciprocity and tolerance. Although we do not find an average effect given equation (1), it could be the case that there was some impact very early on but then averaged out given the nature of the dynamics following the event. With that said, and as can be seen in panels (E) and (F) of Figure 2, the impact of the Charlie Hebdo attack on these two measures is both economically and statistically meaningless over the days following the incident.

Lastly, in Figures A1 to A6 provided in the supplemental appendix, we evaluate the sensitivity of our estimates of the temporal effects to functional form. In each figure, panels (a) and (b) plot estimates of $\theta_{j}$ allowing the variable Days Elapsed to enter equation 3 linearly and quadratically, respectively. Further, in panel (c), we replace $\ln (\text { Days Elapsed })_{t}$ with $\sqrt{\text { Days Elapsed }}$. For each social capital index, estimates of the temporal effects of the Charlie Hebdo terror attack in Figures A1 to A6 are qualitatively similar to estimates reported in Figure 2

Overall we find that the estimated causal effect of the Charlie Hebdo attack on social capital, and various factors comprising this measure, is non-trivial in the immediate aftermath of the terror incident, but tends to quickly revert to pre-attack levels. In particular, the factors driving the results associated with our broad measure of social capital are trust in institutions, interpersonal trust, and engagement in social networks. We find zero impact 
with respect to outcome measures of reciprocity and tolerance, both on average and in a temporal sense. Our results are thus in line with the findings of Chanley (2002), Putnam (2002), Collins (2004), Gross et al. (2004), Paxton (2005) and Sinclair and LoCicero (2010). As discussed in Section 2, these studies, like ours, document a positive influence of terror-related attacks on social capital that attenuates within a relatively short period of time following the attack. However, the aforementioned authors find social capital returning to normalcy over a 6-9 month time frame whereas we find effects decaying much more rapidly. Further, the findings of these previous studies are only capturing associations and are limited in making causal claims. With that said, and because our findings are much more fleeting in nature, the overall impact is arguably not as economically significant relative to the existing studies. Thus, our work further contributes to the literature by tempering expectations regarding the persistent nature of the "rally effects" stemming from a terror-related attack.

\subsection{Heterogeneity Analysis}

We next evaluate how the effects on social capital stemming from the Charlie Hebdo terror attack vary across multiple dimensions of heterogeneity. Given the often political and religious nature associated with terrorist attacks, we first explore how the effect of the Charlie Hebdo shooting varies across the distribution of one's political orientation (right vs. left) and whether one identifies as being religious (religious vs. non-religious). ${ }^{13}$ As well, given the amount of media exposure that these types of events get, we then look at how the impact of the attack varies across the distribution of television hours watched (high vs. low). ${ }^{14}$ For each dimension of heterogeneity, we divide the sample into two groups, $G 1_{i}$ and $G 2_{i}$, and test how our baseline difference-in-differences estimates vary across each group. In all cases the same set of demographic controls as outlined in section 4 and week fixed effects are included.

\footnotetext{
${ }^{13}$ Hours Watched (High) is a binary variable equal to one for any respondent reporting an above median level of hours of television watched. The variable Right Wing was constructed from each respondents' response to a question in the ESS assessing their position on the left/right scale. Right Wing is set equal to one for any respondent reporting an above median level of this scale.

${ }^{14}$ Other dimensions of heterogeneity that we explore are gender, education, employment status, and income. These additional results can be found in supplemental appendix Tables A17 and A18.
} 
To operationalize these tests, we estimate: ${ }^{15}$

$$
\begin{aligned}
Z_{\text {imt }}= & \phi_{1} \cdot G 1_{i} \times \text { Post }_{t}+\beta_{1} \cdot G 1_{i} \times \text { Treat }_{m} \times \text { Post }_{t}+ \\
& \phi_{2} \cdot G 2_{i} \times \text { Post }_{t}+\beta_{2} \cdot G 2_{i} \times \text { Treat }_{m} \times \text { Post }_{t}+ \\
& \alpha_{1} \cdot G 1_{i}+\rho_{1} \cdot G 1_{i} \times \text { Treat }_{m}+ \\
& \alpha_{2} \cdot G 2_{i}+\rho_{2} \cdot G 2_{i} \times \text { Treat }_{m}+ \\
& C_{m}^{\prime} \omega_{1}+D_{i}^{\prime} \omega_{2}+T_{t}^{\prime} \omega_{3}+\epsilon_{\text {imt }} .
\end{aligned}
$$

Of interest to us are coefficient estimates of $\beta_{1}$ and $\beta_{2}$, which represent the average effect of the attack on individuals belonging to group 1 and group 2, respectively. Further, in each specification, we also report estimated differences in the impacts of the terror attack on each group $\left(\beta_{2}-\beta_{1}\right)$ along with the p-value associated with the test: $H_{0}: \beta_{1}-\beta_{2}=0$; $H_{A}: \beta_{1}-\beta_{2} \neq 0$. All results can be found in Table 2 .

First looking at the impacts of the attack along the dimension of political orientation (panel (a), Table 2), for those who self-identify as right wing, the impact of the attack on social capital broadly, and institutional and interpersonal trust specifically, is $0.257,0.313$, and 0.136 standard deviations, respectively. The impacts with respect to social capital and institutional trust are statistically significant at conventional levels. For those who claim to be on the left wing of the political spectrum, the estimated effects stemming from the terror attack are 0.300, 0.309, and 0.252 standard deviations for social capital, institutional trust, and interpersonal trust, respectively. Like those on the right wing, results for social capital and institutional trust are statistically significant at conventional levels. Unlike the right wing, however, the impact on interpersonal trust for those on the left is highly statistically significant. When looking at the impact on one's engagement in social networks, the impact on those who identify as right wing is 0.193 standard deviations while the impact for those who identify as being on the left is 0.085 standard deviations. Further, only the impact on

\footnotetext{
${ }^{15}$ Note, estimating equation (5) does not include a constant term.
} 
social networks for the right wing is statistically significant at conventional levels. For both the right and the left, the impact of the terrorist attack on reciprocity and ethnic tolerance is statistically indistinguishable from zero. Lastly, differences in the estimated effects between the right and left wing are not statistically significant for the broad measure of social capital or any of the sub-components.

Next, we explore how the impact of the terrorist attack varies across the distribution of religiosity (panel (b), Table 2). In particular, we discretize the data into religious and nonreligious groups and again estimate (5). What becomes immediately apparent is that those who claim to be religious experience a 0.204 standard deviation increase in social capital given the attack, with the impacts across the various sub-components being statistically insignificant. On the other hand, those who claim to not be religious experience sizable effects from the terrorist attack to social capital broadly, as well as for institutional and interpersonal trust specifically. In particular, the impact on social capital is 0.316 standard deviations with this effect being highly statistically significant. For institutional and interpersonal trust, the impact stemming from the attack is 0.416 and 0.275 standard deviations with both of these estimates being statistically significant at conventional levels. However, and similar to previous dimensions of heterogeneity, we are unable to claim statistical significance in the estimated effects between religious and non-religious individuals across all dimensions of social capital.

In panel (c) of Table 2 we look at high versus low television watchers and find that both groups are affected by the terrorist attack, in a positive and statistically relevant sense, with respect to the broadest measure of social capital. The same holds true for institutional trust and interpersonal trust. Interestingly, those in the high hours of television watched group experienced an impact of 0.343 standard deviations increase in reciprocity, with this result being highly statistically significant. This is the only point in all of the analysis where the impact of the terrorist attack results in a measurable, statistically significant effect on reciprocity. Further, the estimated difference in the impact of the terror attack on reciprocity 
between high and low television watchers is also statistically significant at conventional levels.

Overall in Table 2, institutional and interpersonal trust continue to be the primary components driving the results found when looking at social capital broadly. Two interesting points are worth noting. First, those who watch more television experience a statistically significant, sizable impact of the terrorist attack on reciprocity. Second, those who claim to be non-religious tend to increase their trust, economically and statistically, in both institutions and interpersonally relative to those who claim to be religious. However, one should exercise caution when interpreting the heterogeneity analysis presented here. Specifically, the results are purely descriptive in nature since the various dimensions of heterogeneity may themselves have been affected by the terrorist attack. ${ }^{16}$

\section{Conclusion}

Acts of terrorism have increased dramatically over the previous two decades. The measurable costs of such events, related to physical capital and loss of life, are great in magnitude and relatively easy to quantify. However, the impact on a country's level of social capital is not so easily assessed. As such, we utilize the Charlie Hebdo attack, coupled with the staggered and random nature that respondents were interviewed for the 2014 wave of the European Social Survey, as a means of identifying the impact of terrorism on a country's level of social capital. Our results demonstrate that terrorism has a significant positive and causal effect on social capital. The effect seems to be driven by an increase in institutional trust, interpersonal trust, as well as engagement in social networks. Our results are consistent with the hypothesis of a "rally effect." In looking at the temporal dynamics, we find that the impact of terrorism on social capital is at its peak right after the terror attack, but quickly reverts to pre-attack levels.

\footnotetext{
${ }^{16}$ Additional heterogeneity analyses across various demographic and socioeconomic measures can be found in supplemental appendix section A.1. In this section we also explore differential effects among French respondents (e.g. born in France vs. not born in France) as well as how the effect varies conditional on one's proximity to the epicenter of the attack in Paris.
} 
Since the level of social capital is elevated in the immediate aftermath following a terrorist attack, the impacted country's government may consider addressing concerns about national security, homeland defense, and combating terrorism abroad by leveraging the increase in social capital as a means of winning support to carry out various prescriptive measures. Further, the impacted government may consider using the augmented level of social capital as a policy tool to recover the direct economic losses due to terrorism or raise requisite revenues needed to implement programs aimed at mitigating radicalization both at home and abroad. As noted by Helliwell et al. (2017), the effect of positive interventions to restore the economic damages due to terrorism is likely to be amplified due to an increase in the stock of social capital. In addition, the higher stock of social capital may also be useful in diffusing threats of future terrorist attacks since it is found that "social capital is positively associated with increased [emergency] preparedness and with increased concern about future terrorism events" (Hausman et al., 2007, p. 1073). Lastly, the increase in social capital following an attack can, perhaps, be used to mitigate post-terrorism popular uprisings and/or inter-ethnic group conflicts. 


\section{References}

Abadie, A., and Gardeazabal, J. (2003). The economic costs of conflict: A case study of the Basque Country. American Economic Review 93(1): 113-132.

Arrow, K. (1972). Gifts and exchanges. Philosophy and Public Affairs 1(4): 343-362.

Arvanitidis, P., Economou, A., and Kollias, E. (2016). Terrorism's effects on social capital in European countries. Public Choice 169(3-4): 231-250.

Australian Bureau of Statistics (2002). Social Capital and Social Well Being. ABS Discussion Paper.

Backus, M., Blake, T., Masterov, D. V., and Tadelis, S. (2017). Expectation, Disappointment, and Exit: Reference Point Formation in a Marketplace (No. w23022). National Bureau of Economic Research.

Bali, V. (2007). Terror and elections: Lessons from Spain. Electoral Studies 26(3): 669-687.

Blomberg, S. B., Hess, G. D., and Tan, D. Y. (2011). Terrorism and the economics of trust. Journal of Peace Research 48(3): 383-398.

Blomberg, S. B., Hess, G. D., and Weerapana, A. (2004). Economic conditions and terrorism. European Journal of Political Economy 20(2): 463-478.

Brehm, J., and Rahn, W. (1997). Individual-level evidence for the causes and consequences of social capital. American Journal of Political Science 41(3): 999-1023.

Chanley, V. A. (2002). Trust in government in the aftermath of 9/11: Determinants and consequences. Political Psychology 23(3): 469-483.

Coleman, J.S. (1988). Social capital in the creation of human capital. American Journal of Sociology 94: S95-S119.

Coleman, J.S. (1990). Foundations of social theory. Cambridge MA: Belknap Press.

Collins, R. (2004). Rituals of solidarity and security in the wake of terrorist attack. Sociological Theory 22(1): 53-87.

Durlauf, S.N. (2002). On the empirics of social capital. The Economic Journal 112: F459F479. 
Durlauf, S.N., and Fafchamps, M. (2005). Social Capital. In: Aghion, P., Durlauf, S.N. (Eds.), Handbook of Economic Growth, vol. 1A. Elsevier, Amsterdam.

Eckstein, Z., and Tsiddon, D. (2004). Macroeconomic consequences of terror: Theory and the case of Israel. Journal of Monetary Economics 51(5): 971-1002.

Forte, A., Peiro-Palominó, J., and Tortosa-Ausina, E. (2015). Does social capital matter for European regional growth. European Economic Review 77: 47-64.

Frey, B., Luechinger, S., and Stutzer, A. (2007). Calculating tragedy: assessing the costs of terrorism. Journal of Economic Surveys 21(1): 1-24.

Fukuyama, F. (1997). Social capital. Tanner lecture on human values.

Fukuyama, F. (1995). Trust: The Social Virtues and the Creation of Prosperity, London: Hamish Hamilton.

Gassebner, M., Jong-A-Pin, R., and Mierau, J. O. (2008). Terrorism and electoral accountability: One strike, you're out! Economics Letters 100(1): 126-129.

Glaeser, E.L., Laibson, D.I., Scheinkman, J.A., and Soutter, C.L. (2000). Measuring trust. Quarterly Journal of Economics 115(3): 811-846.

Glaeser, E.L., Laibson D.I., and Sacerdote, B. (2002). An economic approach to social capital. The Economic Journal 112: F437-F458.

Gould, E.D. and Esteban, K.F. (2016). The long-run effect of 9/11: Terrorism, backlash, and the assimilation of Muslim immigrants in the west. The Economic Journal 126: $2064-2114$

Gross, K., Aday, S., and Brewer, P. R. (2004). A panel study of media effects on political and social trust after September 11, 2001. The Harvard International Journal of Press/Politics 9(4): 49-73.

Halman, L., and Luijkx, R. (2006). Social capital in contemporary Europe. Portuguese Journal of Social Science 5(1): 65-90.

Hausman, A.J., Hanlon, A., and Seals, B. (2007). Social capital as a mediating factor in emergency preparedness and concerns about terrorism. Journal of Community Psychol- 
ogy 35(8): 1073-1083.

Helliwell, J., and Putnam, R.D. (1995). Economic growth and social capital in Italy. Eastern Economic Journal 21(3): 295-307.

Helliwell, J.F., Aknin, L.B., Shiplett, H., Huang, H., and Wang, S. (2017). Social capital and prosocial behaviour as sources of sell-being. (No. w23761). National Bureau of Economic Research.

Huddy, L., Feldman, S., Capelos, T., and Provost, C. (2002). The consequences of terrorism: Disentangling the effects of personal and national threat. Political Psychology 23(3): $485-509$.

Huddy, L., and Feldman, S. (2006). Personal threat, domestic security, and the erosion of civil liberties. Presented to the International Society of Political Psychology, Barcelona.

Kling, J.R., Liebman, J.B., and Katz, L.F. (2007). Experimental analysis of neighborhood effects. Quarterly Journal of Economics 75(1): 83-119.

Kim, D., and Kim, Y.A. (2017). Mental health cost of terrorism: Study of the Charlie Hebdo attack in Paris. Health Economics, forthcoming.

Knack, S., and Keefer, P. (1997). Does social capital have an economic impact? A crosscountry investigation. Quarterly Journal of Economics 112(4): 1252-1288.

LaPorta, R.L., Lopez-de-Salanes, F., Shleifer, A. and Vishny, R.W. (1997). Trust in large organisations. American Economic Review Papers and Proceedings 87(2): 333-338.

Metcalfe, R., Powdthavee, N. and Dolan, P. (2011) Destruction and distress: Using a quasiexperiment to show the effects of the September 11 attacks on mental well-being in the United Kingdom. The Economic Journal 121: F81-F103.

Montalvo, J. (2011). Voting after the bombings: A natural experiment on the effect of terrorist attacks on democratic elections. The Review of Economics and Statistics 93(4): $1146-1154$.

OECD (2011). The well-being of nations: The role of human and social capital. Paris: Organisation for Economic Cooperation and Development. 
Paxton, P. (2005). Trust in decline? Contexts 4(1): 40-45.

Perrin, A. J., and Smolek, S.J. (2009). Who trusts? Race, gender and the September 11 rally effect among young adults. Social Science Research 38(1): 134-145.

Putnam, R.D., Leonardi, R., and Nanetti, R.Y. (1993). Making Democracy Work: Civic Traditions in Modern Italy, Princeton: Princeton University Press.

Putnam, R. D. (2002). Bowling Alone: America's Declining Social Capital. Journal of Democracy 6(1): 65-78.

Putnam, R. D. (2002). Bowling together. The American Prospect 13(3): 20-22.

Sander, T. H., and Putnam, R. D. (2010). Still bowling alone? The post-9/11 split. Journal of Democracy 21(1): 9-16.

Sinclair, S., and LoCicero, A. (2010). Do fears of terrorism predict trust in government? Journal of Aggression, Conflict and Peace Research 2(1): 57-68.

Smith, V.K., Mansfield, C., and Clayton, L. (2009). Valuing a homeland security policy: Countermeasures for the threats of shoulder mounted missiles. Journal of Risk and Uncertainty 38(3): 215-243.

Tallman, M. (2007). Patriotism, or bread and circuses? A brief discussion of the SeptemberOctober 2001 rally 'round the flag effect. Critique: A Worldwide Journal of Politics $64-80$.

The Heritage Foundation (2016). Solutions 2016, The Heritage Foundation: Washington D.C.

The Institute for Economics \& Peace (2015). Global Terrorism Index 2015. New York: The Institute for Economics \& Peace.

Uslaner, E., Canetti-Nissim, D., and Pedahzur, A. (2004). Terrorism and trust: Sustained violence and the social fabric in Israel. Unpublished manuscript available through http://www.bsos.umd.edu/gvpt/uslaner/working.htm.

Woods, J. (2011). The 9/11 effect: Toward a social science of the terrorist threat. Social Science Journal 48(1): 213-233. 


\section{Tables}

Table 1: DID Estimates

\begin{tabular}{|c|c|c|c|c|c|c|}
\hline Dependent Variable: & $\begin{array}{l}\text { Social } \\
\text { Capital }\end{array}$ & $\begin{array}{c}\text { Institutional } \\
\text { Trust } \\
\end{array}$ & $\begin{array}{c}\text { Interpersonal } \\
\text { Trust } \\
\end{array}$ & $\begin{array}{c}\text { Social } \\
\text { Networks }\end{array}$ & Reciprocity & $\begin{array}{c}\text { Ethnic } \\
\text { Tolerance }\end{array}$ \\
\hline (A) [Full Sample] & $(1)$ & $(2)$ & (3) & (4) & $(5)$ & $(6)$ \\
\hline Treat $x$ Post & $\begin{array}{c}0.271 * * * \\
(0.073)\end{array}$ & $\begin{array}{c}0.311 * * * \\
(0.079)\end{array}$ & $\begin{array}{c}0.183 * * \\
(0.073)\end{array}$ & $\begin{array}{c}0.138 \\
(0.086)\end{array}$ & $\begin{array}{l}0.0595 \\
(0.082)\end{array}$ & $\begin{array}{l}0.0145 \\
(0.078)\end{array}$ \\
\hline Observations & 12,466 & 12,466 & 12,466 & 12,466 & 12,466 & 12,466 \\
\hline (B) [-47 days, 47 days] & $(1)$ & $(2)$ & (3) & $(4)$ & $(5)$ & $(6)$ \\
\hline Treat $\mathrm{x}$ Post & $\begin{array}{c}0.288^{* * * *} \\
(0.076)\end{array}$ & $\begin{array}{c}0.338 * * * \\
(0.081)\end{array}$ & $\begin{array}{c}0.222 * * * \\
(0.075)\end{array}$ & $\begin{array}{c}0.109 \\
(0.088)\end{array}$ & $\begin{array}{l}0.0637 \\
(0.084)\end{array}$ & $\begin{array}{c}0.00953 \\
(0.080)\end{array}$ \\
\hline Observations & 9,260 & 9,260 & 9,260 & 9,260 & 9,260 & 9,260 \\
\hline (C) [-30 days, 30 days $]$ & $(1)$ & $(2)$ & (3) & (4) & $(5)$ & (6) \\
\hline Treat $\mathrm{x}$ Post & $\begin{array}{c}0.272 * * * \\
(0.098)\end{array}$ & $\begin{array}{c}0.294 * * * \\
(0.101)\end{array}$ & $\begin{array}{c}0.229 * * \\
(0.096)\end{array}$ & $\begin{array}{c}0.120 \\
(0.105)\end{array}$ & $\begin{array}{l}0.0227 \\
(0.106)\end{array}$ & $\begin{array}{c}0.046 \\
(0.096)\end{array}$ \\
\hline Observations & 5,751 & 5,751 & 5,751 & 5,751 & 5,751 & 5,751 \\
\hline Country FE & $y$ & $y$ & $y$ & $y$ & $y$ & $y$ \\
\hline Demographic Controls & $y$ & $y$ & $y$ & $y$ & $y$ & $y$ \\
\hline Week FE & $y$ & $y$ & $y$ & $y$ & $y$ & $y$ \\
\hline Includes Bordering Countries & $y$ & $y$ & $y$ & $y$ & $y$ & $y$ \\
\hline Includes Non-Bordering Countries & $y$ & $y$ & $y$ & $y$ & $y$ & $y$ \\
\hline
\end{tabular}

Notes: $* * * \mathrm{p}<0.01, * * \mathrm{p}<0.05, * \mathrm{p}<0.1$. Robust (Huber-White) standard errors shown in parentheses. Columns (1) - (6) report coefficient estimates of the treatment group by post Charlie Hebdo interaction terms as specified in estimating equation (1). The social capital index of interest used on the left hand side of estimating equation (1) is reported in the column headings above the column numbers. The set of demographic controls include: Second-order polynomials in age and education (in years); a binary variable indicating if the respondent is female; and a set of categorical variables indicating the decile of the respondent's household's total net income. 
Table 2: Heterogeneity Analysis

\begin{tabular}{|c|c|c|c|c|c|c|}
\hline Dependent Variable: & $\begin{array}{c}\text { Social } \\
\text { Capital }\end{array}$ & $\begin{array}{c}\text { Institutional } \\
\text { Trust }\end{array}$ & $\begin{array}{c}\text { Interpersonal } \\
\text { Trust } \\
\end{array}$ & $\begin{array}{c}\text { Social } \\
\text { Networks }\end{array}$ & Reciprocity & $\begin{array}{c}\text { Ethnic } \\
\text { Tolerance }\end{array}$ \\
\hline (A) Political Orientation & $(1)$ & (2) & (3) & (4) & $(5)$ & $(6)$ \\
\hline Right Wing $\mathrm{x}$ Treat $\mathrm{x}$ Post & $\begin{array}{c}0.257 * * * \\
(0.0917)\end{array}$ & $\begin{array}{c}0.313 * * * \\
(0.0991)\end{array}$ & $\begin{array}{c}0.136 \\
(0.0933)\end{array}$ & $\begin{array}{l}0.193 * \\
(0.106)\end{array}$ & $\begin{array}{c}0.00970 \\
(0.103)\end{array}$ & $\begin{array}{l}0.0215 \\
(0.106)\end{array}$ \\
\hline Left Wing $\mathrm{x}$ Treat $\mathrm{x}$ Post & $\begin{array}{c}0.300 * * \\
(0.118)\end{array}$ & $\begin{array}{c}0.309 * * \\
(0.133)\end{array}$ & $\begin{array}{c}0.252 * * \\
(0.115)\end{array}$ & $\begin{array}{l}0.0847 \\
(0.155)\end{array}$ & $\begin{array}{c}0.156 \\
(0.128)\end{array}$ & $\begin{array}{l}-0.0382 \\
(0.0923)\end{array}$ \\
\hline Observations & 11,528 & 11,528 & 11,528 & 11,528 & 11,528 & 11,528 \\
\hline Difference of Coefficients & -0.043 & 0.004 & -0.116 & 0.109 & -0.147 & 0.060 \\
\hline P-Value & {$[0.770]$} & {$[0.978]$} & {$[0.422]$} & {$[0.557]$} & {$[0.363]$} & {$[0.663]$} \\
\hline (B) Religiosity & $(1)$ & (2) & (3) & (4) & $(5)$ & $(6)$ \\
\hline Religious $\mathrm{x}$ Treat $\mathrm{x}$ Post & $\begin{array}{l}0.204 * * \\
(0.0996)\end{array}$ & $\begin{array}{c}0.187 \\
(0.115)\end{array}$ & $\begin{array}{c}0.0938 \\
(0.0932)\end{array}$ & $\begin{array}{c}0.110 \\
(0.123)\end{array}$ & $\begin{array}{l}0.0708 \\
(0.112)\end{array}$ & $\begin{array}{l}0.0982 \\
(0.113)\end{array}$ \\
\hline Not Religious x Treat x Post & $\begin{array}{c}0.316^{* * * *} \\
(0.102)\end{array}$ & $\begin{array}{c}0.416^{* * * *} \\
(0.103)\end{array}$ & $\begin{array}{c}0.275^{* *} \\
(0.110)\end{array}$ & $\begin{array}{c}0.159 \\
(0.116)\end{array}$ & $\begin{array}{l}0.0271 \\
(0.118)\end{array}$ & $\begin{array}{l}-0.0861 \\
(0.0989)\end{array}$ \\
\hline Observations & 12,424 & 12,424 & 12,424 & 12,424 & 12,424 & 12,424 \\
\hline Difference of Coefficients & -0.112 & -0.229 & -0.181 & -0.049 & 0.044 & 0.184 \\
\hline P-Value & {$[0.423]$} & {$[0.131]$} & {$[0.198]$} & {$[0.769]$} & {$[0.785]$} & {$[0.208]$} \\
\hline (C) Television & $(1)$ & (2) & $(3)$ & (4) & $(5)$ & $(6)$ \\
\hline Hours Watched (High) x Treat x Post & $\begin{array}{c}0.376 * * * \\
(0.0930)\end{array}$ & $\begin{array}{c}0.388 * * * \\
(0.113)\end{array}$ & $\begin{array}{c}0.175^{*} \\
(0.0967)\end{array}$ & $\begin{array}{l}0.0252 \\
(0.117)\end{array}$ & $\begin{array}{c}0.343^{* * *} \\
(0.119)\end{array}$ & $\begin{array}{c}0.0653 \\
(0.0924)\end{array}$ \\
\hline Hours Watched (Low) x Treat x Post & $\begin{array}{l}0.193 * \\
(0.101)\end{array}$ & $\begin{array}{c}0.260 * * \\
(0.105)\end{array}$ & $\begin{array}{l}0.190 * \\
(0.101)\end{array}$ & $\begin{array}{l}0.213 * \\
(0.116)\end{array}$ & $\begin{array}{l}-0.146 \\
(0.106)\end{array}$ & $\begin{array}{c}-0.0305 \\
(0.111)\end{array}$ \\
\hline Observations & 12,454 & 12,454 & 12,454 & 12,454 & 12,454 & 12,454 \\
\hline Difference of Coefficients & 0.184 & 0.128 & -0.015 & -0.188 & 0.489 & 0.096 \\
\hline P-Value & [0.173] & [0.397] & [0.914] & [0.247] & [0.002] & {$[0.496]$} \\
\hline
\end{tabular}

Notes: $* * * \mathrm{p}<0.01, * * \mathrm{p}<0.05, * \mathrm{p}<0.1$. Robust (Huber-White) standard errors in parentheses. Columns (1) - (6) report coefficient estimates of the treatment group by post Charlie Hebdo interaction terms as specified in estimating equation (5) using the full sample of observations [-68 days, 47 days] and full sample of countries. Each model includes country fixed effects, week fixed effects, and demographic controls (second-order polynomials in age and education; a binary variable indicating if the respondent is female; and a set of categorical variables indicating the decile of the respondent's household's total net income). The social capital index of interest used on the left hand side of estimating equation (5) is reported in the column headings above the column numbers. The dimension of heterogeneity considered is given in each panel heading. 


\section{Figures}

\section{Figure 1: Trend Analysis}
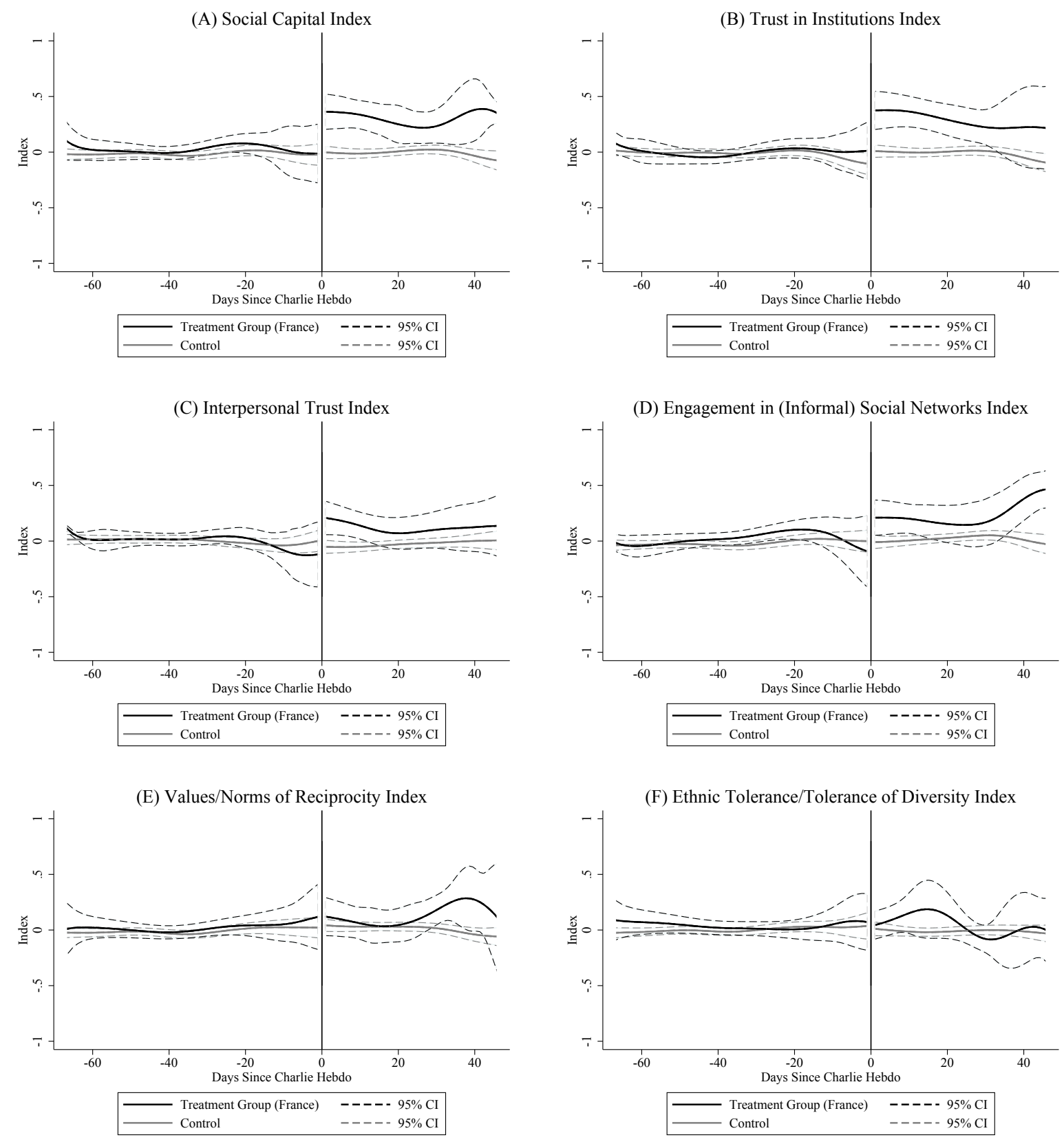


\section{Figure 2: Temporal Dynamics}

(A) Social Capital Index

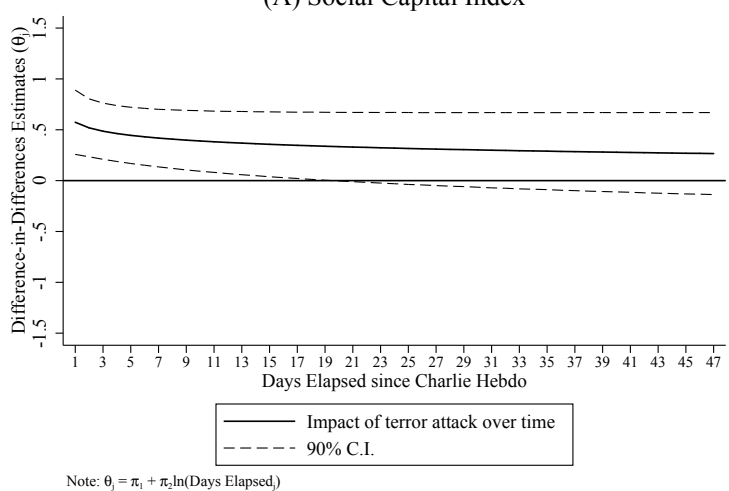

(C) Interpersonal Trust Index

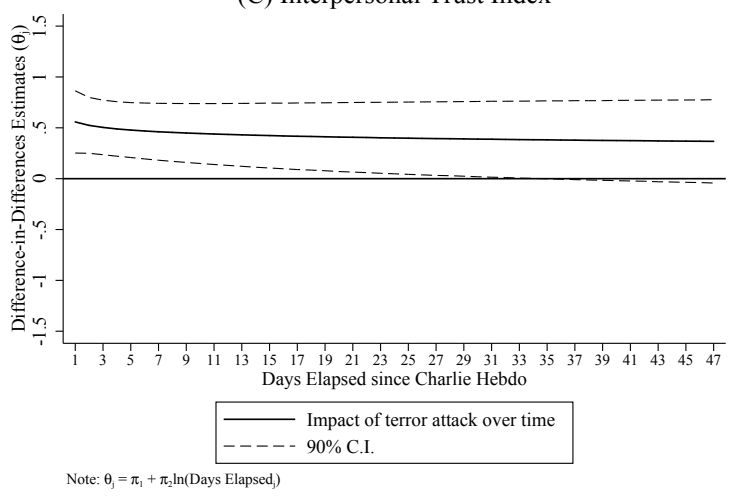

(E) Values/Norms of Reciprocity Index

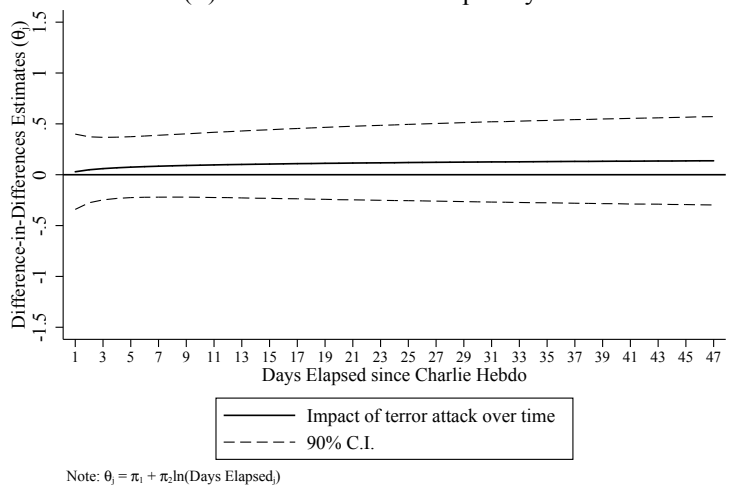

(B) Trust in Institutions Index

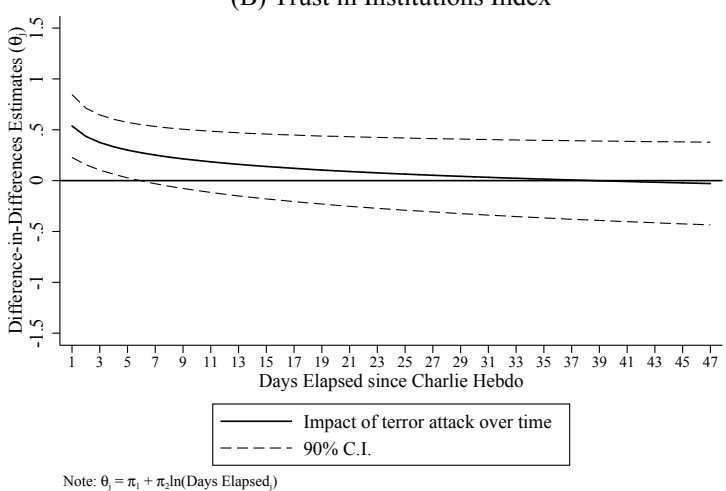

(D) Engagement in (Informal) Social Networks Index

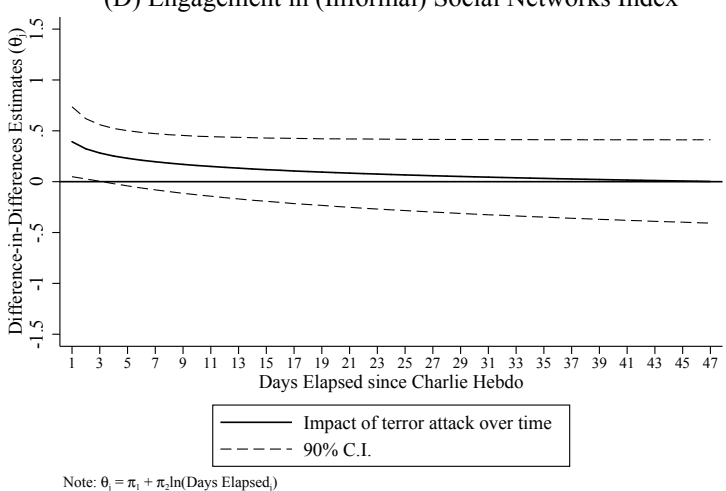

(F) Ethnic Tolerance/Tolerance of Diversity Index

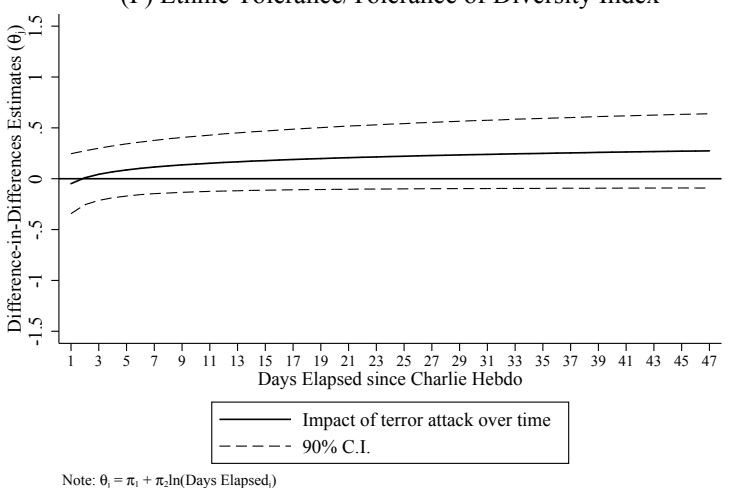




\section{Supplemental Appendix}

The Impact of Terrorism on Social Capital: Evidence from the $\mathbf{2 0 1 5}$

Charlie Hebdo Paris Shooting 


\section{Appendix A Supplemental Appendix}

Here we conduct additional heterogeneity analyses, rigorously explore threats to identification and robustness of our main results, discuss external validity, and reproduce the analysis using attitudes toward immigrants as the outcome of interest.

\section{A.1 Additional Heterogeneity Analyses}

Here we present additional dimensions of heterogeneity results that explore how the impact of the terrorist attack varies across multiple demographic and socioeconomic measures. For ease of exposition, we partition model estimates of equation 5 found in the main manuscript into two tables: Table A17 and Table A18. In Table A17 we consider gender (male vs. female), age (old vs. young), and education (high vs. low). In Table A18 we present results for marital status, employment status, and income. ${ }^{1}$ Each column of Tables A17 and Table A18 present model estimates of equation (5) from the main manuscript for social capital and each individual component of the index. As we did before, in each specification, we also report estimated differences in the impacts of the terror attack on each group $\left(\beta_{2}-\beta_{1}\right)$ along the the p-value associated with the test: $H_{0}: \beta_{1}-\beta_{2}=0 ; H_{A}: \beta_{1}-\beta_{2} \neq 0$.

We first present results pertaining to impacts across the dimensions of gender, age, and education (Table A17). Interestingly, we find statistically significant effects of the terrorist attack within groups for the broad measure of social capital and its various components, but find very few instances of statistically relevant results between groups. Specifically, we see that for both males and females (panel (a)), the impact of the terrorist attack on the broad measure of social capital is 0.255 and 0.280 standard deviations, respectively. The impact on the individual components of social capital including institutional trust and interpersonal trust are 0.330 and 0.192 standard deviations for males and 0.291 and 0.170 standard deviations for females. These effects are statistically significant at conventional

\footnotetext{
${ }^{1}$ We classify a respondent as "older" if said respondent lies above the median age in the data (median age $=47)$. We classify a respondent as "high income" if said respondent has an above median income level (respondents that report household total income in the 6th to 10th decile).
} 
levels. However, the estimated impacts on social networks, reciprocity, and ethnic tolerance are statistically insignificant for both males and females.

Turning our attention to panel (b) of Table A17, we present results exploring the impacts of the terror attack across the dimension of age. In particular, we define "older" as an age at or above the median age and "younger" as an age below the median. Looking first at the impact of the terrorist attack on social capital broadly, we find that the terrorist attack resulted in a 0.200 and 0.341 standard deviation increase for older and younger individuals, respectively, with these results being statistically significant at conventional levels. For the various sub-components of social capital, the impact of the shooting on institutional trust is 0.256 standard deviations for older individuals and 0.368 standard deviations for younger individuals. Again these estimated impacts are statistically significant at conventional levels. With respect to interpersonal trust, the impacts are 0.142 and 0.212 standard deviations for older and younger individuals, respectively. However, the estimated impact on interpersonal trust is only statistically significant for those classified as being younger. The same is true for social networks where the 0.227 standard deviation impact for younger individuals is statistically significant whereas the impact is near zero and statistically insignificant for individuals older than the median age. Lastly, the remaining impacts on reciprocity and ethnic tolerance are, for both age groups, approximately zero in magnitude and statistically insignificant at conventional levels.

In panel (c) of Table A17 we present results for high versus low levels of education where individuals with years of schooling at or above the median years of schooling are classified as "high" while those below this threshold are classified as "low." Focusing first on those classified as having high levels of education, the estimated impact of the terrorist attack on the overall measure of social capital and on the sub-components institutional and interpersonal trust are $0.262,0.353$, and 0.217 standard deviations, respectively. These results are statistically significant at conventional levels. Still focusing on highly educated individuals, the impact of the attack on the remaining sub-components of the broader social capital 
index are statistically insignificant. Turning attention to individuals with levels of education below the median, a similar pattern emerges. The estimated impacts on social capital, institutional trust, and interpersonal trust are $0.275,0.286,0.152$ standard deviations, respectively. However, unlike our results for more educated individuals, only the estimated effects on the broad measure of social capital and institutional trust are statistically relevant at conventional levels. The impacts on interpersonal trust, social networks, reciprocity, and ethnic tolerance are all statistically insignificant at conventional levels. The one point of interest, however, is that the estimated difference in the impact on reciprocity is statistically significant at conventional levels between high and low education attainers.

Overall in Table A17 it becomes apparent that institutional trust and interpersonal trust are the primary drivers for the results found when looking at our broad measure of social capital across the above dimensions of heterogeneity. The two exceptions are for the young and low income earners where the impact of the attack had a positive and statistically significant effect on one's engagement in social networks. Further, and as alluded to earlier, while there are statistically significant impacts within groups, there are only two statistically discernible differences between groups when exploring the impact of the terrorist attack along the dimensions of gender, age and education.

We next present results for the second set of heterogeneity analyses where we explore the impact of the terrorist attack along the dimensions of marital status, employment status, and income (high vs. low). Focusing first on those who are married versus not married (panel (a), Table A18), the impact of the attack on social capital is 0.220 and 0.332 standard deviations for married and not married, respectively. Both of these estimated effects are statistically significant at conventional levels. For institutional and interpersonal trust, the estimated effects from the attack are 0.306 and 0.146 standard deviations, respectively, with only the effect associated with institutional trust being statistically significant. For non-married individuals, the estimated impacts of the terrorist attack on institutional and interpersonal trust are 0.314 and 0.223 standard deviations, respectively; both of these im- 
pacts are statistically significant at conventional levels. With respect to the impact of the attack on social networks, only the impact on non-married individuals is statistically significant with the estimated magnitude being 0.178 standard deviations. For both married and non-married respondents, the impact of the attack on reciprocity and ethnic tolerance are statistically insignificant.

In panel (b) of Table A18 we explore how the impact of the terror attack varies across the distribution of employment status. The estimated impact of the attack for those classified as employed are $0.286,0.332$, and 0.200 standard deviations for social capital, institutional trust, and interpersonal trust, respectively. The same estimated impacts for those classified as unemployed are 0.248, 0.309, 0.164 standard deviations for social capital, institutional trust, and interpersonal trust, respectively. All of these estimated impacts, with the exception of interpersonal trust for unemployed individuals, are statistically significant at conventional levels. The estimated impact of the terrorist attack on the remaining subcomponents of social capital are statistically indistinguishable from zero for both employed and unemployed individuals.

Looking along the dimension of income reveals findings similar to those presented earlier (panel (c), Table A18). As before, we use the median level of this measure to demarcate between "high" versus "low" levels of income. For high income earners, the estimated impact of the attack on the overall measure of social capital is 0.223 standard deviations. For low income earners, the estimated impact on social capital is 0.345 standard deviations. Both of these are statistically significant at conventional levels. With respect to the impact of the terrorist attack on institutional and interpersonal trust, the estimated impacts on high income earners are 0.338 and 0.138 standard deviations, respectively. However, only the estimates related to institutional trust are statistically significant. For low income earners, the estimated impacts on institutional and interpersonal trust are 0.302 and 0.254 , respectively, with both of these impacts being statistically significant at conventional levels. Turning attention back to high income earners, the estimated effects on the remaining sub-components 
of social capital - social networks, reciprocity, and ethnic tolerance - are all statistically insignificant at conventional levels. The same pattern emerges for low income earners, but with one exception. Unlike high income earners, the terrorist attack induced a 0.271 standard deviation increase in engagement in social networks with this impact being statistically relevant at conventional levels. Interestingly, the estimated difference on ethnic tolerance is statistically significant between high and low income earners.

The results presented in Table 2 and Table A18 are similar to the results presented in Table 2 of the main manuscript in that institutional trust and interpersonal trust are the primary sub-components of social capital driving the results across the various dimensions of heterogeneity. However, what remains unclear is the extent to which there exists a uniform, upward shift in social capital across all of France or not. Along these lines, we pursue two additional dimensions of heterogeneity.

First, in Table A19 we test for a differential response to the attack between French respondents born in France and French respondents not born in France. Specifically, we report coefficient estimates of the treatment group by post Charlie Hebdo interaction term as specified in equation (1) found in the main manuscript defining the set of French respondents born in France as the treatment group (e.g. Born in France =1) and the set of French respondents not born in France as the control group (e.g. Born in France $=0$ ). These empirical results suggest that the change in social capital before and after the attack amongst individuals living in France who were born in France is not statistically different than the change in social capital among individuals living in France who were not born in France.

Second, we analyze how the effect of the attack varies with respect to one's proximity to the epicenter of the attack. To do this, we acquired spatial data on Level 2 Nomenclature of Territorial Units (NUTS) for 2016 from EUROSTAT; specifically, GIS shapefiles delineating the boundary of each region contained within France. Given the data, we compute the variable "Distance to Attack" that measures the geodesic distance from the centroid of each region to the latitude and longitude coordinates corresponding to the location of the 
Charlie Hebdo shooting. Given this variable, and restricting attention only to France, we estimate a difference-in-differences model with "Distance to Attack" as a continuous policy treatment. Specifically, we estimate our standard DID model replacing the variable "Treat" with "Distance to Attack". Of interest to us are coefficient estimates on "Distance to Attack" interacted with the post Charlie Hebdo indicator variable; these results are shown in Table A20. Inspection of Table A20 shows that across all model specifications and all dependent variables, coefficient estimates on "Distance to Attack $\times$ Post" are statistically insignificant. If the impact of the attack in France varied with respect to proximity to the attack we would expect these coefficients to be statistically significant. However, the estimated effects are not providing evidence that Charlie Hebdo led to a uniform shift in social capital across France.

\section{A.2 Threats to Identification and Robustness}

We proceed by discussing and assessing threats to the identifying assumptions of our model. In section A.2.1 we re-estimate our main model varying the control set of countries to be both bordering and non-bordering countries. We also assess the degree to which spillover effects are present. In section A.2.2 we explore alternative model specifications. In section A.2.3 we consider alternative approaches to obtaining standard errors for our coefficient estimates. To provide richer context to the magnitude of the estimated effects stemming from the Charlie Hebdo attack, in section A.2.4 we re-scale the estimated effects of Charlie Hebdo in terms of other model covariates. We conduct placebo tests in section A.2.5. Finally, section A.2.6 provides evidence from a regression discontinuity design.

\section{A.2.1 Border vs. Non-Border Countries and Spillovers}

In the preceding sections, we report our main results using all countries other than France

as controls. However, one might be concerned that the amount of publicity of the attack may have induced changes in the level of social capital in neighboring countries. Along these lines, in this section we we investigate the extent to which spatial spillovers exist. 
First, in Tables A5 to A10, for each social capital index, we investigate how our model estimates change in response to refining the definition of the control group. We report estimates for each social capital index separately in each table with column (3) reporting our main results summarized in Table 1 which use all countries other than France as the control group. For the sake of completeness, columns (1) and (2) test the sensitivity of our main results to the exclusion of demographic controls and week fixed effects. Column (4) replicates column (3) after excluding the set of non-bordering countries from the sample. Likewise, column (5) replicates column (3) after excluding the set of bordering countries from the sample.

Focusing first on panel (a) of Table A5, we see that the average impact of the terrorist attack ranges from a 0.359 to 0.271 standard deviation increase in our social capital index when using all of the control countries. The estimated impact falls slightly to 0.243 and 0.261 standard deviations when utilizing only control countries that share a border with France and using non-bordering countries as controls, respectively. Further, these results are all significant at the $1 \%$ level.

Turning our attention to panels (b) and (c) of Table A5, we see that the estimated impacts on our broad measure of social capital remain qualitatively similar across all specifications, both in terms of magnitude and statistical significance, when restricting our window of time to be -47 to 47 days and -30 to 30 days. In particular, the results range from an average increase in the social capital index of 0.371 to 0.263 standard deviations and 0.328 to 0.236 standard deviations for the windows of -47 to 47 days and -30 to 30 days, respectively.

Looking at the impact of the Charlie Hebdo attack on institutional trust (Table A6), and first focusing on panel (a), we see that the attack increased, on average, our standardized measure of institutional trust by $0.372,0.304$, and 0.311 , standard deviations across specifications (1), (2), and (3) respectively. When using only control countries bordering France, we find that the impact of the terror attack declines to 0.265 standard deviations. Lastly, when using only non-bordering countries as controls, the impact of the attack is 0.318 
standard deviations. These results are all significant at the $1 \%$ level. As with our broader measure of social capital, varying the window of time prior to and after the terror attack leads to qualitatively similar results across all sample definitions. Specifically, the impacts range from 0.384 to 0.309 standard deviations for the -47 to 47 days window and from 0.326 to 0.227 standard deviations for the -30 to 30 days window (panels (b) and (c), Table A6).

Looking next at the impact of the terror incident on interpersonal trust, when using the entire sample of time and all control countries (panel (a), Table A7) we find that the attack increased, on average, the index of interpersonal trust in the range of 0.244 to 0.173 standard deviations. When only including bordering control countries, the average impact on interpersonal trust falls to 0.153 standard deviations. When using only non-bordering countries as controls, the impact is estimated to be 0.188 standard deviations. Restricting the window of time to -47 to 47 days relative to the event, the average impact ranges from 0.273 to 0.212 standard deviations. Further restricting the window to -30 to 30 days relative to the attack yields similar results ranging from 0.275 to 0.210 standard deviations (panels (b) and (c), Table A7). All results pertaining to the impact on interpersonal trust are statistically significant at conventional levels.

In panel (a) of Table A8 which reports our results for engagement in informal social networks, the average impact of the attack ranged from 0.211 to 0.122 standard deviations (panel (a), Table A8). However, only the results found in columns (1) and (2) which exclude week fixed effects are statistically significant at conventional levels. Further, in varying the window, irrespective of the definition of the control group, we find further mixed evidence on the attacks effect. For example, in panel (b) of Table A8 we find that the model only including country fixed effects leads to a statistically meaningful average effect of 0.189 standard deviations (column (1)); results from the more robust specifications lose statistical significance. More specifically, the point estimates are still precisely identified, but the effects are attenuated sufficiently to erode statistical significance. When further restricting the window of time to 30 days before and after the attack, results across all specifications 
are statistically insignificant (panel (c), Table A8).

Similar to our main results using all countries other than France as controls, in exploring the consequence of the Charlie Hebdo attack on the standardized measures of reciprocity and tolerance, we still find no meaningful effect on either of these components of our broader social capital index irrespective of the sample definition. See Tables A9 and A10 for detailed results.

Collectively, these findings show that our model results are robust to varying the definition of the control group which provides evidence that the effects of Charlie Hebdo were confined to France. Next, we provide additional empirical tests for the presence of spatial spillovers by explicitly comparing the evolution of social capital in bordering countries to non-bordering countries. $^{2}$

To operationalize these tests, we first omit France from the sample. Second, we reestimate equation (1) from the main manuscript after replacing the variable Treat $_{m}$ with a binary variable set equal to one for the set of countries bordering France and zero otherwise. The results of this exercise, which are reported in Table A21, show that there does not exist any statistically significant change in social capital in bordering countries relative to nonbordering countries before and after Charlie Hebdo irrespective of the social capital index or sub-sample we consider. With that said, even in the event of spillovers occurring from France to the set of control countries, we would be, in effect, estimating a lower bound.

\section{A.2.2 Additional Robustness Checks}

Throughout the paper we estimate each model using all countries in the ESS; however, for three countries (Spain, Norway and Portugal) there exists data on respondents surveyed before the attack but not after. In Table A26, for each outcome of interest we re-estimate the most robust version of our empirical model (e.g. equation (1) with the full set of covariates

\footnotetext{
${ }^{2}$ As noted previously, countries in the data that share a border with France include Belgium, Switzerland, Germany, Spain, and Netherlands. Countries in the data that do not share a border with France include Austria, Czech Republic, Denmark, Finland, United Kingdom, Republic of Ireland, Norway, Portugal, Sweden, and Slovenia.
} 
specified in the sub-panel titled Baseline covariates and sample definitions of Table A26) after excluding data from Spain, Norway and Portugal from consideration. In addition, we report p-values for two-tailed tests of differences between each coefficient estimate reported in Table A26 and the corresponding set coefficient estimate obtained from estimates of equation (1) that includes Spain, Norway and Portugal. As shown in Table A26, model estimates are qualitatively unaffected to refining the set of control countries.

Next, in Table A27 we test the robustness of our empirical models to the inclusion of additional control variables. For each social capital index of interest, Table A27 reports coefficient estimates of the treatment group by post Charlie Hebdo interaction terms as specified in estimating equation (1) after including a more robust set of covariates including: a binary variable indicating if the respondent is married; categorical variables indicating the respondents placement on the left/right scale; a binary variable indicating if the respondent is a citizen, a binary variable indicating if the respondent is employed, a binary variable indicating if the respondent is religious, and categorical variables indicating the number of hours of television watched. For each measure of social capital and for every sub-sample, coefficient estimates are qualitatively unchanged following the inclusion of these additional controls. These findings provide further evidence that the assumption of unconfoundedness holds and that utilizing the Charlie Hebdo attack as a quasi-natural experiment is appropriate. Lastly, in Table A28 we test the robustness of our empirical models to the inclusion of country specific linear time trends. Like our previous robustness checks, p-values associated with the two-tailed tests for differences between coefficient estimates with and without the inclusion of these trends show that each set coefficient estimates are not statistically different from each other.

\section{A.2.3 Cluster-Robust Standard Errors}

Throughout the paper, statistical inference is conducted with robust, heteroskedasticityconsistent (e.g. Huber-White) standard errors. In Tables A29 and A30 we consider two 
alternative approaches to obtaining standard errors. Specifically, in Table A29 for our most robust empirical specification and for each measure of social capital, statistical inference is performed with standard errors clustered at the country level. In Table A30, standard errors are clustered at the level of country by pre/post. And finally, in Table A31, standard errors are clustered at the country by week level. At all levels of clustering, standard errors are generally smaller than the corresponding set of Huber-White robust standard errors used throughout the paper.

\section{A.2.4 Re-scaled Coefficient Estimates of Charlie Hebdo}

Here we re-scale model estimates of Treat $_{m} \times$ Post $_{t}$ from estimating equation (1) found in the main manuscript in terms other determinants of social capital; specifically, education and income. Assuming that the estimated effects related to education and income are in fact causal, the goal of the current exercise is to make clearer the impact of Charlie Hebdo on social capital by expressing how education and income would need to change in order to mimic the effects of the attack. For continuous regressors, the exercise is straightforward. In the particular case of education, one can simply divide the estimated effect of Charlie Hebdo by the relevant marginal effect associated with increasing education by one year. For binary regressors indicating deciles of income, we can express what proportion of the Charlie Hebdo effect can be captured by turning particular regressors on and off. Further, with a complete set of binary indicators capturing the income distribution, the re-scaled effects need to be interpreted with respect to the first decile of income (the base case).

Turning attention first to the effects of Charlie Hebdo re-scaled in terms of education, in the first row, column (1) of Table A32 we find an estimate of 6.624 . What this value suggests is that in order to reproduce the same effect on social capital that was induced by the Charlie Hebdo attack, education among individuals would have to be increased, on average, by roughly 6 years. Re-scaled effects of Charlie Hebdo in terms of changes in education for institutional and interpersonal trust are roughly 13 years and 5 years, respectively. All other 
effects re-scaled in terms of education can be found in Table A32.

Looking at the income variables, where each category represents a particular decile of income, we can get a sense for what proportion of the effect stemming from Charlie Hebdo can be approximated by average differences in social capital between those at the bottom of the income distribution relative to some higher level of income. For example, the estimated average difference in social capital between those at the bottom decile of the income distribution relative to those at the 70th percentile of the income distribution achieves, on average, approximately $98.8 \%$ of the estimated effect on social capital generated by the Charlie Hebdo attack. Looking at the highest decile, we see that the average difference in social capital between those at the lowest decile of the income distribution relative to those at the highest decile is equivalent to roughly $178.8 \%$ of the effect resulting from the Charlie Hebdo attack; almost two times the effect. In essence, the higher one climbs the income distribution, the magnitude of the disparities in average levels of social capital between these higher income groups and the bottom $10 \%$ of income earners is more than the induced rally effect achieved by the terrorist attack. The complete set of re-scaled effects across all deciles of income and across all components of social capital, relative to the bottom $10 \%$ of income earners, can be found in Table A32.

\section{A.2.5 Placebo Test - Timing of Event}

Next, in Table A33 we report the results of a placebo test whereby we modify the timing of the attack. To perform these tests, we first restrict attention to the pre-treatment time-period. Next, we split the sample in half with respect to time and test for any differential change in social capital in France relative to the set of controls. For example, restricting attention to the broadest pre-treatment window of -68 to -1 days, we generate an indicator variable, $I(-35 \text { Days, }-1 \text { Day })_{t}$, that is set equal to one for any respondent surveyed between -35 and -1 days of Charlie Hebdo. We then re-estimate equation (1) replacing the Post with $I(-35 \text { Days, }-1 \text { Day })_{t}$. We perform the same exercise restricting the pre-treatment window 
from -47 to -1 days and -30 to -1 days and report all estimated coefficients on the interaction terms of interest in Table A33

Inspecting Table A33 reveals that of the eighteen coefficient estimates reported, only one is statistically significant. Specifically, the coefficient estimate reported in column (2) of panel (a) is positive and marginally significant. This result implies is that relative to the set of controls, France experienced a small change in institutional trust in the 35 day window of time before Charlie Hebdo. However, in the smallest pre-treatment window of -30 to -1 days, we fail to detect any statistically significant effects. Recall that our formal estimates for differences in trends reported in Table A12 also fail to indicate any statistically significant difference in the overall trend in institutional trust among French respondents relative to respondents in all other countries, bordering countries, and/or non-bordering countries. These results, coupled with the placebo results associated with the -30 to -1 day window of time, provides additional evidence suggesting that the underlying parallel trends assumption holds within the 30 day window of time around the terrorist attack.

\section{A.2.6 Evidence from a Regression Discontinuity Approach}

In section A.2.1 we test for spatial spillovers due to Charlie Hebdo by contrasting bordering countries to non-bordering countries the results of which indicate that in relative terms, there does not exist any differential change in social capital between bordering and nonbordering countries. These findings lend credence to the validity of using countries other than France as a control group but do not necessarily rule out the possibility that our model estimates may be biased due to spillover effects stemming from both bordering and nonbordering countries responding to Charlie Hebdo. This might be particularly problematic for the interpretation of our estimates if, for instance, there was a decrease in social capital in all countries, but a little less in France. Before proceeding any further, we highlight here that our visual inspection of the data seem to suggest this is not the case. For every measure of social capital, Figure 1 found in the main manuscript fails to indicate any structural 
shift in social capital among the set of control countries immediately following the attack. In contrast, Figure 1 shows an immediate spike in social capital following the onset of the terrorist attack in France.

These descriptive results provide evidence that the effects of the terrorist attack on social capital were localized in France. We proceed by quantifying this immediate jump in social capital in France more formally using a regression discontinuity framework. To do this, we restrict attention to French respondents and estimate:

$$
\begin{aligned}
Z_{i t}= & \alpha_{1}+\rho_{1} \cdot \text { Days Since Event } \text { t }_{t} \times \text { Post }_{t} \\
& \rho_{2} \cdot \text { Days Since Event } t \\
& { }_{1} \cdot \text { Post }_{t}+D_{i}^{\prime} \omega+\epsilon_{i t} .
\end{aligned}
$$

Of interest to us are coefficient estimates of $\beta_{1}$, which capture the immediate shift in the average level of social capital among French respondents. Estimates obtained from equation (6), which are are reported in Table A22, indicate that immediate jumps in our broadest measure of social capital, institutional trust, and interpersonal trust, as shown in Figure 1 of the main manuscript, are also statistically relevant.

\section{A.3 External Validity and Extensions}

We highlight here that the 2015 Charlie Hebdo terrorist attack was not an attack on random people, but rather an attack against politically engaged journalists. As such, one might raise the concern is that our findings are not externally valid with respect to the impact of terrorist attacks on social capital more generally. Additionally, understanding how terrorism impacts attitudes towards immigrants is an interesting extension worth investigating

given the available data. As such, we perform three additional analyses using data on the December 2016 Berlin Christmas terrorist attack from the 2016 wave of the ESS (round 8), 
utilizing granular data on country-level terrorist attacks obtained from the Global Terrorism Database ${ }^{3}$ (GTD), and, lastly, using a measure of attitudes towards immigrants as an additional outcome of interest.

\section{A.3.1 December 2016 Berlin Christmas Attack}

On December 19, 2016 a truck/lorry was intentionally driven into the Breitscheidplatz Christmas market killing 12 people and injuring another 48 individuals. The attack was later claimed by the Islamic State (IS) terrorist group. Unlike the Charlie Hebdo attack in France, this attack was directed more towards the modal citizen and not necessarily towards those deemed politically active. Using only the eighth wave of the European Social Survey, we re-estimate equation (1) from the main manuscript where Treat $_{m}$ is now an indicator variable now set equal to one for any individual in our sample located in Germany, and zero otherwise. $^{4}$ As before, Post $t_{t}$ is an indicator variable set equal to one for any individual in our sample that was surveyed after the terror attack, $C_{m}^{\prime}$ is a set of country fixed effects, $T_{t}^{\prime}$ is a complete set of week fixed effects, and $D_{i}^{\prime}$ is the same set of demographic controls used in the Charlie Hebdo analysis. We again estimate estimate (1) multiple times using our broad measure of social capital, as well as the various components of social capital, as our outcome of interest. We further estimate the model multiple times varying the window of time around the Christmas attack with the full sample ranging from -112 days before the attack to 88 days after the attack. All results can be found in Table A24.

Inspecting Table A24 quickly reveals that in the case of the Berlin attack we do not detect any significant effects with respect to the impact of terrorism on social capital. Across all specifications the estimated impacts are statistically insignificant at conventional levels. Qualitatively similar results are found when looking across the individual sub-components of social capital.

\footnotetext{
${ }^{3}$ https://www.start.umd.edu/gtd/; last accessed on November 25, 2018.

${ }^{4}$ Control countries include Austria, Belgium, Switzerland, Czech Republic, Estonia, Spain, Finland, Netherlands, Norway, Poland, Portugal, Russia, Sweden, and Slovenia.
} 
It is worth noting that the December Berlin Christmas attack was the fourth major attack over the preceding six months, with these first three attacks resulting in 10 fatalities and 25 major injuries. ${ }^{5}$ Unlike the Charlie Hebdo attack in France, which resulted in the first terrorism-related casualty since 2013, attacks in Germany were arguably not surprising in nature if individuals were augmenting expectations using the history of recent terrorist attacks as reference-points. Using a similar line of reasoning as in Backus et al. (2017), but adapted to the current context, the longer a resident of a particular country goes without encountering an "abrupt" terrorist attack leads to greater responses on the margin with respect to social capital. As such, it is reasonable to think that the string of terror-related events in Germany prior to the Christmas attack could possibly induce individuals to make minimal, if any, adjustments on the margin given what is, perhaps, perceived as the new normal. We address this further and attempt to reconcile our findings in the section below.

\section{A.3.2 Global Terrorism Analysis}

The unique circumstances Germany faced in the period of time leading up to the Berlin Christmas Attack may lead one to doubt whether the empirical results we report for Germany could be interpreted as causal, or not. As a result, it is difficult to contrast our empirical findings for the Berlin Christmas attack with our empirical findings for the Charlie Hebdo attack. However, our study of Germany does motivate us to think more deeply regarding the degree to which the results we report for France are externally valid. Along these lines, we proceed by discussing the principal advantages, as well as the potential disadvantages, of using Charlie Hebdo as a quasi-experiment for drawing inferences regarding the broader socioeconomic impacts of terrorism at large.

There are many aspects of the Charlie Hebdo attack that motivate the appropriateness of the difference-in-differences methodology utilized in this study. Most notably, Charlie Hebdo was the first terrorist attack in the West by Islamic extremists only to then be followed by

${ }^{5}$ See https://www.bbc.com/news/world-europe-36882445; last accessed on November 25, 2018. 
the November 2015 Paris attacks, the Berlin 2016 attack, and the three 2017 London attacks, among others. Rare is the circumstance where we can visualize how social capital evolves over the period of time immediately preceding and following an attack. Further, given the magnitude by which terrorism impacts countries around the world, it is even more challenging to identify experimental settings where concerns regarding bias from other contemporaneous treatments are relatively minimal. Collectively, these observations inspire confidence in the capacity of the difference-in-differences framework to identify a causal relationship.

On the other hand, we also note that there are certain aspects of the Charlie Hebdo attack that may or may not be representative of the average terrorist attack. As noted earlier, Charlie Hebdo was not an attack against random people, but against a French weekly news magazine that made strong political statements. The reaction to this event was both massive in terms of media coverage and public rallies. One could also argue that Charlie Hebdo was highly symbolic in terms of the people who were killed. Further, following the attack the French government and president worked to both unify the nation and display a common sense of identity. For these reasons, even with the climate in France leading up to the "abrupt" attack being an ideal setting to identify the causal effect of terrorism on social capital, the effects that we measure might, nonetheless, work through idiosyncratic components of the Charlie Hebdo attack. Motivated by these observations, we advance an alternative model relating terrorism to social capital on a broader geographic and temporal scale. To draw inferences regarding the extent to which one may interpret our estimates of the Charlie Hebdo attack as externally valid, we subsequently contrast the results of this exercise with our estimates for Charlie Hebdo across each measure of social capital.

First, we create a country-level index of terrorism. To do this, we acquire data from the GTD, which includes information for over 180,000 terrorist incidents around the world. For each act of terrorism, the GTD records both the affected country as well as the year

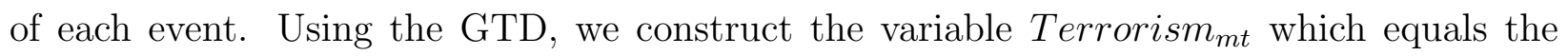
total number of fatalities due to terrorism in country $m$ in year $t$ standardized mean zero. 
Next, after stacking the seventh and the eighth waves ${ }^{6}$ of the European Social Survey, we assess the correlation between terrorism and social capital in the broader economy with the estimating equation,

$$
Z_{i m t}=\alpha+\beta \cdot \text { Terrorism } m_{m t}+C_{m}^{\prime} \omega_{1}+D_{i m}^{\prime} \omega_{2}+T_{t}^{\prime} \omega_{3}+\epsilon_{i m t}
$$

Here, $Z_{\text {imt }}$ represents our broad measure of social capital, as well as the various components of social capital. $C_{m}^{\prime}$ is a set of country fixed effects. $D_{i}^{\prime}$ is the suite of demographic control specified in section 4.1. $T_{t}^{\prime}$ is a vector of time-controls. In our baseline specification, $T_{t}^{\prime}$ represents a complete set of year fixed effects. In our robust specification, in addition to year fixed effects, we also includes a complete set of linear country-specific time trends to help control for other unobserved determinants of social capital varying through time within a country.

We present model estimates of estimating equation (7) in Table A25. Each column and panel of Table A25 represents the results of a variant estimating equation (7). The dependent variable used is indicated in each sub-panel heading. To gain a sense of the raw correlation between social capital and terrorism in the data, column (1) presents model estimates of equation (7) excluding all controls other than country specific

effects. Column (2) adds year fixed effects while column (3) adds demographic controls. Our robust specification is reported in column (4) which further adds country specific time trends.

Turning attention to column (1), with the exception of reciprocity, overall we observe that social capital and terrorism are positively correlated. Specifically, panel (a) suggests that a one standard deviation increase in the number of fatalities due to terrorism leads to a corresponding 0.018 standard deviation increase in our broadest measure of social capital.

\footnotetext{
${ }^{6}$ These data cover Austria, Belgium, Switzerland, Czech Republic, Germany, Denmark, Estonia, Spain, Finland, France, United Kingdom, Ireland, Lithuania, Netherlands, Norway, Poland, Portugal, Sweden, Slovenia for the years 2014, 2015, 2016. However, note that we do not have data for: Denmark in 2016; Estonia in 2014 or 2015; Lithuania in 2014 or 2016; Norway in 2015, Poland in 2014, Portugal in 2014.
} 
However, inspection of the results reported in panels (b) to (d) show that this effect is largely driven changes in institutional trust and interpersonal trust. As we move from column (1) to column (4) we observe that the raw correlations in the data as indicated by the model results reported in column (1) persist. In fact, point estimates for the impact of terrorism on social capital and institutional trust become larger in magnitude once we include a robust set of covariates. In no specification do we detect any statistically significant or economically meaningful relationship between terrorism and reciprocity.

Interpreting the results in column (4) as causal would require one to assume that once conditioned on country specific effects, demographics and time, terrorism is random. While we caution the reader in terms of interpreting the results reported in column (4) as causal, overall the results reported in Table A25 closely mirror our empirical estimates of the impacts of Charlie Hebdo attack. Although there does not exist a formal test of external validity, what we do find is that the findings we report for the Charlie Hebdo attack are consistent with the overall pattern between terrorism and social capital in the broader population of the European union.

\section{A.4 Attitudes towards Immigrants as an Outcome}

While not the primary focus of our paper, here we assess how the terrorist attack affected attitudes towards immigrants. In particular, the outcome of interest is now a standardized index capturing attitudes towards immigrants with higher index values corresponding to a more favorable view of immigrants. Specifically, the index is constructed from item responses related to the perceived role that immigrants have on culture, religion, crime, and the economy. The set of demographic controls are the same as in the analysis with social capital as the outcome of interest. We again estimate the model using the full sample, the restricted sample ranging from -47 to 47 days around the attack, and the time frame of -30 to 30 days around the attack. All results can be found in Table A23.

When looking at the results in Table A23 three findings emerge. First, when using all 
countries in the data, the estimated impact of the terrorist attack on attitudes towards immigrants ranges from 0.190 to 0.210 standard deviations in the most parsimonious specifications (panel (a), column (1), Table A23). These results are statistically significant at conventional levels.

Second, including demographic controls and week fixed effects reduces the magnitudes of these impacts to $0.126,0.147$, and 0.161 standard deviations for the full sample, -47 to 47 days sample, and -30 to 30 days sample, respectively. Further, only the point estimate associated with the -47 to 47 days sample remains statistically significant.

Third, when restricting attention to bordering countries as controls, model estimates attenuate even further and remain statistically insignificant. However, when restricting the sample to only include France and non-bordering countries, results are qualitatively similar to those found in specifications (1) through (3). Specifically, the estimated impacts of the attack on attitudes towards immigrants are $0.155,0.165$, and 0.164 across all windows of time with the estimated impacts being statistically significant at conventional levels for the full sample and the -47 to 47 days sample.

For the sake of completeness, we perform a similar exercise as we did with social capital and evaluate the impact of the attack in a regression discontinuity framework using time as the running variable. Results for this exercise are qualitatively similar to those presented above. However, a severe loss in precision is experienced given the loss of data when only using data associated with French respondents. As such no results presented are statistically significant at conventional levels. All results from this exercise can be found in appendix Table A34.

Overall it appears there is no clear effect of a terror-related attack on attitudes towards immigrants as measured by our index. However, in light of the imprecisely estimated coefficients, these null results should be interpreted with caution. It may very well be that terrorism does affect society's attitudes toward immigrants in a statistically meaningful way, and we are simply unable to draw such conclusions using this particular wave of the European 
Social Survey. 


\title{
Appendix Figures and Tables
}

\author{
Table A1: ESS Survey Questions Used to Construct Indices
}

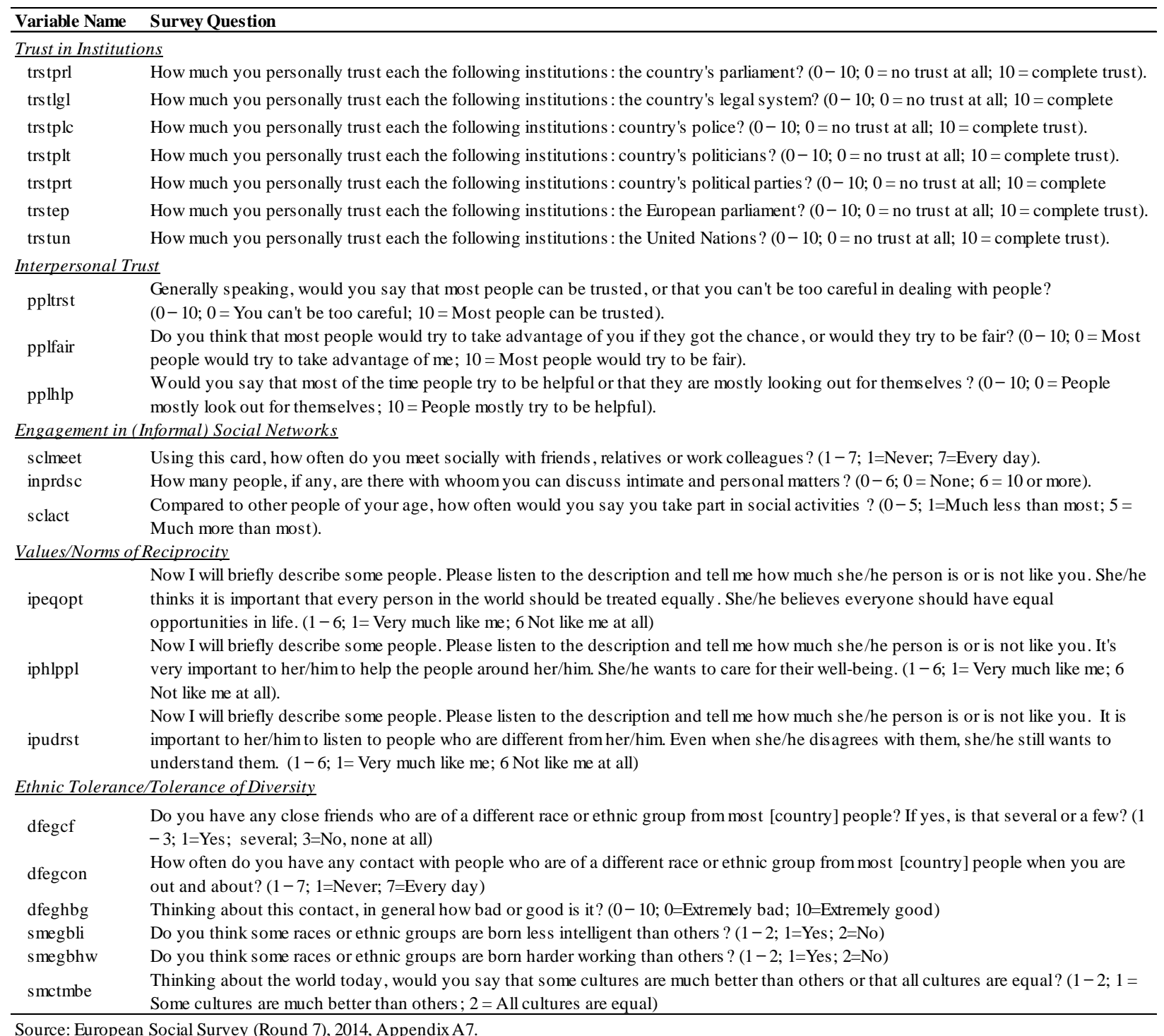

Source: European Social Survey (Round 7), 2014, Appendix A7. 
Table A2: Descriptive Statistics: France

\begin{tabular}{|c|c|c|c|c|c|c|c|c|c|}
\hline & (1) & (2) & (3) & (4) & (5) & (6) & (7) & (8) & (9) \\
\hline Sampling Window & \multicolumn{3}{|c|}{ Full Sample } & \multicolumn{3}{|c|}{ [-47 days, 47 days $]$} & \multicolumn{3}{|c|}{ [-30 days, 30 days $]$} \\
\hline Sampling Period & Pre & Post & Difference & Pre & Post & Difference & Pre & Post & Difference \\
\hline \multicolumn{10}{|l|}{ Outcome Variables } \\
\hline Social Capital & $\begin{array}{l}-0.036 \\
(0.033)\end{array}$ & $\begin{array}{c}0.334 \\
(0.061)\end{array}$ & $\begin{array}{c}0.370 \\
{[0.000]}\end{array}$ & $\begin{array}{l}-0.048 \\
(0.037)\end{array}$ & $\begin{array}{c}0.334 \\
(0.061)\end{array}$ & $\begin{array}{c}0.382 \\
{[0.000]}\end{array}$ & $\begin{array}{l}-0.002 \\
(0.067)\end{array}$ & $\begin{array}{c}0.322 \\
(0.065)\end{array}$ & $\begin{array}{c}0.324 \\
{[0.001]}\end{array}$ \\
\hline Institutional Trust & $\begin{array}{l}-0.029 \\
(0.031)\end{array}$ & $\begin{array}{c}0.338 \\
(0.067)\end{array}$ & $\begin{array}{c}0.367 \\
{[0.000]}\end{array}$ & $\begin{array}{l}-0.050 \\
(0.034)\end{array}$ & $\begin{array}{c}0.338 \\
(0.067)\end{array}$ & $\begin{array}{c}0.387 \\
{[0.000]}\end{array}$ & $\begin{array}{c}0.011 \\
(0.063)\end{array}$ & $\begin{array}{c}0.336 \\
(0.072)\end{array}$ & $\begin{array}{c}0.325 \\
{[0.001]}\end{array}$ \\
\hline Interpersonal Trust & $\begin{array}{l}-0.029 \\
(0.031)\end{array}$ & $\begin{array}{c}0.177 \\
(0.060)\end{array}$ & $\begin{array}{c}0.206 \\
{[0.002]}\end{array}$ & $\begin{array}{l}-0.043 \\
(0.033)\end{array}$ & $\begin{array}{c}0.177 \\
(0.060)\end{array}$ & $\begin{array}{c}0.220 \\
{[0.001]}\end{array}$ & $\begin{array}{l}-0.055 \\
(0.061)\end{array}$ & $\begin{array}{c}0.165 \\
(0.065)\end{array}$ & $\begin{array}{c}0.220 \\
{[0.014]}\end{array}$ \\
\hline Social Networks & $\begin{array}{l}-0.020 \\
(0.029)\end{array}$ & $\begin{array}{c}0.243 \\
(0.077)\end{array}$ & $\begin{array}{c}0.262 \\
{[0.002]}\end{array}$ & $\begin{array}{l}-0.004 \\
(0.033)\end{array}$ & $\begin{array}{c}0.243 \\
(0.077)\end{array}$ & $\begin{array}{c}0.247 \\
{[0.003]}\end{array}$ & $\begin{array}{c}0.028 \\
(0.059)\end{array}$ & $\begin{array}{c}0.245 \\
(0.081)\end{array}$ & $\begin{array}{c}0.217 \\
{[0.031]}\end{array}$ \\
\hline Reciprocity & $\begin{array}{l}-0.031 \\
(0.032)\end{array}$ & $\begin{array}{c}0.083 \\
(0.070)\end{array}$ & $\begin{array}{c}0.114 \\
{[0.142]}\end{array}$ & $\begin{array}{c}-0.034 \\
(0.037)\end{array}$ & $\begin{array}{c}0.083 \\
(0.070)\end{array}$ & $\begin{array}{c}0.117 \\
{[0.139]}\end{array}$ & $\begin{array}{c}0.022 \\
(0.065)\end{array}$ & $\begin{array}{c}0.059 \\
(0.075)\end{array}$ & $\begin{array}{c}0.037 \\
{[0.711]}\end{array}$ \\
\hline Tolerance & $\begin{array}{c}0.021 \\
(0.032)\end{array}$ & $\begin{array}{c}0.043 \\
(0.064)\end{array}$ & $\begin{array}{c}0.022 \\
{[0.759]}\end{array}$ & $\begin{array}{c}0.010 \\
(0.035)\end{array}$ & $\begin{array}{c}0.043 \\
(0.065)\end{array}$ & $\begin{array}{c}0.033 \\
{[0.655]}\end{array}$ & $\begin{array}{l}-0.011 \\
(0.055)\end{array}$ & $\begin{array}{c}0.046 \\
(0.069)\end{array}$ & $\begin{array}{c}0.057 \\
{[0.520]}\end{array}$ \\
\hline \multicolumn{10}{|l|}{ Covariates } \\
\hline Age & $\begin{array}{l}46.104 \\
(0.503)\end{array}$ & $\begin{array}{l}44.724 \\
(1.099)\end{array}$ & $\begin{array}{l}-1.381 \\
{[0.253]}\end{array}$ & $\begin{array}{l}46.047 \\
(0.548)\end{array}$ & $\begin{array}{l}44.724 \\
(1.099)\end{array}$ & $\begin{array}{l}-1.324 \\
{[0.281]}\end{array}$ & $\begin{array}{l}45.451 \\
(0.907)\end{array}$ & $\begin{array}{l}44.792 \\
(1.166)\end{array}$ & $\begin{array}{c}-0.659 \\
{[0.656]}\end{array}$ \\
\hline I(Male) & $\begin{array}{c}0.481 \\
(0.016)\end{array}$ & $\begin{array}{c}0.514 \\
(0.037)\end{array}$ & $\begin{array}{c}0.033 \\
{[0.417]}\end{array}$ & $\begin{array}{c}0.484 \\
(0.017)\end{array}$ & $\begin{array}{c}0.514 \\
(0.037)\end{array}$ & $\begin{array}{c}0.030 \\
{[0.470]}\end{array}$ & $\begin{array}{c}0.438 \\
(0.030)\end{array}$ & $\begin{array}{c}0.500 \\
(0.040)\end{array}$ & $\begin{array}{c}0.062 \\
{[0.214]}\end{array}$ \\
\hline Education & $\begin{array}{l}12.730 \\
(0.110)\end{array}$ & $\begin{array}{l}13.746 \\
(0.311)\end{array}$ & $\begin{array}{c}1.017 \\
{[0.002]}\end{array}$ & $\begin{array}{c}12.864 \\
(0.119)\end{array}$ & $\begin{array}{r}13.746 \\
(0.311)\end{array}$ & $\begin{array}{c}0.882 \\
{[0.008]}\end{array}$ & $\begin{array}{l}13.430 \\
(0.221)\end{array}$ & $\begin{array}{l}13.644 \\
(0.334)\end{array}$ & $\begin{array}{c}0.214 \\
{[0.593]}\end{array}$ \\
\hline \multicolumn{10}{|l|}{ HH Total Income } \\
\hline $\mathrm{I}\left(1^{\text {st }}\right.$ decile $)$ & $\begin{array}{c}0.081 \\
(0.007)\end{array}$ & $\begin{array}{c}0.079 \\
(0.015)\end{array}$ & $\begin{array}{c}-0.002 \\
{[0.888]}\end{array}$ & $\begin{array}{c}0.075 \\
(0.008)\end{array}$ & $\begin{array}{c}0.079 \\
(0.015)\end{array}$ & $\begin{array}{c}0.003 \\
{[0.837]}\end{array}$ & $\begin{array}{c}0.074 \\
(0.014)\end{array}$ & $\begin{array}{c}0.083 \\
(0.016)\end{array}$ & $\begin{array}{c}0.009 \\
{[0.683]}\end{array}$ \\
\hline $\mathrm{I}\left(2^{\text {nd }}\right.$ decile $)$ & $\begin{array}{c}0.102 \\
(0.009)\end{array}$ & $\begin{array}{c}0.077 \\
(0.019)\end{array}$ & $\begin{array}{c}-0.025 \\
{[0.244]}\end{array}$ & $\begin{array}{c}0.103 \\
(0.010)\end{array}$ & $\begin{array}{c}0.077 \\
(0.019)\end{array}$ & $\begin{array}{c}-0.025 \\
{[0.242]}\end{array}$ & $\begin{array}{c}0.105 \\
(0.017)\end{array}$ & $\begin{array}{c}0.081 \\
(0.021)\end{array}$ & $\begin{array}{c}-0.024 \\
{[0.378]}\end{array}$ \\
\hline $\mathrm{I}\left(3^{\text {rd }}\right.$ decile $)$ & $\begin{array}{c}0.078 \\
(0.008)\end{array}$ & $\begin{array}{c}0.059 \\
(0.014)\end{array}$ & $\begin{array}{c}-0.019 \\
{[0.239]}\end{array}$ & $\begin{array}{c}0.079 \\
(0.009)\end{array}$ & $\begin{array}{c}0.059 \\
(0.014)\end{array}$ & $\begin{array}{c}-0.020 \\
{[0.232]}\end{array}$ & $\begin{array}{c}0.086 \\
(0.016)\end{array}$ & $\begin{array}{c}0.057 \\
(0.015)\end{array}$ & $\begin{array}{c}-0.029 \\
{[0.185]}\end{array}$ \\
\hline $\mathrm{I}\left(4^{\text {th }}\right.$ decile $)$ & $\begin{array}{c}0.108 \\
(0.010)\end{array}$ & $\begin{array}{c}0.100 \\
(0.022)\end{array}$ & $\begin{array}{c}-0.008 \\
{[0.728]}\end{array}$ & $\begin{array}{c}0.111 \\
(0.011)\end{array}$ & $\begin{array}{c}0.100 \\
(0.022)\end{array}$ & $\begin{array}{c}-0.011 \\
{[0.641]}\end{array}$ & $\begin{array}{c}0.125 \\
(0.022)\end{array}$ & $\begin{array}{c}0.095 \\
(0.024)\end{array}$ & $\begin{array}{c}-0.030 \\
{[0.349]}\end{array}$ \\
\hline $\mathrm{I}\left(5^{\text {th }}\right.$ decile $)$ & $\begin{array}{c}0.102 \\
(0.010)\end{array}$ & $\begin{array}{c}0.095 \\
(0.022)\end{array}$ & $\begin{array}{c}-0.007 \\
{[0.777]}\end{array}$ & $\begin{array}{c}0.097 \\
(0.010)\end{array}$ & $\begin{array}{c}0.095 \\
(0.022)\end{array}$ & $\begin{array}{c}-0.002 \\
{[0.930]}\end{array}$ & $\begin{array}{c}0.106 \\
(0.020)\end{array}$ & $\begin{array}{c}0.100 \\
(0.024)\end{array}$ & $\begin{array}{c}-0.006 \\
{[0.847]}\end{array}$ \\
\hline $\mathrm{I}\left(6^{\text {th }}\right.$ decile $)$ & $\begin{array}{c}0.109 \\
(0.010)\end{array}$ & $\begin{array}{c}0.072 \\
(0.019)\end{array}$ & $\begin{array}{l}-0.037 \\
{[0.089]}\end{array}$ & $\begin{array}{c}0.106 \\
(0.011)\end{array}$ & $\begin{array}{c}0.072 \\
(0.019)\end{array}$ & $\begin{array}{l}-0.034 \\
{[0.122]}\end{array}$ & $\begin{array}{c}0.102 \\
(0.019)\end{array}$ & $\begin{array}{c}0.072 \\
(0.020)\end{array}$ & $\begin{array}{l}-0.030 \\
{[0.273]}\end{array}$ \\
\hline $\mathrm{I}\left(7^{\text {th }}\right.$ decile $)$ & $\begin{array}{c}0.151 \\
(0.012)\end{array}$ & $\begin{array}{c}0.144 \\
(0.028)\end{array}$ & $\begin{array}{l}-0.007 \\
{[0.820]}\end{array}$ & $\begin{array}{c}0.146 \\
(0.013)\end{array}$ & $\begin{array}{c}0.144 \\
(0.028)\end{array}$ & $\begin{array}{c}-0.002 \\
{[0.959]}\end{array}$ & $\begin{array}{c}0.117 \\
(0.019)\end{array}$ & $\begin{array}{c}0.143 \\
(0.029)\end{array}$ & $\begin{array}{c}0.025 \\
{[0.466]}\end{array}$ \\
\hline $\mathrm{I}\left(8^{\text {th }}\right.$ decile $)$ & $\begin{array}{c}0.114 \\
(0.011)\end{array}$ & $\begin{array}{c}0.113 \\
(0.025)\end{array}$ & $\begin{array}{c}-0.001 \\
{[0.973]}\end{array}$ & $\begin{array}{c}0.119 \\
(0.012)\end{array}$ & $\begin{array}{c}0.113 \\
(0.025)\end{array}$ & $\begin{array}{c}-0.005 \\
{[0.848]}\end{array}$ & $\begin{array}{c}0.116 \\
(0.020)\end{array}$ & $\begin{array}{c}0.108 \\
(0.026)\end{array}$ & $\begin{array}{c}-0.008 \\
{[0.804]}\end{array}$ \\
\hline $\mathrm{I}\left(9^{\text {th }}\right.$ decile $)$ & $\begin{array}{c}0.094 \\
(0.010)\end{array}$ & $\begin{array}{c}0.115 \\
(0.025)\end{array}$ & $\begin{array}{c}0.021 \\
{[0.435]}\end{array}$ & $\begin{array}{c}0.099 \\
(0.011)\end{array}$ & $\begin{array}{c}0.115 \\
(0.025)\end{array}$ & $\begin{array}{c}0.017 \\
{[0.541]}\end{array}$ & $\begin{array}{c}0.096 \\
(0.020)\end{array}$ & $\begin{array}{c}0.128 \\
(0.027)\end{array}$ & $\begin{array}{c}0.031 \\
{[0.355]}\end{array}$ \\
\hline $\mathrm{I}\left(10^{\text {th }}\right.$ decile $)$ & $\begin{array}{c}0.060 \\
(0.007)\end{array}$ & $\begin{array}{c}0.145 \\
(0.027)\end{array}$ & $\begin{array}{c}0.085 \\
{[0.002]}\end{array}$ & $\begin{array}{c}0.065 \\
(0.008)\end{array}$ & $\begin{array}{c}0.145 \\
(0.027)\end{array}$ & $\begin{array}{c}0.080 \\
{[0.005]}\end{array}$ & $\begin{array}{c}0.073 \\
(0.014)\end{array}$ & $\begin{array}{c}0.135 \\
(0.028)\end{array}$ & $\begin{array}{c}0.062 \\
{[0.052]}\end{array}$ \\
\hline Observations & 1,493 & 272 & - & 1,232 & 272 & - & 406 & 241 & - \\
\hline
\end{tabular}


Table A3: Descriptive Statistics: Bordering Countries

\begin{tabular}{|c|c|c|c|c|c|c|c|c|c|}
\hline & (1) & (2) & (3) & (4) & (5) & (6) & (7) & (8) & (9) \\
\hline Sampling Window & \multicolumn{3}{|c|}{ Full Sample } & \multicolumn{3}{|c|}{ [-47 days, 47 days $]$} & \multicolumn{3}{|c|}{ [-30 days, 30 days $]$} \\
\hline Sampling Period & Pre & Post & Difference & Pre & Post & Difference & Pre & Post & Difference \\
\hline \multicolumn{10}{|l|}{ Outcome Variables } \\
\hline Social Capital & $\begin{array}{l}-0.009 \\
(0.020)\end{array}$ & $\begin{array}{c}0.047 \\
(0.023)\end{array}$ & $\begin{array}{c}0.055 \\
{[0.071]}\end{array}$ & $\begin{array}{c}0.001 \\
(0.026)\end{array}$ & $\begin{array}{c}0.047 \\
(0.023)\end{array}$ & $\begin{array}{c}0.045 \\
{[0.192]}\end{array}$ & $\begin{array}{l}-0.011 \\
(0.037)\end{array}$ & $\begin{array}{c}0.051 \\
(0.027)\end{array}$ & $\begin{array}{c}0.062 \\
{[0.176]}\end{array}$ \\
\hline Institutional Trust & $\begin{array}{l}-0.003 \\
(0.020)\end{array}$ & $\begin{array}{c}0.027 \\
(0.024)\end{array}$ & $\begin{array}{c}0.030 \\
{[0.336]}\end{array}$ & $\begin{array}{c}0.008 \\
(0.025)\end{array}$ & $\begin{array}{c}0.027 \\
(0.024)\end{array}$ & $\begin{array}{c}0.019 \\
{[0.584]}\end{array}$ & $\begin{array}{c}0.003 \\
(0.035)\end{array}$ & $\begin{array}{c}0.046 \\
(0.028)\end{array}$ & $\begin{array}{c}0.043 \\
{[0.338]}\end{array}$ \\
\hline Interpersonal Trust & $\begin{array}{c}0.013 \\
(0.020)\end{array}$ & $\begin{array}{c}0.037 \\
(0.023)\end{array}$ & $\begin{array}{c}0.024 \\
{[0.424]}\end{array}$ & $\begin{array}{c}0.030 \\
(0.026)\end{array}$ & $\begin{array}{c}0.037 \\
(0.023)\end{array}$ & $\begin{array}{c}0.007 \\
{[0.847]}\end{array}$ & $\begin{array}{l}-0.005 \\
(0.037)\end{array}$ & $\begin{array}{c}0.029 \\
(0.027)\end{array}$ & $\begin{array}{c}0.034 \\
{[0.452]}\end{array}$ \\
\hline Social Networks & $\begin{array}{l}-0.009 \\
(0.020)\end{array}$ & $\begin{array}{c}0.022 \\
(0.023)\end{array}$ & $\begin{array}{c}0.031 \\
{[0.315]}\end{array}$ & $\begin{array}{l}-0.022 \\
(0.026)\end{array}$ & $\begin{array}{c}0.022 \\
(0.023)\end{array}$ & $\begin{array}{c}0.044 \\
{[0.206]}\end{array}$ & $\begin{array}{c}0.027 \\
(0.037)\end{array}$ & $\begin{array}{c}0.020 \\
(0.027)\end{array}$ & $\begin{array}{l}-0.007 \\
{[0.885]}\end{array}$ \\
\hline Reciprocity & $\begin{array}{l}-0.009 \\
(0.020)\end{array}$ & $\begin{array}{c}0.013 \\
(0.024)\end{array}$ & $\begin{array}{c}0.021 \\
{[0.491]}\end{array}$ & $\begin{array}{l}-0.009 \\
(0.026)\end{array}$ & $\begin{array}{c}0.013 \\
(0.024)\end{array}$ & $\begin{array}{c}0.022 \\
{[0.541]}\end{array}$ & $\begin{array}{l}-0.049 \\
(0.039)\end{array}$ & $\begin{array}{c}0.023 \\
(0.028)\end{array}$ & $\begin{array}{c}0.071 \\
{[0.134]}\end{array}$ \\
\hline Tolerance & $\begin{array}{l}-0.021 \\
(0.018)\end{array}$ & $\begin{array}{c}0.030 \\
(0.023)\end{array}$ & $\begin{array}{c}0.051 \\
{[0.087]}\end{array}$ & $\begin{array}{l}-0.010 \\
(0.024)\end{array}$ & $\begin{array}{c}0.030 \\
(0.023)\end{array}$ & $\begin{array}{c}0.039 \\
{[0.237]}\end{array}$ & $\begin{array}{l}-0.006 \\
(0.033)\end{array}$ & $\begin{array}{c}0.021 \\
(0.027)\end{array}$ & $\begin{array}{c}0.027 \\
{[0.528]}\end{array}$ \\
\hline \multicolumn{10}{|l|}{ Covariates } \\
\hline Age & $\begin{array}{l}48.793 \\
(0.358)\end{array}$ & $\begin{array}{l}48.279 \\
(0.420)\end{array}$ & $\begin{array}{c}-0.515 \\
{[0.351]}\end{array}$ & $\begin{array}{l}48.066 \\
(0.457)\end{array}$ & $\begin{array}{l}48.279 \\
(0.420)\end{array}$ & $\begin{array}{c}0.213 \\
{[0.732]}\end{array}$ & $\begin{array}{l}47.803 \\
(0.633)\end{array}$ & $\begin{array}{l}48.276 \\
(0.493)\end{array}$ & $\begin{array}{c}0.474 \\
{[0.555]}\end{array}$ \\
\hline I(Male) & $\begin{array}{c}0.478 \\
(0.010)\end{array}$ & $\begin{array}{c}0.516 \\
(0.012)\end{array}$ & $\begin{array}{c}0.038 \\
{[0.017]}\end{array}$ & $\begin{array}{c}0.481 \\
(0.013)\end{array}$ & $\begin{array}{c}0.516 \\
(0.012)\end{array}$ & $\begin{array}{c}0.035 \\
{[0.051]}\end{array}$ & $\begin{array}{c}0.507 \\
(0.018)\end{array}$ & $\begin{array}{c}0.517 \\
(0.014)\end{array}$ & $\begin{array}{c}0.010 \\
{[0.659]}\end{array}$ \\
\hline Education & $\begin{array}{l}13.681 \\
(0.073)\end{array}$ & $\begin{array}{l}13.338 \\
(0.125)\end{array}$ & $\begin{array}{c}-0.343 \\
{[0.018]}\end{array}$ & $\begin{array}{l}13.699 \\
(0.094)\end{array}$ & $\begin{array}{l}13.338 \\
(0.125)\end{array}$ & $\begin{array}{c}-0.360 \\
{[0.021]}\end{array}$ & $\begin{array}{l}13.631 \\
(0.133)\end{array}$ & $\begin{array}{l}13.248 \\
(0.136)\end{array}$ & $\begin{array}{c}-0.384 \\
{[0.044]}\end{array}$ \\
\hline \multicolumn{10}{|l|}{ HH Total Income } \\
\hline $\mathrm{I}\left(1^{\text {st }}\right.$ decile $)$ & $\begin{array}{c}0.055 \\
(0.004)\end{array}$ & $\begin{array}{c}0.087 \\
(0.007)\end{array}$ & $\begin{array}{c}0.032 \\
{[0.000]}\end{array}$ & $\begin{array}{c}0.057 \\
(0.006)\end{array}$ & $\begin{array}{c}0.087 \\
(0.007)\end{array}$ & $\begin{array}{c}0.030 \\
{[0.001]}\end{array}$ & $\begin{array}{c}0.056 \\
(0.008)\end{array}$ & $\begin{array}{c}0.091 \\
(0.008)\end{array}$ & $\begin{array}{c}0.034 \\
{[0.003]}\end{array}$ \\
\hline $\mathrm{I}\left(2^{\text {nd }}\right.$ decile $)$ & $\begin{array}{c}0.073 \\
(0.005)\end{array}$ & $\begin{array}{c}0.096 \\
(0.007)\end{array}$ & $\begin{array}{c}0.023 \\
{[0.009]}\end{array}$ & $\begin{array}{c}0.074 \\
(0.007)\end{array}$ & $\begin{array}{c}0.096 \\
(0.007)\end{array}$ & $\begin{array}{c}0.022 \\
{[0.023]}\end{array}$ & $\begin{array}{c}0.077 \\
(0.010)\end{array}$ & $\begin{array}{c}0.091 \\
(0.008)\end{array}$ & $\begin{array}{c}0.015 \\
{[0.252]}\end{array}$ \\
\hline $\mathrm{I}\left(3^{\text {rd }}\right.$ decile $)$ & $\begin{array}{c}0.094 \\
(0.006)\end{array}$ & $\begin{array}{c}0.140 \\
(0.008)\end{array}$ & $\begin{array}{c}0.046 \\
{[0.000]}\end{array}$ & $\begin{array}{c}0.099 \\
(0.008)\end{array}$ & $\begin{array}{c}0.140 \\
(0.008)\end{array}$ & $\begin{array}{c}0.040 \\
{[0.000]}\end{array}$ & $\begin{array}{c}0.088 \\
(0.010)\end{array}$ & $\begin{array}{c}0.135 \\
(0.010)\end{array}$ & $\begin{array}{c}0.047 \\
{[0.001]}\end{array}$ \\
\hline $\mathrm{I}\left(4^{\text {th }}\right.$ decile $)$ & $\begin{array}{c}0.096 \\
(0.006)\end{array}$ & $\begin{array}{c}0.120 \\
(0.008)\end{array}$ & $\begin{array}{c}0.024 \\
{[0.015]}\end{array}$ & $\begin{array}{c}0.094 \\
(0.008)\end{array}$ & $\begin{array}{c}0.120 \\
(0.008)\end{array}$ & $\begin{array}{c}0.026 \\
{[0.018]}\end{array}$ & $\begin{array}{c}0.098 \\
(0.011)\end{array}$ & $\begin{array}{c}0.115 \\
(0.009)\end{array}$ & $\begin{array}{c}0.017 \\
{[0.238]}\end{array}$ \\
\hline $\mathrm{I}\left(5^{\text {th }}\right.$ decile $)$ & $\begin{array}{c}0.090 \\
(0.006)\end{array}$ & $\begin{array}{c}0.107 \\
(0.008)\end{array}$ & $\begin{array}{c}0.017 \\
{[0.075]}\end{array}$ & $\begin{array}{c}0.091 \\
(0.007)\end{array}$ & $\begin{array}{c}0.107 \\
(0.008)\end{array}$ & $\begin{array}{c}0.015 \\
{[0.145]}\end{array}$ & $\begin{array}{c}0.097 \\
(0.011)\end{array}$ & $\begin{array}{c}0.100 \\
(0.009)\end{array}$ & $\begin{array}{c}0.003 \\
{[0.828]}\end{array}$ \\
\hline $\mathrm{I}\left(6^{\text {th }}\right.$ decile $)$ & $\begin{array}{c}0.115 \\
(0.006)\end{array}$ & $\begin{array}{c}0.108 \\
(0.008)\end{array}$ & $\begin{array}{l}-0.007 \\
{[0.462]}\end{array}$ & $\begin{array}{c}0.106 \\
(0.008)\end{array}$ & $\begin{array}{c}0.108 \\
(0.008)\end{array}$ & $\begin{array}{c}0.002 \\
{[0.870]}\end{array}$ & $\begin{array}{c}0.130 \\
(0.012)\end{array}$ & $\begin{array}{c}0.105 \\
(0.009)\end{array}$ & $\begin{array}{l}-0.025 \\
{[0.099]}\end{array}$ \\
\hline $\mathrm{I}\left(7^{\text {th }}\right.$ decile $)$ & $\begin{array}{c}0.131 \\
(0.007)\end{array}$ & $\begin{array}{c}0.076 \\
(0.006)\end{array}$ & $\begin{array}{l}-0.056 \\
{[0.000]}\end{array}$ & $\begin{array}{c}0.128 \\
(0.009)\end{array}$ & $\begin{array}{c}0.076 \\
(0.006)\end{array}$ & $\begin{array}{c}-0.053 \\
{[0.000]}\end{array}$ & $\begin{array}{c}0.119 \\
(0.012)\end{array}$ & $\begin{array}{c}0.087 \\
(0.008)\end{array}$ & $\begin{array}{l}-0.031 \\
{[0.031]}\end{array}$ \\
\hline $\mathrm{I}\left(8^{\text {th }}\right.$ decile $)$ & $\begin{array}{c}0.119 \\
(0.007)\end{array}$ & $\begin{array}{c}0.088 \\
(0.007)\end{array}$ & $\begin{array}{c}-0.031 \\
{[0.001]}\end{array}$ & $\begin{array}{c}0.113 \\
(0.008)\end{array}$ & $\begin{array}{c}0.088 \\
(0.007)\end{array}$ & $\begin{array}{c}-0.025 \\
{[0.021]}\end{array}$ & $\begin{array}{c}0.104 \\
(0.011)\end{array}$ & $\begin{array}{c}0.092 \\
(0.008)\end{array}$ & $\begin{array}{c}-0.012 \\
{[0.385]}\end{array}$ \\
\hline $\mathrm{I}\left(9^{\text {th }}\right.$ decile $)$ & $\begin{array}{c}0.111 \\
(0.007)\end{array}$ & $\begin{array}{c}0.093 \\
(0.007)\end{array}$ & $\begin{array}{c}-0.018 \\
{[0.061]}\end{array}$ & $\begin{array}{c}0.112 \\
(0.008)\end{array}$ & $\begin{array}{c}0.093 \\
(0.007)\end{array}$ & $\begin{array}{c}-0.019 \\
{[0.095]}\end{array}$ & $\begin{array}{c}0.107 \\
(0.012)\end{array}$ & $\begin{array}{c}0.095 \\
(0.009)\end{array}$ & $\begin{array}{c}-0.012 \\
{[0.409]}\end{array}$ \\
\hline $\mathrm{I}\left(10^{\text {th }}\right.$ decile $)$ & $\begin{array}{c}0.115 \\
(0.007)\end{array}$ & $\begin{array}{c}0.085 \\
(0.007)\end{array}$ & $\begin{array}{c}-0.030 \\
{[0.002]}\end{array}$ & $\begin{array}{c}0.124 \\
(0.009)\end{array}$ & $\begin{array}{c}0.085 \\
(0.007)\end{array}$ & $\begin{array}{c}-0.039 \\
{[0.001]}\end{array}$ & $\begin{array}{c}0.125 \\
(0.012)\end{array}$ & $\begin{array}{c}0.089 \\
(0.008)\end{array}$ & $\begin{array}{c}-0.035 \\
{[0.018]}\end{array}$ \\
\hline Observations & 2,642 & 1,747 & - & 1,564 & 1,747 & - & 808 & 1,297 & - \\
\hline
\end{tabular}


Table A4: Descriptive Statistics: Non-bordering Countries

\begin{tabular}{|c|c|c|c|c|c|c|c|c|c|}
\hline & $(1)$ & $(2)$ & (3) & (4) & $(5)$ & (6) & (7) & $(8)$ & (9) \\
\hline Sampling Window & \multicolumn{3}{|c|}{ Full Sample } & \multicolumn{3}{|c|}{ [-47 days, 47 days $]$} & \multicolumn{3}{|c|}{ [-30 days, 30 days $]$} \\
\hline Sampling Period & Pre & Post & Difference & Pre & Post & Difference & Pre & Post & Difference \\
\hline \multicolumn{10}{|l|}{ Outcome Variables } \\
\hline Social Capital & $\begin{array}{c}0.011 \\
(0.016)\end{array}$ & $\begin{array}{c}0.006 \\
(0.023)\end{array}$ & $\begin{array}{c}-0.005 \\
{[0.853]}\end{array}$ & $\begin{array}{c}0.004 \\
(0.022)\end{array}$ & $\begin{array}{c}0.006 \\
(0.023)\end{array}$ & $\begin{array}{c}0.003 \\
{[0.936]}\end{array}$ & $\begin{array}{c}0.055 \\
(0.032)\end{array}$ & $\begin{array}{c}0.025 \\
(0.025)\end{array}$ & $\begin{array}{l}-0.031 \\
{[0.449]}\end{array}$ \\
\hline Institutional Trust & $\begin{array}{c}0.023 \\
(0.016)\end{array}$ & $\begin{array}{c}0.001 \\
(0.023)\end{array}$ & $\begin{array}{l}-0.022 \\
{[0.447]}\end{array}$ & $\begin{array}{c}0.011 \\
(0.022)\end{array}$ & $\begin{array}{c}0.001 \\
(0.023)\end{array}$ & $\begin{array}{c}-0.010 \\
{[0.754]}\end{array}$ & $\begin{array}{c}0.031 \\
(0.032)\end{array}$ & $\begin{array}{c}0.011 \\
(0.025)\end{array}$ & $\begin{array}{l}-0.020 \\
{[0.621]}\end{array}$ \\
\hline Interpersonal Trust & $\begin{array}{c}0.027 \\
(0.016)\end{array}$ & $\begin{array}{l}-0.034 \\
(0.025)\end{array}$ & $\begin{array}{l}-0.061 \\
{[0.038]}\end{array}$ & $\begin{array}{c}0.008 \\
(0.022)\end{array}$ & $\begin{array}{l}-0.034 \\
(0.025)\end{array}$ & $\begin{array}{l}-0.043 \\
{[0.195]}\end{array}$ & $\begin{array}{c}0.015 \\
(0.031)\end{array}$ & $\begin{array}{l}-0.032 \\
(0.027)\end{array}$ & $\begin{array}{l}-0.046 \\
{[0.263]}\end{array}$ \\
\hline Social Networks & $\begin{array}{l}-0.009 \\
(0.016)\end{array}$ & $\begin{array}{c}0.051 \\
(0.024)\end{array}$ & $\begin{array}{c}0.060 \\
{[0.036]}\end{array}$ & $\begin{array}{c}0.003 \\
(0.022)\end{array}$ & $\begin{array}{c}0.051 \\
(0.024)\end{array}$ & $\begin{array}{c}0.048 \\
{[0.134]}\end{array}$ & $\begin{array}{c}0.035 \\
(0.032)\end{array}$ & $\begin{array}{c}0.060 \\
(0.025)\end{array}$ & $\begin{array}{c}0.025 \\
{[0.530]}\end{array}$ \\
\hline Reciprocity & $\begin{array}{l}-0.014 \\
(0.016)\end{array}$ & $\begin{array}{c}0.020 \\
(0.024)\end{array}$ & $\begin{array}{c}0.034 \\
{[0.250]}\end{array}$ & $\begin{array}{l}-0.015 \\
(0.022)\end{array}$ & $\begin{array}{c}0.020 \\
(0.024)\end{array}$ & $\begin{array}{c}0.035 \\
{[0.291]}\end{array}$ & $\begin{array}{c}0.058 \\
(0.032)\end{array}$ & $\begin{array}{c}0.040 \\
(0.026)\end{array}$ & $\begin{array}{c}-0.018 \\
{[0.662]}\end{array}$ \\
\hline Tolerance & $\begin{array}{l}-0.000 \\
(0.016)\end{array}$ & $\begin{array}{l}-0.024 \\
(0.025)\end{array}$ & $\begin{array}{c}-0.023 \\
{[0.422]}\end{array}$ & $\begin{array}{c}0.000 \\
(0.021)\end{array}$ & $\begin{array}{l}-0.024 \\
(0.025)\end{array}$ & $\begin{array}{c}-0.024 \\
{[0.461]}\end{array}$ & $\begin{array}{c}0.012 \\
(0.031)\end{array}$ & $\begin{array}{l}-0.012 \\
(0.027)\end{array}$ & $\begin{array}{c}-0.024 \\
{[0.560]}\end{array}$ \\
\hline \multicolumn{10}{|l|}{ Covariates } \\
\hline Age & $\begin{array}{l}47.601 \\
(0.275)\end{array}$ & $\begin{array}{l}47.234 \\
(0.393)\end{array}$ & $\begin{array}{c}-0.367 \\
{[0.444]}\end{array}$ & $\begin{array}{l}46.697 \\
(0.374)\end{array}$ & $\begin{array}{l}47.234 \\
(0.393)\end{array}$ & $\begin{array}{c}0.538 \\
{[0.322]}\end{array}$ & $\begin{array}{l}46.166 \\
(0.541)\end{array}$ & $\begin{array}{l}46.991 \\
(0.414)\end{array}$ & $\begin{array}{c}0.825 \\
{[0.226]}\end{array}$ \\
\hline I(Male) & $\begin{array}{c}0.499 \\
(0.008)\end{array}$ & $\begin{array}{c}0.464 \\
(0.012)\end{array}$ & $\begin{array}{l}-0.035 \\
{[0.014]}\end{array}$ & $\begin{array}{c}0.494 \\
(0.011)\end{array}$ & $\begin{array}{c}0.464 \\
(0.012)\end{array}$ & $\begin{array}{l}-0.030 \\
{[0.062]}\end{array}$ & $\begin{array}{c}0.474 \\
(0.016)\end{array}$ & $\begin{array}{c}0.463 \\
(0.013)\end{array}$ & $\begin{array}{l}-0.011 \\
{[0.577]}\end{array}$ \\
\hline Education & $\begin{array}{l}13.497 \\
(0.061)\end{array}$ & $\begin{array}{l}13.240 \\
(0.072)\end{array}$ & $\begin{array}{l}-0.257 \\
{[0.006]}\end{array}$ & $\begin{array}{c}13.543 \\
(0.078)\end{array}$ & $\begin{array}{l}13.240 \\
(0.072)\end{array}$ & $\begin{array}{c}-0.303 \\
{[0.004]}\end{array}$ & $\begin{array}{c}13.672 \\
(0.110)\end{array}$ & $\begin{array}{r}13.365 \\
(0.075)\end{array}$ & $\begin{array}{c}-0.308 \\
{[0.021]}\end{array}$ \\
\hline \multicolumn{10}{|l|}{ HH Total Income } \\
\hline $\mathrm{I}\left(1^{\text {st }}\right.$ decile $)$ & $\begin{array}{c}0.093 \\
(0.005)\end{array}$ & $\begin{array}{c}0.083 \\
(0.006)\end{array}$ & $\begin{array}{c}-0.011 \\
{[0.144]}\end{array}$ & $\begin{array}{c}0.092 \\
(0.006)\end{array}$ & $\begin{array}{c}0.083 \\
(0.006)\end{array}$ & $\begin{array}{c}-0.009 \\
{[0.261]}\end{array}$ & $\begin{array}{c}0.088 \\
(0.008)\end{array}$ & $\begin{array}{c}0.079 \\
(0.006)\end{array}$ & $\begin{array}{c}-0.009 \\
{[0.356]}\end{array}$ \\
\hline $\mathrm{I}\left(2^{\text {nd }}\right.$ decile $)$ & $\begin{array}{c}0.095 \\
(0.005)\end{array}$ & $\begin{array}{c}0.099 \\
(0.007)\end{array}$ & $\begin{array}{c}0.004 \\
{[0.630]}\end{array}$ & $\begin{array}{c}0.094 \\
(0.006)\end{array}$ & $\begin{array}{c}0.099 \\
(0.007)\end{array}$ & $\begin{array}{c}0.005 \\
{[0.597]}\end{array}$ & $\begin{array}{c}0.092 \\
(0.009)\end{array}$ & $\begin{array}{c}0.094 \\
(0.007)\end{array}$ & $\begin{array}{c}0.003 \\
{[0.811]}\end{array}$ \\
\hline $\mathrm{I}\left(3^{\text {rd }}\right.$ decile $)$ & $\begin{array}{c}0.093 \\
(0.005)\end{array}$ & $\begin{array}{c}0.105 \\
(0.007)\end{array}$ & $\begin{array}{c}0.012 \\
{[0.151]}\end{array}$ & $\begin{array}{c}0.089 \\
(0.006)\end{array}$ & $\begin{array}{c}0.105 \\
(0.007)\end{array}$ & $\begin{array}{c}0.016 \\
{[0.084]}\end{array}$ & $\begin{array}{c}0.078 \\
(0.008)\end{array}$ & $\begin{array}{c}0.103 \\
(0.007)\end{array}$ & $\begin{array}{c}0.025 \\
{[0.021]}\end{array}$ \\
\hline $\mathrm{I}\left(4^{\text {th }}\right.$ decile $)$ & $\begin{array}{c}0.109 \\
(0.005)\end{array}$ & $\begin{array}{c}0.121 \\
(0.008)\end{array}$ & $\begin{array}{c}0.012 \\
{[0.189]}\end{array}$ & $\begin{array}{c}0.107 \\
(0.007)\end{array}$ & $\begin{array}{c}0.121 \\
(0.008)\end{array}$ & $\begin{array}{c}0.013 \\
{[0.182]}\end{array}$ & $\begin{array}{c}0.111 \\
(0.010)\end{array}$ & $\begin{array}{c}0.118 \\
(0.008)\end{array}$ & $\begin{array}{c}0.007 \\
{[0.591]}\end{array}$ \\
\hline $\mathrm{I}\left(5^{\text {th }}\right.$ decile $)$ & $\begin{array}{c}0.111 \\
(0.005)\end{array}$ & $\begin{array}{c}0.131 \\
(0.008)\end{array}$ & $\begin{array}{c}0.019 \\
{[0.038]}\end{array}$ & $\begin{array}{c}0.126 \\
(0.007)\end{array}$ & $\begin{array}{c}0.131 \\
(0.008)\end{array}$ & $\begin{array}{c}0.005 \\
{[0.633]}\end{array}$ & $\begin{array}{c}0.127 \\
(0.010)\end{array}$ & $\begin{array}{c}0.131 \\
(0.008)\end{array}$ & $\begin{array}{c}0.005 \\
{[0.732]}\end{array}$ \\
\hline $\mathrm{I}\left(6^{\text {th }}\right.$ decile $)$ & $\begin{array}{c}0.113 \\
(0.005)\end{array}$ & $\begin{array}{c}0.125 \\
(0.008)\end{array}$ & $\begin{array}{c}0.013 \\
{[0.176]}\end{array}$ & $\begin{array}{c}0.119 \\
(0.007)\end{array}$ & $\begin{array}{c}0.125 \\
(0.008)\end{array}$ & $\begin{array}{c}0.007 \\
{[0.513]}\end{array}$ & $\begin{array}{c}0.126 \\
(0.011)\end{array}$ & $\begin{array}{c}0.129 \\
(0.008)\end{array}$ & $\begin{array}{c}0.004 \\
{[0.797]}\end{array}$ \\
\hline $\mathrm{I}\left(7^{\text {th }}\right.$ decile $)$ & $\begin{array}{c}0.111 \\
(0.005)\end{array}$ & $\begin{array}{c}0.112 \\
(0.008)\end{array}$ & $\begin{array}{c}0.001 \\
{[0.953]}\end{array}$ & $\begin{array}{c}0.117 \\
(0.007)\end{array}$ & $\begin{array}{c}0.112 \\
(0.008)\end{array}$ & $\begin{array}{c}-0.005 \\
{[0.648]}\end{array}$ & $\begin{array}{c}0.116 \\
(0.011)\end{array}$ & $\begin{array}{c}0.112 \\
(0.008)\end{array}$ & $\begin{array}{c}-0.004 \\
{[0.755]}\end{array}$ \\
\hline $\mathrm{I}\left(8^{\text {th }}\right.$ decile $)$ & $\begin{array}{c}0.102 \\
(0.005)\end{array}$ & $\begin{array}{c}0.110 \\
(0.008)\end{array}$ & $\begin{array}{c}0.008 \\
{[0.364]}\end{array}$ & $\begin{array}{c}0.106 \\
(0.007)\end{array}$ & $\begin{array}{c}0.110 \\
(0.008)\end{array}$ & $\begin{array}{c}0.004 \\
{[0.688]}\end{array}$ & $\begin{array}{c}0.108 \\
(0.010)\end{array}$ & $\begin{array}{c}0.114 \\
(0.008)\end{array}$ & $\begin{array}{c}0.006 \\
{[0.624]}\end{array}$ \\
\hline $\mathrm{I}\left(9^{\text {th }}\right.$ decile $)$ & $\begin{array}{c}0.081 \\
(0.004)\end{array}$ & $\begin{array}{c}0.058 \\
(0.006)\end{array}$ & $\begin{array}{c}-0.023 \\
{[0.001]}\end{array}$ & $\begin{array}{c}0.075 \\
(0.006)\end{array}$ & $\begin{array}{c}0.058 \\
(0.006)\end{array}$ & $\begin{array}{c}-0.017 \\
{[0.037]}\end{array}$ & $\begin{array}{c}0.078 \\
(0.009)\end{array}$ & $\begin{array}{c}0.060 \\
(0.006)\end{array}$ & $\begin{array}{c}-0.018 \\
{[0.101]}\end{array}$ \\
\hline $\mathrm{I}\left(10^{\text {th }}\right.$ decile $)$ & $\begin{array}{c}0.091 \\
(0.005)\end{array}$ & $\begin{array}{c}0.057 \\
(0.006)\end{array}$ & $\begin{array}{c}-0.034 \\
{[0.000]}\end{array}$ & $\begin{array}{c}0.076 \\
(0.006)\end{array}$ & $\begin{array}{c}0.057 \\
(0.006)\end{array}$ & $\begin{array}{c}-0.019 \\
{[0.024]}\end{array}$ & $\begin{array}{c}0.077 \\
(0.009)\end{array}$ & $\begin{array}{c}0.060 \\
(0.007)\end{array}$ & $\begin{array}{c}-0.017 \\
{[0.110]}\end{array}$ \\
\hline Observations & 4,187 & 2,125 & - & 2,320 & 2,125 & - & 1,141 & 1,858 & - \\
\hline
\end{tabular}

Notes: For each sample definition, this table reports sample means with sample standard deviations in parenthesis as well as differences of sample means along with p-values corresponding to tests for the equality of means in brackets. 
Table A5: DID Estimates (Social Capital Index)

\begin{tabular}{|c|c|c|c|c|c|}
\hline (A) [Full Sample] & $(1)$ & $(2)$ & (3) & (4) & $(5)$ \\
\hline Treat $x$ Post & $\begin{array}{c}0.359 * * * \\
(0.0748)\end{array}$ & $\begin{array}{c}0.276 * * * \\
(0.0726)\end{array}$ & $\begin{array}{c}0.271 * * * \\
(0.0727)\end{array}$ & $\begin{array}{c}0.243 * * * \\
(0.0832)\end{array}$ & $\begin{array}{c}0.261 * * * \\
(0.0755)\end{array}$ \\
\hline Observations & 12,466 & 12,466 & 12,466 & 6,154 & 8,077 \\
\hline (B) [-47 days, 47 days] & $(1)$ & $(2)$ & (3) & (4) & $(5)$ \\
\hline Treat $x$ Post & $\begin{array}{c}0.371 * * * \\
(0.0777)\end{array}$ & $\begin{array}{c}0.292 * * * \\
(0.0756)\end{array}$ & $\begin{array}{c}0.288^{* * * *} \\
(0.0758)\end{array}$ & $\begin{array}{c}0.292 * * * \\
(0.0869)\end{array}$ & $\begin{array}{c}0.263^{* * *} * \\
(0.0790)\end{array}$ \\
\hline Observations & 9,260 & 9,260 & 9,260 & 4,815 & 5,949 \\
\hline (C) [-30 days, 30 days $]$ & $(1)$ & $(2)$ & (3) & (4) & $(5)$ \\
\hline Treat $x$ Post & $\begin{array}{c}0.328 * * * \\
(0.100)\end{array}$ & $\begin{array}{c}0.270^{* * *} \\
(0.0979)\end{array}$ & $\begin{array}{c}0.272 * * * \\
(0.0979)\end{array}$ & $\begin{array}{c}0.236^{* *} \\
(0.110)\end{array}$ & $\begin{array}{c}0.270^{* * *} \\
(0.101)\end{array}$ \\
\hline Observations & 5,751 & 5,751 & 5,751 & 2,752 & 3,646 \\
\hline Country FE & $y$ & $y$ & $y$ & $y$ & $y$ \\
\hline Demographic Controls & $n$ & $y$ & $y$ & $y$ & $y$ \\
\hline Week FE & $n$ & $n$ & $y$ & $y$ & $y$ \\
\hline Includes Bordering Countries & $y$ & $y$ & $y$ & $y$ & $n$ \\
\hline Includes Non-Bordering Countries & $y$ & $y$ & $y$ & $n$ & $y$ \\
\hline
\end{tabular}


Table A6: DID Estimates (Trust in Institutions Index)

\begin{tabular}{lccccc}
\hline (A) [Full Sample] & $(1)$ & $(2)$ & $(3)$ & $(4)$ & $(5)$ \\
\hline Treat x Post & $0.372^{* * *}$ & $0.304^{* * *}$ & $0.311^{* * *}$ & $0.265^{* * *}$ & $0.318^{* * *}$ \\
& $(0.0790)$ & $(0.0784)$ & $(0.0790)$ & $(0.0883)$ & $(0.0819)$ \\
Observations & 12,466 & 12,466 & 12,466 & 6,154 & 8,077 \\
\hline (B) [-47 days, 47 days] & $(1)$ & $(2)$ & $(3)$ & $(4)$ & $(5)$ \\
\hline Treat x Post & $0.384^{* * *}$ & $0.325^{* * *}$ & $0.338^{* * *}$ & $0.309^{* * *}$ & $0.337 * * *$ \\
& $(0.0813)$ & $(0.0805)$ & $(0.0809)$ & $(0.0905)$ & $(0.0846)$ \\
Observations & 9,260 & 9,260 & 9,260 & 4,815 & 5,949 \\
\hline C) [-30 days, 30 days] & $(1)$ & $(2)$ & $(3)$ & $(4)$ & $(5)$ \\
\hline \multirow{2}{*}{ Treat x Post } & $0.326^{* * *}$ & $0.274^{* * *}$ & $0.294 * * *$ & $0.227 * *$ & $0.318^{* * *}$ \\
& $(0.103)$ & $(0.101)$ & $(0.101)$ & $(0.111)$ & $(0.106)$ \\
Observations & 5,751 & 5,751 & 5,751 & 2,752 & 3,646 \\
\hline Country FE & $y$ & $y$ & $y$ & $y$ & $y$ \\
Demographic Controls & $n$ & $y$ & $y$ & $y$ & $y$ \\
Week FE & $n$ & $n$ & $y$ & $y$ & $y$ \\
Includes Bordering Countries & $y$ & $y$ & $y$ & $y$ & $n$ \\
Includes Non-Bordering Countries & $y$ & $y$ & $y$ & $n$ & $y$ \\
\hline
\end{tabular}

Notes: $* * * \mathrm{p}<0.01, * * \mathrm{p}<0.05,{ }^{*} \mathrm{p}<0.1$. Robust (Huber-White) standard errors in parentheses. Columns (1) (5) report coefficient estimates of the treatment group by post Charlie Hebdo interaction terms as specified in estimating equation (1) with the Trust in Institutions index as the dependent variable. The set of demographic controls include: Second-order polynomials in age and education (in years); a binary variable indicating if the respondent is female; and a set of categorical variables indicating the decile of the respondent's household's total net income. 
Table A7: DID Estimates (Interpersonal Trust Index)

\begin{tabular}{|c|c|c|c|c|c|}
\hline (A) [Full Sample] & $(1)$ & (2) & (3) & (4) & (5) \\
\hline Treat $\mathrm{x}$ Post & $\begin{array}{c}0.244 * * * \\
(0.0731)\end{array}$ & $\begin{array}{l}0.173^{* *} \\
(0.0724)\end{array}$ & $\begin{array}{l}0.183 * * \\
(0.0733)\end{array}$ & $\begin{array}{c}0.153 * \\
(0.0832)\end{array}$ & $\begin{array}{l}0.188 * * \\
(0.0764)\end{array}$ \\
\hline Observations & 12,466 & 12,466 & 12,466 & 6,154 & 8,077 \\
\hline (B) [-47 days, 47 days $]$ & $(1)$ & (2) & (3) & (4) & (5) \\
\hline Treat $x$ Post & $\begin{array}{c}0.273 * * * \\
(0.0753)\end{array}$ & $\begin{array}{c}0.212 * * * \\
(0.0744)\end{array}$ & $\begin{array}{c}0.222 * * * \\
(0.0752)\end{array}$ & $\begin{array}{l}0.220^{* *} \\
(0.0857)\end{array}$ & $\begin{array}{r}0.213 * * * \\
(0.0790)\end{array}$ \\
\hline Observations & 9,260 & 9,260 & 9,260 & 4,815 & 5,949 \\
\hline (C) [-30 days, 30 days $]$ & $(1)$ & $(2)$ & (3) & (4) & $(5)$ \\
\hline Treat $x$ Post & $\begin{array}{c}0.275 * * * \\
(0.0965)\end{array}$ & $\begin{array}{l}0.225^{* *} \\
(0.0947)\end{array}$ & $\begin{array}{l}0.229 * * \\
(0.0955)\end{array}$ & $\begin{array}{l}0.210^{*} \\
(0.107)\end{array}$ & $\begin{array}{l}0.228^{* *} \\
(0.0995)\end{array}$ \\
\hline Observations & 5,751 & 5,751 & 5,751 & 2,752 & 3,646 \\
\hline Country FE & $y$ & $y$ & $y$ & $y$ & $y$ \\
\hline Demographic Controls & $n$ & $y$ & $y$ & $y$ & $y$ \\
\hline Week FE & $n$ & $n$ & $y$ & $y$ & $y$ \\
\hline Includes Bordering Countries & $y$ & $y$ & $y$ & $y$ & $n$ \\
\hline Includes Non-Bordering Countries & $y$ & $y$ & $y$ & $n$ & $y$ \\
\hline $\begin{array}{l}\text { Notes: }{ }^{* * *} \mathrm{p}<0.01,{ }^{* *} \mathrm{p}<0.05,{ }^{*} \mathrm{p}<0.1 . \mathrm{R} \\
\text { report coefficient estimates of the treatm } \\
\text { estimating equation (1) with the Interpers } \\
\text { controls include: Second-order polynomi } \\
\text { respondent is female; and a set of categc } \\
\text { total net income. }\end{array}$ & $\begin{array}{l}\mathrm{t}(\text { Huber-W } \\
\text { group by } \\
l \text { Trust inde } \\
\text { age and } \mathrm{e} \\
\text { l variables } \mathrm{i}\end{array}$ & $\begin{array}{l}\text { ite) standa } \\
\text { st Charlie } \\
\text { as the de } \\
\text { ication (in } \\
\text { dicating } t\end{array}$ & $\begin{array}{l}\text { rrors in } p \\
\text { bdo inter } \\
\text { lent varia } \\
\text { ars); a bin } \\
\text { ecile of } t\end{array}$ & $\begin{array}{l}\text { heses. } \\
\text { n terms } \\
\text { The set } \\
\text { ariable }\end{array}$ & $\begin{array}{l}\text { umns (1) - (5) } \\
\text { specified in } \\
\text { demographic } \\
\text { icating if the } \\
\text { household's }\end{array}$ \\
\hline
\end{tabular}


Table A8: DID Estimates (Engagement in (Informal) Social Networks Index)

\begin{tabular}{|c|c|c|c|c|c|}
\hline (A) [Full Sample] & (1) & (2) & (3) & (4) & (5) \\
\hline Treat $x$ Post & $\begin{array}{l}0.211^{* *} \\
(0.0872)\end{array}$ & $\begin{array}{c}0.143 * \\
(0.0852)\end{array}$ & $\begin{array}{c}0.138 \\
(0.0857)\end{array}$ & $\begin{array}{c}0.147 \\
(0.0938)\end{array}$ & $\begin{array}{c}0.122 \\
(0.0880)\end{array}$ \\
\hline Observations & 12,466 & 12,466 & 12,466 & 6,154 & 8,077 \\
\hline (B) [-47 days, 47 days] & (1) & (2) & (3) & (4) & (5) \\
\hline Treat $x$ Post & $\begin{array}{l}0.189 * * \\
(0.0892)\end{array}$ & $\begin{array}{c}0.116 \\
(0.0874)\end{array}$ & $\begin{array}{c}0.109 \\
(0.0878)\end{array}$ & $\begin{array}{c}0.130 \\
(0.0965)\end{array}$ & $\begin{array}{c}0.0931 \\
(0.0905)\end{array}$ \\
\hline Observations & 9,260 & 9,260 & 9,260 & 4,815 & 5,949 \\
\hline (C) [-30 days, 30 days] & $(1)$ & $(2)$ & (3) & (4) & $(5)$ \\
\hline Treat $x$ Post & $\begin{array}{c}0.170 \\
(0.107)\end{array}$ & $\begin{array}{c}0.117 \\
(0.105)\end{array}$ & $\begin{array}{c}0.120 \\
(0.105)\end{array}$ & $\begin{array}{c}0.178 \\
(0.117)\end{array}$ & $\begin{array}{l}0.0812 \\
(0.108)\end{array}$ \\
\hline Observations & 5,751 & 5,751 & 5,751 & 2,752 & 3,646 \\
\hline Country FE & $y$ & $y$ & $y$ & $y$ & $y$ \\
\hline Demographic Controls & $n$ & $y$ & $y$ & $y$ & $y$ \\
\hline Week FE & $n$ & $n$ & $y$ & $y$ & $y$ \\
\hline Includes Bordering Countries & $y$ & $y$ & $y$ & $y$ & $n$ \\
\hline Includes Non-Bordering Countries & $y$ & $y$ & $y$ & $n$ & $y$ \\
\hline $\begin{array}{l}\text { Notes: }{ }^{* * *} \mathrm{p}<0.01, * * \mathrm{p}<0.05, * \mathrm{p}<0.1 . \mathrm{Rc} \\
\text { report coefficient estimates of the treatm } \\
\text { estimating equation (1) with the Engager } \\
\text { The set of demographic controls include: } \\
\text { variable indicating if the respondent is } \\
\text { respondent's household's total net income }\end{array}$ & $\begin{array}{l}\text { t(Huber } \\
\text { group b } \\
\text { in (Info } \\
\text { ond-orde } \\
\text { le; and a }\end{array}$ & nomial & $\begin{array}{l}\text { Tors in } \\
\text { do inte } \\
\text { rks ind } \\
\text { ge and }\end{array}$ & $\begin{array}{l}\text { heses. } \\
\text { n terms } \\
\text { the depe } \\
\text { tion (in }\end{array}$ & $\begin{array}{l}\text { mns (1) - (5) } \\
\text { specified in } \\
\text { ent variable. } \\
\text { rs); a binary } \\
\text { decile of the }\end{array}$ \\
\hline
\end{tabular}


Table A9: DID Estimates (Values/Norms of Reciprocity Index)

\begin{tabular}{lccccc}
\hline (A) [Full Sample] & $(1)$ & $(2)$ & $(3)$ & $(4)$ & $(5)$ \\
\hline Treat x Post & 0.0825 & 0.0762 & 0.0595 & 0.0803 & 0.0238 \\
& $(0.0823)$ & $(0.0809)$ & $(0.0815)$ & $(0.0900)$ & $(0.0846)$ \\
Observations & 12,466 & 12,466 & 12,466 & 6,154 & 8,077 \\
\hline (B) [-47 days, 47 days] & $(1)$ & $(2)$ & $(3)$ & $(4)$ & $(5)$ \\
\hline Treat x Post & 0.0860 & 0.0801 & 0.0637 & 0.0854 & 0.0260 \\
& $(0.0850)$ & $(0.0836)$ & $(0.0841)$ & $(0.0936)$ & $(0.0878)$ \\
Observations & 9,260 & 9,260 & 9,260 & 4,815 & 5,949 \\
\hline C) [-30 days, 30 days] & $(1)$ & $(2)$ & $(3)$ & $(4)$ & $(5)$ \\
\hline Treat x Post & 0.0206 & 0.0356 & 0.0227 & -0.0276 & 0.0214 \\
& $(0.106)$ & $(0.105)$ & $(0.106)$ & $(0.116)$ & $(0.111)$ \\
Observations & 5,751 & 5,751 & 5,751 & 2,752 & 3,646 \\
\hline Country FE & $y$ & $y$ & $y$ & $y$ & $y$ \\
Demographic Controls & $n$ & $y$ & $y$ & $y$ & $y$ \\
Week FE & $n$ & $n$ & $y$ & $y$ & $y$ \\
Includes Bordering Countries & $y$ & $y$ & $y$ & $y$ & $n$ \\
Includes Non-Bordering Countries & $y$ & $y$ & $y$ & $n$ & $y$ \\
\hline
\end{tabular}

Notes: $* * * \mathrm{p}<0.01, * * \mathrm{p}<0.05, * \mathrm{p}<0.1$. Robust (Huber-White) standard errors in parentheses. Columns (1) (5) report coefficient estimates of the treatment group by post Charlie Hebdo interaction terms as specified in estimating equation (1) with the Values/Norms of Reciprocity index as the dependent variable. The set of demographic controls include: Second-order polynomials in age and education (in years); a binary variable indicating if the respondent is female; and a set of categorical variables indicating the decile of the respondent's household's total net income. 
Table A10: DID Estimates (Ethnic Tolerance/Tolerance of Diversity Index)

\begin{tabular}{lccccc}
\hline (A) [Full Sample] & $(1)$ & $(2)$ & $(3)$ & $(4)$ & $(5)$ \\
\hline Treat x Post & 0.0302 & 0.0267 & 0.0145 & -0.0196 & 0.0303 \\
& $(0.0769)$ & $(0.0760)$ & $(0.0776)$ & $(0.0860)$ & $(0.0817)$ \\
Observations & 12,466 & 12,466 & 12,466 & 6,154 & 8,077 \\
\hline (B) [-47 days, 47 days] & $(1)$ & $(2)$ & $(3)$ & $(4)$ & $(5)$ \\
\hline Treat x Post & 0.0386 & 0.0279 & 0.00953 & 0.0134 & 0.00707 \\
& $(0.0795)$ & $(0.0788)$ & $(0.0801)$ & $(0.0893)$ & $(0.0848)$ \\
Observations & 9,260 & 9,260 & 9,260 & 4,815 & 5,949 \\
\hline C) [-30 days, 30 days] & $(1)$ & $(2)$ & $(3)$ & $(4)$ & $(5)$ \\
\hline Treat x Post & 0.0719 & 0.0580 & 0.0460 & 0.0273 & 0.0573 \\
& $(0.0959)$ & $(0.0951)$ & $(0.0959)$ & $(0.104)$ & $(0.102)$ \\
Observations & 5,751 & 5,751 & 5,751 & 2,752 & 3,646 \\
\hline Country FE & $y$ & $y$ & $y$ & $y$ & $y$ \\
Demographic Controls & $n$ & $y$ & $y$ & $y$ & $y$ \\
Week FE & $n$ & $n$ & $y$ & $y$ & $y$ \\
Includes Bordering Countries & $y$ & $y$ & $y$ & $y$ & $n$ \\
Includes Non-Bordering Countries & $y$ & $y$ & $y$ & $n$ & $y$ \\
\hline
\end{tabular}

Notes: $* * * \mathrm{p}<0.01, * * \mathrm{p}<0.05, * \mathrm{p}<0.1$. Robust (Huber-White) standard errors in parentheses. Columns (1) (5) report coefficient estimates of the treatment group by post Charlie Hebdo interaction terms as specified in estimating equation (1) with the Ethnic Tolerance/Tolerance of Diversity index as the dependent variable. The set of demographic controls include: Second-order polynomials in age and education (in years); a binary variable indicating if the respondent is female; and a set of categorical variables indicating the decile of the respondent's household's total net income. 
Table A11: Trend Analysis - (Social Capital Index)

\begin{tabular}{|c|c|c|c|c|c|}
\hline (A) [-68 days, 0 days $]$ & (1) & (2) & (3) & (4) & (5) \\
\hline Days Since Event & $\begin{array}{c}0.000704 \\
(0.000849)\end{array}$ & $\begin{array}{c}0.000398 \\
(0.000820)\end{array}$ & $\begin{array}{l}-0.00560 \\
(0.00508)\end{array}$ & $\begin{array}{l}-0.00756 \\
(0.00729)\end{array}$ & $\begin{array}{l}-0.00735 \\
(0.00637)\end{array}$ \\
\hline Treat x Days Since Event & $\begin{array}{l}-0.000332 \\
(0.00322)\end{array}$ & $\begin{array}{l}-0.00119 \\
(0.00308)\end{array}$ & $\begin{array}{l}-0.00175 \\
(0.00316)\end{array}$ & $\begin{array}{l}-0.00240 \\
(0.00338)\end{array}$ & $\begin{array}{l}-0.00226 \\
(0.00331)\end{array}$ \\
\hline Observations & 8,322 & 8,322 & 8,322 & 4,135 & 5,680 \\
\hline (B) [-47 days, 0 days $]$ & (1) & (2) & (3) & (4) & (5) \\
\hline Days Since Event & $\begin{array}{c}0.00130 \\
(0.00156)\end{array}$ & $\begin{array}{l}0.000851 \\
(0.00150)\end{array}$ & $\begin{array}{l}-0.00754 \\
(0.00721)\end{array}$ & $\begin{array}{c}-0.0105 \\
(0.00997)\end{array}$ & $\begin{array}{l}-0.00929 \\
(0.00898)\end{array}$ \\
\hline Treat x Days Since Event & $\begin{array}{c}0.00198 \\
(0.00435)\end{array}$ & $\begin{array}{c}0.00167 \\
(0.00420)\end{array}$ & $\begin{array}{c}0.00116 \\
(0.00422)\end{array}$ & $\begin{array}{c}0.00360 \\
(0.00455)\end{array}$ & $\begin{array}{l}-0.00145 \\
(0.00445)\end{array}$ \\
\hline Observations & 5,116 & 5,116 & 5,116 & 2,796 & 3,552 \\
\hline (C) [-30 days, 0 days $]$ & $(1)$ & (2) & (3) & (4) & (5) \\
\hline Days Since Event & $\begin{array}{l}0.000386 \\
(0.00313)\end{array}$ & $\begin{array}{c}-5.16 \mathrm{e}-05 \\
(0.00303)\end{array}$ & $\begin{array}{c}-0.00365 \\
(0.0117)\end{array}$ & $\begin{array}{c}-0.00140 \\
(0.0166)\end{array}$ & $\begin{array}{l}-0.0139 \\
(0.0150)\end{array}$ \\
\hline Treat x Days Since Event & $\begin{array}{c}-0.00628 \\
(0.0102)\end{array}$ & $\begin{array}{l}0.000334 \\
(0.00987)\end{array}$ & $\begin{array}{r}-0.000771 \\
(0.00989)\end{array}$ & $\begin{array}{l}0.00427 \\
(0.0105)\end{array}$ & $\begin{array}{r}-0.00455 \\
(0.0103)\end{array}$ \\
\hline Observations & 2,355 & 2,355 & 2,355 & 1,214 & 1,547 \\
\hline Country FE & $y$ & $y$ & $y$ & $\bar{y}$ & $y$ \\
\hline Demographic Controls & $n$ & $y$ & $y$ & $y$ & $y$ \\
\hline Week FE & $n$ & $n$ & $y$ & $y$ & $y$ \\
\hline Includes Bordering Countries & $y$ & $y$ & $y$ & $y$ & $n$ \\
\hline Includes Non-Bordering Countries & $y$ & $y$ & $y$ & $n$ & $y$ \\
\hline
\end{tabular}


Table A12: Trend Analysis - (Trust in Institutions Index)

\begin{tabular}{|c|c|c|c|c|c|}
\hline (A) [-68 days, 0 days $]$ & $(1)$ & (2) & (3) & (4) & $(5)$ \\
\hline Days Since Event & $\begin{array}{l}-0.00104 \\
(0.000846)\end{array}$ & $\begin{array}{l}-0.00127 \\
(0.000827)\end{array}$ & $\begin{array}{l}-0.00344 \\
(0.00500)\end{array}$ & $\begin{array}{l}-0.0116^{*} \\
(0.00699)\end{array}$ & $\begin{array}{l}-0.00239 \\
(0.00627)\end{array}$ \\
\hline Treat x Days Since Event & $\begin{array}{c}0.00268 \\
(0.00306)\end{array}$ & $\begin{array}{c}0.00240 \\
(0.00299)\end{array}$ & $\begin{array}{c}0.00188 \\
(0.00314)\end{array}$ & $\begin{array}{l}0.000432 \\
(0.00336)\end{array}$ & $\begin{array}{c}0.00236 \\
(0.00332)\end{array}$ \\
\hline Observations & 8,322 & 8,322 & 8,322 & 4,135 & 5,680 \\
\hline (B) [-47 days, 0 days $]$ & $(1)$ & $(2)$ & (3) & (4) & $(5)$ \\
\hline Days Since Event & $\begin{array}{l}-0.00232 \\
(0.00159)\end{array}$ & $\begin{array}{c}-0.00269^{*} \\
(0.00156)\end{array}$ & $\begin{array}{l}0.000110 \\
(0.00700)\end{array}$ & $\begin{array}{l}-0.00811 \\
(0.00940)\end{array}$ & $\begin{array}{l}7.98 \mathrm{e}-05 \\
(0.00881)\end{array}$ \\
\hline Treat x Days Since Event & $\begin{array}{c}0.00922 * * \\
(0.00394)\end{array}$ & $\begin{array}{c}0.00965^{* *} \\
(0.00383)\end{array}$ & $\begin{array}{c}0.00874 * * \\
(0.00389)\end{array}$ & $\begin{array}{c}0.00985^{* * *} \\
(0.00424)\end{array}$ & $\begin{array}{l}0.00730^{*} \\
(0.00419)\end{array}$ \\
\hline Observations & 5,116 & 5,116 & 5,116 & 2,796 & 3,552 \\
\hline (C) [-30 days, 0 days] & $(1)$ & $(2)$ & (3) & (4) & (5) \\
\hline Days Since Event & $\begin{array}{c}-0.00550^{*} \\
(0.00312)\end{array}$ & $\begin{array}{c}-0.00620^{* *} \\
(0.00307)\end{array}$ & $\begin{array}{l}0.00957 \\
(0.0112)\end{array}$ & $\begin{array}{l}0.00426 \\
(0.0151)\end{array}$ & $\begin{array}{l}0.00860 \\
(0.0147)\end{array}$ \\
\hline Treat x Days Since Event & $\begin{array}{c}0.00712 \\
(0.00908)\end{array}$ & $\begin{array}{c}0.0125 \\
(0.00885)\end{array}$ & $\begin{array}{c}0.0120 \\
(0.00899)\end{array}$ & $\begin{array}{c}0.0123 \\
(0.00955)\end{array}$ & $\begin{array}{c}0.0119 \\
(0.00953)\end{array}$ \\
\hline Observations & 2,355 & 2,355 & 2,355 & 1,214 & 1,547 \\
\hline Country FE & $y$ & $y$ & $y$ & $y$ & $y$ \\
\hline Demographic Controls & $n$ & $y$ & $y$ & $y$ & $y$ \\
\hline Week FE & $n$ & $n$ & $y$ & $y$ & $y$ \\
\hline Includes Bordering Countries & $y$ & $y$ & $y$ & $y$ & $n$ \\
\hline Includes Non-Bordering Countries & $y$ & $y$ & $y$ & $n$ & $y$ \\
\hline
\end{tabular}


Table A13: Trend Analysis - (Interpersonal Trust Index)

\begin{tabular}{|c|c|c|c|c|c|}
\hline (A) [-68 days, 0 days] & $(1)$ & $(2)$ & (3) & (4) & (5) \\
\hline Days Since Event & $\begin{array}{c}7.95 \mathrm{e}-05 \\
(0.000837)\end{array}$ & $\begin{array}{c}0.000152 \\
(0.000816)\end{array}$ & $\begin{array}{c}-0.00927 * \\
(0.00500)\end{array}$ & $\begin{array}{l}-0.00904 \\
(0.00704)\end{array}$ & $\begin{array}{c}-0.0131 * * \\
(0.00627)\end{array}$ \\
\hline Treat $x$ Days Since Event & $\begin{array}{l}-0.00307 \\
(0.00320)\end{array}$ & $\begin{array}{l}-0.00382 \\
(0.00309)\end{array}$ & $\begin{array}{l}-0.00390 \\
(0.00319)\end{array}$ & $\begin{array}{l}-0.00465 \\
(0.00343)\end{array}$ & $\begin{array}{l}-0.00356 \\
(0.00337)\end{array}$ \\
\hline Observations & 8,322 & 8,322 & 8,322 & 4,135 & 5,680 \\
\hline (B) [-47 days, 0 days $]$ & $(1)$ & $(2)$ & (3) & (4) & $(5)$ \\
\hline Days Since Event & $\begin{array}{c}-0.000536 \\
(0.00153)\end{array}$ & $\begin{array}{c}-0.000882 \\
(0.00149)\end{array}$ & $\begin{array}{l}-0.00941 \\
(0.00706)\end{array}$ & $\begin{array}{c}-0.0133 \\
(0.00964)\end{array}$ & $\begin{array}{c}-0.0104 \\
(0.00868)\end{array}$ \\
\hline Treat x Days Since Event & $\begin{array}{l}-0.00145 \\
(0.00411)\end{array}$ & $\begin{array}{l}-0.00120 \\
(0.00400)\end{array}$ & $\begin{array}{l}-0.00116 \\
(0.00403)\end{array}$ & $\begin{array}{l}0.000385 \\
(0.00439)\end{array}$ & $\begin{array}{l}-0.00288 \\
(0.00429)\end{array}$ \\
\hline Observations & 5,116 & 5,116 & 5,116 & 2,796 & 3,552 \\
\hline (C) [-30 days, 0 days $]$ & $(1)$ & $(2)$ & (3) & (4) & (5) \\
\hline Days Since Event & $\begin{array}{c}0.00170 \\
(0.00297)\end{array}$ & $\begin{array}{l}0.000957 \\
(0.00293)\end{array}$ & $\begin{array}{c}-0.00165 \\
(0.0114)\end{array}$ & $\begin{array}{c}-0.00862 \\
(0.0158)\end{array}$ & $\begin{array}{r}-0.00381 \\
(0.0146)\end{array}$ \\
\hline Treat $x$ Days Since Event & $\begin{array}{l}-0.00717 \\
(0.00970)\end{array}$ & $\begin{array}{l}-0.00377 \\
(0.00975)\end{array}$ & $\begin{array}{l}-0.00387 \\
(0.00967)\end{array}$ & $\begin{array}{c}-0.000476 \\
(0.0103)\end{array}$ & $\begin{array}{c}-0.00624 \\
(0.0102)\end{array}$ \\
\hline Observations & 2,355 & 2,355 & 2,355 & 1,214 & 1,547 \\
\hline Country FE & $y$ & $y$ & $y$ & $y$ & $y$ \\
\hline Demographic Controls & $n$ & $y$ & $y$ & $y$ & $y$ \\
\hline Week FE & $n$ & $n$ & $y$ & $y$ & $y$ \\
\hline Includes Bordering Countries & $y$ & $y$ & $y$ & $y$ & $n$ \\
\hline Includes Non-Bordering Countries & $y$ & $y$ & $y$ & $n$ & $y$ \\
\hline
\end{tabular}


Table A14: Trend Analysis - (Engagement in (Informal) Social Networks Index)

\begin{tabular}{|c|c|c|c|c|c|}
\hline (A) [-68 days, 0 days $]$ & (1) & (2) & (3) & (4) & (5) \\
\hline \multirow[t]{2}{*}{ Days Since Event } & $0.00155^{*}$ & 0.00113 & 0.00442 & 0.00627 & 0.00301 \\
\hline & $(0.000861)$ & $(0.000831)$ & $(0.00490)$ & $(0.00693)$ & $(0.00600)$ \\
\hline \multirow[t]{2}{*}{ Treat $x$ Days Since Event } & 0.000320 & $-5.82 \mathrm{e}-05$ & -0.000528 & -0.00131 & -0.000895 \\
\hline & $(0.00290)$ & $(0.00284)$ & $(0.00296)$ & $(0.00319)$ & $(0.00316)$ \\
\hline Observations & 8,322 & 8,322 & 8,322 & 4,135 & 5,680 \\
\hline (B) [-47 days, 0 days $]$ & $(1)$ & (2) & (3) & (4) & $(5)$ \\
\hline \multirow[t]{2}{*}{ Days Since Event } & $0.00365^{* *}$ & $0.00342 * *$ & 0.00748 & 0.00995 & 0.000824 \\
\hline & $(0.00159)$ & $(0.00153)$ & $(0.00689)$ & $(0.00938)$ & $(0.00832)$ \\
\hline \multirow[t]{2}{*}{ Treat $x$ Days Since Event } & -0.00299 & -0.00283 & -0.00296 & -0.00356 & -0.00262 \\
\hline & $(0.00384)$ & $(0.00379)$ & $(0.00381)$ & $(0.00419)$ & $(0.00407)$ \\
\hline Observations & 5,116 & 5,116 & 5,116 & 2,796 & 3,552 \\
\hline (C) [-30 days, 0 days $]$ & (1) & (2) & (3) & (4) & $(5)$ \\
\hline \multirow[t]{2}{*}{ Days Since Event } & 0.00168 & 0.00186 & -0.00741 & 0.00532 & -0.0164 \\
\hline & $(0.00316)$ & $(0.00304)$ & $(0.0111)$ & $(0.0155)$ & $(0.0139)$ \\
\hline \multirow[t]{2}{*}{ Treat $x$ Days Since Event } & -0.0106 & -0.00492 & -0.00537 & -0.00343 & -0.00726 \\
\hline & $(0.00928)$ & $(0.00913)$ & $(0.00910)$ & $(0.00996)$ & $(0.00944)$ \\
\hline Observations & 2,355 & 2,355 & 2,355 & 1,214 & 1,547 \\
\hline Country FE & $y$ & $y$ & $y$ & $y$ & $y$ \\
\hline Demographic Controls & $n$ & $y$ & $y$ & $y$ & $y$ \\
\hline Week FE & $n$ & $n$ & $y$ & $y$ & $y$ \\
\hline Includes Bordering Countries & $y$ & $y$ & $y$ & $y$ & $n$ \\
\hline Includes Non-Bordering Countries & $y$ & $y$ & $y$ & $n$ & $y$ \\
\hline \multicolumn{6}{|c|}{$\begin{array}{l}\text { Notes: *** }<<0.01, * * \mathrm{p}<0.05, * \mathrm{p}<0.1 \text {. Robust (Huber-White) standard errors in parentheses. Columns (1) - (5) report } \\
\text { coefficient estimates of the treatment group by days since Charlie Hebdo interaction terms as specified in estimating } \\
\text { equation (2) with the Engagement in (Informal) Social Networks index as the dependent variable. The set of } \\
\text { demographic controls include: Second-order polynomials in age and education (in years); a binary variable indicating } \\
\text { if the respondent is female; and a set of categorical variables indicating the decile of the respondent's household's } \\
\text { total net income. }\end{array}$} \\
\hline
\end{tabular}


Table A15: Trend Analysis - (Values/Norms of Reciprocity Index)

\begin{tabular}{|c|c|c|c|c|c|}
\hline (A) [-68 days, 0 days $]$ & (1) & $(2)$ & (3) & (4) & (5) \\
\hline \multirow[t]{2}{*}{ Days Since Event } & 0.000996 & 0.000889 & -0.00475 & -0.00279 & -0.00466 \\
\hline & $(0.000868)$ & $(0.000861)$ & $(0.00517)$ & $(0.00732)$ & $(0.00661)$ \\
\hline \multirow{2}{*}{ Treat $\mathrm{x}$ Days Since Event } & 0.00105 & $8.46 \mathrm{e}-05$ & -0.000531 & 0.00241 & -0.00368 \\
\hline & $(0.00326)$ & $(0.00323)$ & $(0.00338)$ & $(0.00358)$ & $(0.00360)$ \\
\hline Observations & 8,322 & 8,322 & 8,322 & 4,135 & 5,680 \\
\hline (B) [-47 days, 0 days $]$ & $(1)$ & $(2)$ & (3) & (4) & $(5)$ \\
\hline \multirow[t]{2}{*}{ Days Since Event } & 0.00228 & 0.00230 & -0.00462 & -0.00462 & -0.0123 \\
\hline & $(0.00158)$ & $(0.00156)$ & $(0.00997)$ & $(0.00997)$ & $(0.00950)$ \\
\hline \multirow[t]{2}{*}{ Treat x Days Since Event } & 0.00122 & -0.000219 & 0.00508 & 0.00508 & -0.00526 \\
\hline & $(0.00440)$ & $(0.00433)$ & $(0.00465)$ & $(0.00465)$ & $(0.00463)$ \\
\hline Observations & 5,116 & 5,116 & 2,796 & 2,796 & 3,552 \\
\hline (C) [-30 days, 0 days $]$ & $(1)$ & $(2)$ & (3) & (4) & $(5)$ \\
\hline \multirow[t]{2}{*}{ Days Since Event } & 0.00264 & 0.00310 & -0.00622 & 0.00299 & -0.0160 \\
\hline & $(0.00306)$ & $(0.00306)$ & $(0.0121)$ & $(0.0168)$ & $(0.0161)$ \\
\hline \multirow[t]{2}{*}{ Treat $x$ Days Since Event } & -0.00793 & -0.00538 & -0.00597 & 0.00233 & -0.0120 \\
\hline & $(0.00913)$ & $(0.00917)$ & $(0.00928)$ & $(0.00982)$ & $(0.00974)$ \\
\hline Observations & 2,355 & 2,355 & 2,355 & 1,214 & 1,547 \\
\hline Country FE & $y$ & $y$ & $y$ & $y$ & $y$ \\
\hline Demographic Controls & $n$ & $y$ & $y$ & $y$ & $y$ \\
\hline Week FE & $n$ & $n$ & $y$ & $y$ & $y$ \\
\hline Includes Bordering Countries & $y$ & $y$ & $y$ & $y$ & $n$ \\
\hline Includes Non-Bordering Countries & $y$ & $y$ & $y$ & $n$ & $y$ \\
\hline \multicolumn{6}{|c|}{$\begin{array}{l}\text { Notes: *** }<<0.01, * * \mathrm{p}<0.05, * \mathrm{p}<0.1 \text {. Robust (Huber-White) standard errors in parentheses. Columns (1) - (5) } \\
\text { report coefficient estimates of the treatment group by days since Charlie Hebdo interaction terms as specified in } \\
\text { estimating equation (2) with the Values/Norms of Reciprocity index as the dependent variable. The set of } \\
\text { demographic controls include: Second-order polynomials in age and education (in years); a binary variable indicating } \\
\text { if the respondent is female; and a set of categorical variables indicating the decile of the respondent's household's } \\
\text { total net income. }\end{array}$} \\
\hline
\end{tabular}


Table A17: Heterogeneity Analysis (AI)

\begin{tabular}{lcccccc}
\hline Dependent Variable: & $\begin{array}{c}\text { Social } \\
\text { Capital }\end{array}$ & $\begin{array}{c}\text { Institutional } \\
\text { Trust }\end{array}$ & $\begin{array}{c}\text { Interpersonal } \\
\text { Trust }\end{array}$ & $\begin{array}{c}\text { Social } \\
\text { Networks }\end{array}$ & Reciprocity & $\begin{array}{c}\text { Ethnic } \\
\text { Tolerance }\end{array}$ \\
\hline (A) Gender & $(1)$ & $(2)$ & $(3)$ & $(4)$ & $(5)$ & $(6)$ \\
\hline Male x Treat x Post & $0.255^{* *}$ & $0.330^{* * *}$ & $0.192^{*}$ & 0.191 & 0.0229 & -0.103 \\
& $(0.106)$ & $(0.120)$ & $(0.103)$ & $(0.125)$ & $(0.112)$ & $(0.114)$ \\
Female x Treat x Post & $0.280^{* * *}$ & $0.291^{* * *}$ & $0.170^{*}$ & 0.0756 & 0.0921 & 0.129 \\
& $(0.0947)$ & $(0.0976)$ & $(0.0996)$ & $(0.112)$ & $(0.115)$ & $(0.0988)$ \\
Observations & 12,466 & 12,466 & 12,466 & 12,466 & 12,466 & 12,466 \\
Difference of Coefficients & -0.025 & 0.039 & 0.022 & 0.115 & -0.069 & -0.232 \\
P-Value & {$[0.856]$} & {$[0.796]$} & {$[0.875]$} & {$[0.484]$} & {$[0.661]$} & {$[0.113]$} \\
\hline (B) Age & $(1)$ & $(2)$ & $(3)$ & $(4)$ & $(5)$ & $(6)$ \\
\hline Old x Treat x Post & $0.200^{*}$ & $0.256^{* *}$ & 0.142 & 0.0479 & 0.0896 & -0.0263 \\
& $(0.108)$ & $(0.125)$ & $(0.0974)$ & $(0.113)$ & $(0.123)$ & $(0.134)$ \\
Young x Treat x Post & $0.341^{* * *}$ & $0.368^{* * *}$ & $0.212^{* * *}$ & $0.227 *$ & 0.0616 & 0.0240 \\
& $(0.0951)$ & $(0.100)$ & $(0.0989)$ & $(0.116)$ & $(0.108)$ & $(0.0926)$ \\
Observations & 12,466 & 12,466 & 12,466 & 12,466 & 12,466 & 12,466 \\
Difference of Coefficients & -0.140 & -0.112 & -0.069 & -0.179 & 0.028 & -0.050 \\
P-Value & {$[0.319]$} & {$[0.480]$} & {$[0.610]$} & {$[0.263]$} & {$[0.863]$} & {$[0.752]$} \\
\hline (C) Education & $(1)$ & $(2)$ & $(3)$ & $(4)$ & $(5)$ & $(6)$ \\
\hline Education(High) x Treat x Post & $0.262^{* * *}$ & $0.353^{* * *}$ & $0.217 * *$ & 0.175 & -0.0840 & 0.0140 \\
Education(Low) x Treat x Post & $(0.102)$ & $(0.110)$ & $(0.102)$ & $(0.132)$ & $(0.105)$ & $(0.0860)$ \\
Observations & $0.275^{* * *}$ & $0.286^{* * *}$ & 0.152 & 0.101 & 0.179 & -0.00401 \\
Difference of Coefficients & $(0.0999)$ & $(0.109)$ & $(0.101)$ & $(0.106)$ & $(0.123)$ & $(0.122)$ \\
P-Value & 12,466 & 12,466 & 12,466 & 12,466 & 12,466 & 12,466 \\
& -0.013 & 0.067 & 0.066 & 0.074 & -0.263 & 0.018 \\
& {$[0.927]$} & {$[0.662]$} & {$[0.641]$} & {$[0.656]$} & {$[0.099]$} & {$[0.902]$}
\end{tabular}

Notes: *** $\mathrm{p}<0.01, * * \mathrm{p}<0.05, * \mathrm{p}<0.1$. Robust (Huber-White) standard errors in parentheses. Columns (1) - (6) report coefficient estimates of the treatment group by post Charlie Hebdo interaction terms as specified in estimating equation (5) using the full sample of observations [-68 days, 47 days] and full sample of countries. Each model includes country fixed effects, week fixed effects, and demographic controls (second-order polynomials in age and education; a binary variable indicating if the respondent is female; and a set of categorical variables indicating the decile of the respondent's household's total net income). The social capital index of interest used on the left hand side of estimating equation (1) is reported in the column headings above the column numbers. The dimension of heterogeneity considered is given in each panel heading. 
Table A18: Heterogeneity Analysis (AII)

\begin{tabular}{|c|c|c|c|c|c|c|}
\hline Dependent Variable: & $\begin{array}{c}\text { Social } \\
\text { Capital } \\
\end{array}$ & $\begin{array}{c}\text { Institutional } \\
\text { Trust } \\
\end{array}$ & $\begin{array}{c}\text { Interpersonal } \\
\text { Trust } \\
\end{array}$ & $\begin{array}{c}\text { Social } \\
\text { Networks }\end{array}$ & Reciprocity & $\begin{array}{c}\text { Ethnic } \\
\text { Tolerance }\end{array}$ \\
\hline (A) Marital Status & $(1)$ & $(2)$ & (3) & (4) & $(5)$ & (6) \\
\hline Married x Treat x Post & $\begin{array}{l}0.220 * * \\
(0.106)\end{array}$ & $\begin{array}{l}0.306^{* *} \\
(0.124)\end{array}$ & $\begin{array}{c}0.146 \\
(0.108)\end{array}$ & $\begin{array}{c}0.110 \\
(0.135)\end{array}$ & $\begin{array}{l}-0.0419 \\
(0.117)\end{array}$ & $\begin{array}{l}0.0614 \\
(0.114)\end{array}$ \\
\hline Not Married x Treat x Post & $\begin{array}{c}0.332 * * * \\
(0.0953)\end{array}$ & $\begin{array}{r}0.314 * * * \\
(0.0916)\end{array}$ & $\begin{array}{l}0.223 * * \\
(0.0936)\end{array}$ & $\begin{array}{l}0.178^{*} \\
(0.101)\end{array}$ & $\begin{array}{c}0.160 \\
(0.113)\end{array}$ & $\begin{array}{l}-0.0134 \\
(0.0981)\end{array}$ \\
\hline Observations & 12,360 & 12,360 & 12,360 & 12,360 & 12,360 & 12,360 \\
\hline $\begin{array}{l}\text { Difference of Coefficients } \\
\text { P-Value }\end{array}$ & $\begin{array}{l}-0.113 \\
{[0.421]}\end{array}$ & $\begin{array}{l}-0.008 \\
{[0.957]}\end{array}$ & $\begin{array}{l}-0.077 \\
{[0.581]}\end{array}$ & $\begin{array}{l}-0.068 \\
{[0.680]}\end{array}$ & $\begin{array}{l}-0.202 \\
{[0.208]}\end{array}$ & $\begin{array}{c}0.075 \\
{[0.611]}\end{array}$ \\
\hline (B) Employment Status & $(1)$ & $(2)$ & (3) & (4) & $(5)$ & (6) \\
\hline Employed $x$ Treat $x$ Post & $\begin{array}{c}0.286 * * * \\
(0.0933)\end{array}$ & $\begin{array}{c}0.332 * * * \\
(0.102)\end{array}$ & $\begin{array}{l}0.200 * * \\
(0.0915)\end{array}$ & $\begin{array}{c}0.187 \\
(0.115)\end{array}$ & $\begin{array}{l}0.0242 \\
(0.104)\end{array}$ & $\begin{array}{c}-0.00562 \\
(0.0929)\end{array}$ \\
\hline Not Employed $x$ Treat $x$ Post & $\begin{array}{c}0.248^{* *} \\
(0.107)\end{array}$ & $\begin{array}{c}0.309 * * * \\
(0.115)\end{array}$ & $\begin{array}{c}0.164 \\
(0.115)\end{array}$ & $\begin{array}{l}0.0397 \\
(0.113)\end{array}$ & $\begin{array}{l}0.0889 \\
(0.132)\end{array}$ & $\begin{array}{l}0.0510 \\
(0.128)\end{array}$ \\
\hline $\begin{array}{l}\text { Observations } \\
\text { Difference of Coefficients } \\
\text { P-Value }\end{array}$ & $\begin{array}{c}12,442 \\
0.037 \\
{[0.789]}\end{array}$ & $\begin{array}{c}12,442 \\
0.023 \\
{[0.878]}\end{array}$ & $\begin{array}{c}12,442 \\
0.036 \\
{[0.803]}\end{array}$ & $\begin{array}{c}12,442 \\
0.147 \\
{[0.351]}\end{array}$ & $\begin{array}{c}12,442 \\
-0.065 \\
{[0.696]}\end{array}$ & $\begin{array}{c}12,442 \\
-0.057 \\
{[0.713]}\end{array}$ \\
\hline (C) Income & $(1)$ & $(2)$ & (3) & (4) & $(5)$ & $(6)$ \\
\hline High Income $x$ Treat $x$ Post & $\begin{array}{l}0.223 * * \\
(0.0956)\end{array}$ & $\begin{array}{c}0.338 * * * \\
(0.104)\end{array}$ & $\begin{array}{c}0.138 \\
(0.0944)\end{array}$ & $\begin{array}{l}0.0398 \\
(0.121)\end{array}$ & $\begin{array}{c}0.138 \\
(0.109)\end{array}$ & $\begin{array}{c}-0.106 \\
(0.0910)\end{array}$ \\
\hline Low Income $x$ Treat $x$ Post & $\begin{array}{c}0.345 * * * \\
(0.106)\end{array}$ & $\begin{array}{l}0.302 * * \\
(0.118)\end{array}$ & $\begin{array}{r}0.254 * * \\
(0.109)\end{array}$ & $\begin{array}{c}0.271 * * \\
(0.110)\end{array}$ & $\begin{array}{l}-0.0604 \\
(0.122)\end{array}$ & $\begin{array}{c}0.171 \\
(0.129)\end{array}$ \\
\hline Observations & 12,442 & 12,442 & 12,442 & 12,442 & 12,442 & 12,442 \\
\hline $\begin{array}{l}\text { Difference of Coefficients } \\
\text { P-Value }\end{array}$ & $\begin{array}{l}-0.122 \\
{[0.383]}\end{array}$ & $\begin{array}{c}0.036 \\
{[0.814]}\end{array}$ & $\begin{array}{l}-0.117 \\
{[0.408]}\end{array}$ & $\begin{array}{l}-0.231 \\
{[0.150]}\end{array}$ & $\begin{array}{c}0.199 \\
{[0.218]}\end{array}$ & $\begin{array}{l}-0.277 \\
{[0.072]}\end{array}$ \\
\hline
\end{tabular}

Notes: $* * * \mathrm{p}<0.01, * * \mathrm{p}<0.05, * \mathrm{p}<0.1$. Robust (Huber-White) standard errors in parentheses. Columns (1) - (6) report coefficient estimates of the treatment group by post Charlie Hebdo interaction terms as specified in estimating equation (5) using the full sample of observations [-68 days, 47 days] and full sample of countries. Each model includes country fixed effects, week fixed effects, and demographic controls (second-order polynomials in age and education; a binary variable indicating if the respondent is female; and a set of categorical variables indicating the decile of the respondent's household's total net income). The social capital index of interest used on the left hand side of estimating equation (5) is reported in the column headings above the column numbers. The dimension of heterogeneity considered is given in each panel heading. 
Table A19: Heterogeneity Analysis: French Respondents Born in France vs. French Respondents Not Born in France

\begin{tabular}{lcccccc}
\hline Dependent Variable: & $\begin{array}{c}\text { Social } \\
\text { Capital }\end{array}$ & $\begin{array}{c}\text { Institutional } \\
\text { Trust }\end{array}$ & $\begin{array}{c}\text { Interpersonal } \\
\text { Trust }\end{array}$ & $\begin{array}{c}\text { Social } \\
\text { Networks }\end{array}$ & Reciprocity & $\begin{array}{c}\text { Ethnic } \\
\text { Tolerance }\end{array}$ \\
\hline (A) [Full Sample] & $(1)$ & $(2)$ & $(3)$ & $(4)$ & $(5)$ & $(6)$ \\
\hline Born in France x Post & 0.0769 & 0.187 & 0.0427 & -0.327 & 0.323 & -0.0489 \\
& $(0.202)$ & $(0.282)$ & $(0.230)$ & $(0.237)$ & $(0.249)$ & $(0.280)$ \\
Observations & 1,765 & 1,765 & 1,765 & 1,765 & 1,765 & 1,765 \\
\hline (B) [-47 days, 47 days] & $(1)$ & $(2)$ & $(3)$ & $(4)$ & $(5)$ & $(6)$ \\
\hline Born in France x Post & 0.175 & 0.270 & 0.0939 & -0.308 & 0.398 & -0.0132 \\
& $(0.205)$ & $(0.283)$ & $(0.231)$ & $(0.241)$ & $(0.251)$ & $(0.287)$ \\
Observations & 1,504 & 1,504 & 1,504 & 1,504 & 1,504 & 1,504 \\
\hline (C) [-30 days, 30 days] & $(1)$ & $(2)$ & $(3)$ & $(4)$ & $(5)$ & $(6)$ \\
\hline Born in France x Post & 0.259 & 0.488 & 0.159 & -0.0711 & 0.201 & -0.154 \\
& $(0.263)$ & $(0.327)$ & $(0.303)$ & $(0.277)$ & $(0.286)$ & $(0.298)$ \\
Observations & 647 & 647 & 647 & 647 & 647 & 647 \\
\hline Demographic Controls & $y$ & $y$ & $y$ & $y$ & $y$ & $y$ \\
Week FE & $y$ & $y$ & $y$ & $y$ & $y$ & $y$ \\
\hline
\end{tabular}

Notes: $* * * \mathrm{p}<0.01, * * \mathrm{p}<0.05, * \mathrm{p}<0.1$. Robust (Huber-White) standard errors in parentheses. Columns (1) - (6) report coefficient estimates of the treatment group by post Charlie Hebdo interaction term as specified in estimating equation (1) defining the set of French respondents born in France as the treatment group (e.g. Born in France $=1$ ) and the set of French respondents not born in France as the control group (e.g. Born in France $=0$ ). Columns (1)-(6) exclude all countries other than France from the estimation. Finally, the social capital index of interest used on the left hand side of estimating equation (1) is reported in the column headings above the column numbers. The set of demographic controls include: Second-order polynomials in age and education (in years); a binary variable indicating if the respondent is female; and a set of categorical variables indicating the decile of the respondent's household's total net income. 
Table A20: Heterogeneity Analysis: Distance to the Attack

\begin{tabular}{|c|c|c|c|c|c|c|}
\hline Dependent Variable: & $\begin{array}{c}\text { Social } \\
\text { Capital } \\
\end{array}$ & $\begin{array}{c}\text { Institutional } \\
\text { Trust } \\
\end{array}$ & $\begin{array}{c}\text { Interpersonal } \\
\text { Trust } \\
\end{array}$ & $\begin{array}{c}\text { Social } \\
\text { Networks } \\
\end{array}$ & Reciprocity & $\begin{array}{c}\text { Ethnic } \\
\text { Tolerance } \\
\end{array}$ \\
\hline (A) [Full Sample] & $(1)$ & $(2)$ & (3) & (4) & $(5)$ & (6) \\
\hline Distance to Attack x Post & $\begin{array}{c}3.59 \mathrm{e}-07 \\
(3.77 \mathrm{e}-07)\end{array}$ & $\begin{array}{c}3.68 \mathrm{e}-07 \\
(3.75 \mathrm{e}-07)\end{array}$ & $\begin{array}{l}-2.88 \mathrm{e}-07 \\
(3.42 \mathrm{e}-07)\end{array}$ & $\begin{array}{c}1.12 \mathrm{e}-07 \\
(4.18 \mathrm{e}-07)\end{array}$ & $\begin{array}{c}5.68 \mathrm{e}-07 \\
(4.05 \mathrm{e}-07)\end{array}$ & $\begin{array}{c}2.87 \mathrm{e}-07 \\
(4.49 \mathrm{e}-07)\end{array}$ \\
\hline Observations & 1,765 & 1,765 & 1,765 & 1,765 & 1,765 & 1,765 \\
\hline (B) [-47 days, 47 days] & $(1)$ & $(2)$ & (3) & (4) & $(5)$ & (6) \\
\hline Distance to Attack x Post & $\begin{array}{c}3.13 \mathrm{e}-07 \\
(3.87 \mathrm{e}-07)\end{array}$ & $\begin{array}{c}2.82 \mathrm{e}-07 \\
(3.84 \mathrm{e}-07)\end{array}$ & $\begin{array}{l}-2.73 \mathrm{e}-07 \\
(3.50 \mathrm{e}-07)\end{array}$ & $\begin{array}{c}4.55 \mathrm{e}-08 \\
(4.22 \mathrm{e}-07)\end{array}$ & $\begin{array}{c}6.12 \mathrm{e}-07 \\
(4.11 \mathrm{e}-07)\end{array}$ & $\begin{array}{c}2.48 \mathrm{e}-07 \\
(4.67 \mathrm{e}-07)\end{array}$ \\
\hline Observations & 1,504 & 1,504 & 1,504 & 1,504 & 1,504 & 1,504 \\
\hline (C) [-30 days, 30 days] & $(1)$ & $(2)$ & (3) & (4) & $(5)$ & (6) \\
\hline Distance to Attack x Post & $\begin{array}{l}-7.05 e-08 \\
(4.84 e-07)\end{array}$ & $\begin{array}{c}4.16 \mathrm{e}-07 \\
(4.76 \mathrm{e}-07)\end{array}$ & $\begin{array}{l}-4.94 \mathrm{e}-07 \\
(4.36 \mathrm{e}-07)\end{array}$ & $\begin{array}{l}-8.64 \mathrm{e}-08 \\
(5.03 \mathrm{e}-07)\end{array}$ & $\begin{array}{l}-6.93 e-08 \\
(5.18 \mathrm{e}-07)\end{array}$ & $\begin{array}{c}8.41 \mathrm{e}-08 \\
(5.18 \mathrm{e}-07)\end{array}$ \\
\hline Observations & 647 & 647 & 647 & 647 & 647 & 647 \\
\hline Region FE & $y$ & $y$ & $y$ & $y$ & $y$ & $y$ \\
\hline Demographic Controls & $y$ & $y$ & $y$ & $y$ & $y$ & $y$ \\
\hline Week FE & $y$ & $y$ & $y$ & $y$ & $y$ & $y$ \\
\hline
\end{tabular}

Notes: $* * * \mathrm{p}<0.01, * * \mathrm{p}<0.05, * \mathrm{p}<0.1$. Robust (Eicker-Huber-White) standard errors shown in parentheses. Columns (1) (6) report coefficient estimates of the treatment group by post Charlie Hebdo interaction terms as specified in estimating equation (1) replacing the treatment indicator with Distance to Attack (which measures the distance from the centroid of each region in France to the terrorist attack), restricting attention to France, and including region fixed effects. The social capital index of interest used on the left hand side of estimating equation (1) is reported in the column headings above the column numbers. The set of demographic controls include: Second-order polynomials in age and education (in years); a binary variable indicating if the respondent is female; and a set of categorical variables indicating the decile of the respondent's household's total net income. 
Table A21: DID Estimates: Spillover Effects

\begin{tabular}{lcccccc}
\hline Dependent Variable: & $\begin{array}{c}\text { Social } \\
\text { Capital }\end{array}$ & $\begin{array}{c}\text { Institutional } \\
\text { Trust }\end{array}$ & $\begin{array}{c}\text { Interpersonal } \\
\text { Trust }\end{array}$ & $\begin{array}{c}\text { Social } \\
\text { Networks }\end{array}$ & Reciprocity & $\begin{array}{c}\text { Ethnic } \\
\text { Tolerance }\end{array}$ \\
\hline (A) [Full Sample] & $(1)$ & $(2)$ & $(3)$ & $(4)$ & $(5)$ & $(6)$ \\
\hline I(Bordering Country) x Post & 0.0360 & 0.0703 & 0.0544 & -0.0440 & -0.0341 & 0.0538 \\
& $(0.0581)$ & $(0.0568)$ & $(0.0576)$ & $(0.0567)$ & $(0.0584)$ & $(0.0553)$ \\
Observations & 10,701 & 10,701 & 10,701 & 10,701 & 10,701 & 10,701 \\
\hline (B) [-47 days, 47 days] & $(1)$ & $(2)$ & $(3)$ & $(4)$ & $(5)$ & $(6)$ \\
\hline I(Bordering Country) x Post & 0.00943 & 0.0610 & 0.0136 & -0.0339 & -0.0223 & 0.00271 \\
& $(0.0635)$ & $(0.0623)$ & $(0.0629)$ & $(0.0619)$ & $(0.0641)$ & $(0.0608)$ \\
Observations & 7,756 & 7,756 & 7,756 & 7,756 & 7,756 & 7,756 \\
\hline (C) [-30 days, 30 days] & $(1)$ & $(2)$ & $(3)$ & $(4)$ & $(5)$ & $(6)$ \\
\hline I(Bordering Country) x Post & 0.0735 & 0.113 & 0.0506 & -0.0795 & 0.0741 & 0.0371 \\
& $(0.0771)$ & $(0.0747)$ & $(0.0752)$ & $(0.0758)$ & $(0.0787)$ & $(0.0716)$ \\
Observations & 5,104 & 5,104 & 5,104 & 5,104 & 5,104 & 5,104 \\
\hline Country FE & $y$ & $y$ & $y$ & $y$ & $y$ & $y$ \\
Demographic Controls & $y$ & $y$ & $y$ & $y$ & $y$ & $y$ \\
Week FE & $y$ & $y$ & $y$ & $y$ & $y$ & $y$ \\
Includes France & $n$ & $n$ & $n$ & $n$ & $n$ & $n$ \\
Includes Bordering Countries & $y$ & $y$ & $y$ & $y$ & $y$ & $y$ \\
Includes Non-Bordering Countries & $y$ & $y$ & $y$ & $y$ & $y$ & $y$ \\
\hline
\end{tabular}

Notes: $* * * \mathrm{p}<0.01, * * \mathrm{p}<0.05, * \mathrm{p}<0.1$. Robust (Huber-White) standard errors in parentheses. Columns (1) - (6) report coefficient estimates of the treatment group by post Charlie Hebdo interaction term as specified in estimating equation (1) defining the set of countries which border France as the treatment group (e.g. I(Bordering Country) = 1) and the set of nonbordering countries as the control group (e.g. I(Bordering Country) $=0)$. Columns (1)-(6) exclude France from the estimation. Finally, the social capital index of interest used on the left hand side of estimating equation (1) is reported in the column headings above the column numbers. The set of demographic controls include: Second-order polynomials in age and education (in years); a binary variable indicating if the respondent is female; and a set of categorical variables indicating the decile of the respondent's household's total net income. 
Table A22: Regression Discontinuity Estimates

\begin{tabular}{|c|c|c|c|c|c|c|}
\hline Dependent Variable: & $\begin{array}{c}\text { Social } \\
\text { Capital }\end{array}$ & $\begin{array}{c}\text { Institutional } \\
\text { Trust }\end{array}$ & $\begin{array}{c}\text { Interpersonal } \\
\text { Trust } \\
\end{array}$ & $\begin{array}{c}\text { Social } \\
\text { Networks } \\
\end{array}$ & Reciprocity & $\begin{array}{c}\text { Ethnic } \\
\text { Tolerance } \\
\end{array}$ \\
\hline (A) [Full Sample] & $(1)$ & (2) & (3) & (4) & (5) & (6) \\
\hline Post & $\begin{array}{c}0.473 * * * \\
(0.153)\end{array}$ & $\begin{array}{c}0.402 * * * \\
(0.153)\end{array}$ & $\begin{array}{c}0.393 * * * \\
(0.146)\end{array}$ & $\begin{array}{c}0.241 \\
(0.157)\end{array}$ & $\begin{array}{l}0.0899 \\
(0.176)\end{array}$ & $\begin{array}{c}0.131 \\
(0.147)\end{array}$ \\
\hline Days Since & $\begin{array}{l}-0.000998 \\
(0.00294)\end{array}$ & $\begin{array}{c}0.00138 \\
(0.00287)\end{array}$ & $\begin{array}{l}-0.00370 \\
(0.00297)\end{array}$ & $\begin{array}{l}0.000883 \\
(0.00270)\end{array}$ & $\begin{array}{l}0.000609 \\
(0.00309)\end{array}$ & $\begin{array}{l}-0.00208 \\
(0.00265)\end{array}$ \\
\hline Days Since x Post & $\begin{array}{l}-0.00937 \\
(0.00582)\end{array}$ & $\begin{array}{l}-0.0107^{*} \\
(0.00614)\end{array}$ & $\begin{array}{l}-0.00392 \\
(0.00562)\end{array}$ & $\begin{array}{c}-0.00707 \\
(0.00666)\end{array}$ & $\begin{array}{l}-0.00156 \\
(0.00709)\end{array}$ & $\begin{array}{l}-0.00163 \\
(0.00563)\end{array}$ \\
\hline Observations & 1,765 & 1,765 & 1,765 & 1,765 & 1,765 & 1,765 \\
\hline (B) [-47 days, 47 days] & $(1)$ & (2) & (3) & $(4)$ & $(5)$ & $(6)$ \\
\hline Post & $\begin{array}{c}0.373^{* *} \\
(0.170)\end{array}$ & $\begin{array}{c}0.241 \\
(0.164)\end{array}$ & $\begin{array}{c}0.353^{* * *} \\
(0.158)\end{array}$ & $\begin{array}{c}0.243 \\
(0.169)\end{array}$ & $\begin{array}{l}0.0506 \\
(0.190)\end{array}$ & $\begin{array}{c}0.103 \\
(0.155)\end{array}$ \\
\hline Days Since & $\begin{array}{c}0.00254 \\
(0.00387)\end{array}$ & $\begin{array}{c}0.00699 * * \\
(0.00350)\end{array}$ & $\begin{array}{l}-0.00230 \\
(0.00364)\end{array}$ & $\begin{array}{l}0.000734 \\
(0.00344)\end{array}$ & $\begin{array}{c}0.00225 \\
(0.00397)\end{array}$ & $\begin{array}{l}-0.00126 \\
(0.00325)\end{array}$ \\
\hline Days Since x Post & $\begin{array}{c}-0.0129 * * \\
(0.00633)\end{array}$ & $\begin{array}{c}-0.0163 * * \\
(0.00642)\end{array}$ & $\begin{array}{l}-0.00528 \\
(0.00598)\end{array}$ & $\begin{array}{l}-0.00677 \\
(0.00698)\end{array}$ & $\begin{array}{l}-0.00344 \\
(0.00749)\end{array}$ & $\begin{array}{l}-0.00230 \\
(0.00601)\end{array}$ \\
\hline Observations & 1,504 & 1,504 & 1,504 & 1,504 & 1,504 & 1,504 \\
\hline (C) [-30 days, 30 days] & $(1)$ & (2) & (3) & (4) & $(5)$ & (6) \\
\hline Post & $\begin{array}{c}0.612 * * \\
(0.258)\end{array}$ & $\begin{array}{c}0.348 \\
(0.238)\end{array}$ & $\begin{array}{l}0.480 * \\
(0.252)\end{array}$ & $\begin{array}{l}0.468^{*} \\
(0.247)\end{array}$ & $\begin{array}{c}0.255 \\
(0.259)\end{array}$ & $\begin{array}{l}0.0645 \\
(0.189)\end{array}$ \\
\hline Days Since & $\begin{array}{l}-0.00262 \\
(0.00962)\end{array}$ & $\begin{array}{c}0.00602 \\
(0.00857)\end{array}$ & $\begin{array}{l}-0.00414 \\
(0.00949)\end{array}$ & $\begin{array}{l}-0.00662 \\
(0.00898)\end{array}$ & $\begin{array}{l}-0.00440 \\
(0.00879)\end{array}$ & $\begin{array}{c}0.00261 \\
(0.00610)\end{array}$ \\
\hline Days Since x Post & $\begin{array}{c}-0.0189^{*} \\
(0.0114)\end{array}$ & $\begin{array}{c}-0.0221^{* *} \\
(0.0113)\end{array}$ & $\begin{array}{l}-0.0116 \\
(0.0115)\end{array}$ & $\begin{array}{r}-0.00501 \\
(0.0122)\end{array}$ & $\begin{array}{c}-0.00371 \\
(0.0117)\end{array}$ & $\begin{array}{l}-0.00853 \\
(0.00850)\end{array}$ \\
\hline Observations & 647 & 647 & 647 & 647 & 647 & 647 \\
\hline
\end{tabular}

Notes: $* * * \mathrm{p}<0.01, * * \mathrm{p}<0.05, * \mathrm{p}<0.1$. Robust (Huber-White) standard errors in parentheses. Columns (1) - (6) report coefficient estimates of estimating equation (6). The social capital index of interest used on the left hand side of estimating equation (6) is reported in the column headings above the column numbers. The set of demographic controls include: Second-order polynomials in age and education (in years); a binary variable indicating if the respondent is female; and a set of categorical variables indicating the decile of the respondent's household's total net income. 
Table A23: DID Estimates (Attitudes Towards Immigration)

\begin{tabular}{lccccc}
\hline (A) [Full Sample] & $(1)$ & $(2)$ & $(3)$ & $(4)$ & $(5)$ \\
\hline Treat x Post & $0.190^{* *}$ & 0.113 & 0.126 & 0.0441 & $0.155^{*}$ \\
& $(0.0824)$ & $(0.0825)$ & $(0.0839)$ & $(0.0940)$ & $(0.0869)$ \\
Observations & 12,466 & 12,466 & 12,466 & 6,154 & 8,077 \\
\hline (B) [-47 days, 47 days] & $(1)$ & $(2)$ & $(3)$ & $(4)$ & $(5)$ \\
\hline Treat x Post & $0.210^{* *}$ & 0.138 & $0.147^{*}$ & 0.0862 & $0.165^{*}$ \\
& $(0.0847)$ & $(0.0845)$ & $(0.0859)$ & $(0.0967)$ & $(0.0894)$ \\
Observations & 9,260 & 9,260 & 9,260 & 4,815 & 5,949 \\
\hline C) [-30 days, 30 days] & $(1)$ & $(2)$ & $(3)$ & $(4)$ & $(5)$ \\
\hline Treat x Post & $0.199^{*}$ & 0.161 & 0.161 & 0.125 & 0.164 \\
& $(0.108)$ & $(0.106)$ & $(0.107)$ & $(0.118)$ & $(0.111)$ \\
Observations & 5,751 & 5,751 & 5,751 & 2,752 & 3,646 \\
\hline Country FE & $y$ & $y$ & $y$ & $y$ & $y$ \\
Demographic Controls & $n$ & $y$ & $y$ & $y$ & $y$ \\
Week FE & $n$ & $n$ & $y$ & $y$ & $y$ \\
Includes Bordering Countries & $y$ & $y$ & $y$ & $y$ & $n$ \\
Includes Non-Bordering Countries & $y$ & $y$ & $y$ & $n$ & $y$ \\
\hline N & $y$
\end{tabular}

Notes: $* * * \mathrm{p}<0.01, * * \mathrm{p}<0.05, * \mathrm{p}<0.1$. Robust (Huber-White) standard errors in parentheses. Columns (1) (5) report coefficient estimates of the treatment group by post Charlie Hebdo interaction terms as specified in estimating equation (1) with the Attitudes Towards Immigrants index as the dependent variable. The set of demographic controls include: Second-order polynomials in age and education (in years); a binary variable indicating if the respondent is female; and a set of categorical variables indicating the decile of the respondent's household's total net income. 
Table A24: DID Estimates of the 2016 Berlin Christmas Attack

\begin{tabular}{|c|c|c|c|c|c|}
\hline Dependent Variable: & $\begin{array}{c}\text { Social } \\
\text { Capital } \\
\end{array}$ & $\begin{array}{c}\text { Institutional } \\
\text { Trust }\end{array}$ & $\begin{array}{c}\text { Interpersonal } \\
\text { Trust }\end{array}$ & $\begin{array}{c}\text { Social } \\
\text { Networks }\end{array}$ & Reciprocity \\
\hline (A) [Full Sample] & $(1)$ & (2) & (3) & (4) & (5) \\
\hline Treat $\mathrm{x}$ Post & $\begin{array}{l}-0.0200 \\
(0.0589)\end{array}$ & $\begin{array}{l}-0.0257 \\
(0.0569)\end{array}$ & $\begin{array}{l}-0.0762 \\
(0.0612)\end{array}$ & $\begin{array}{c}0.0586 \\
(0.0590)\end{array}$ & $\begin{array}{l}0.00247 \\
(0.0587)\end{array}$ \\
\hline Observations & 28,025 & 28,025 & 28,025 & 28,025 & 28,025 \\
\hline (B) [-68 days, 47 days] & $(1)$ & (2) & (3) & (4) & (5) \\
\hline Treat $x$ Post & $\begin{array}{l}-0.0341 \\
(0.0645)\end{array}$ & $\begin{array}{l}-0.0505 \\
(0.0642)\end{array}$ & $\begin{array}{l}-0.0739 \\
(0.0655)\end{array}$ & $\begin{array}{c}0.0242 \\
(0.0637)\end{array}$ & $\begin{array}{c}0.0245 \\
(0.0655)\end{array}$ \\
\hline Observations & 19,392 & 19,392 & 19,392 & 19,392 & 19,392 \\
\hline (C) [-47 days, 47 days] & $(1)$ & $(2)$ & (3) & (4) & (5) \\
\hline Treat $\mathrm{x}$ Post & $\begin{array}{l}-0.0366 \\
(0.0665)\end{array}$ & $\begin{array}{l}-0.0542 \\
(0.0663)\end{array}$ & $\begin{array}{l}-0.0742 \\
(0.0675)\end{array}$ & $\begin{array}{c}0.0229 \\
(0.0661)\end{array}$ & $\begin{array}{c}0.0237 \\
(0.0675)\end{array}$ \\
\hline Observations & 14,972 & 14,972 & 14,972 & 14,972 & 14,972 \\
\hline (D) [-30 days, 30 days] & $(1)$ & $(2)$ & (3) & (4) & $(5)$ \\
\hline Treat $x$ Post & $\begin{array}{l}-0.0203 \\
(0.0825)\end{array}$ & $\begin{array}{l}-0.0431 \\
(0.0816)\end{array}$ & $\begin{array}{l}-0.0273 \\
(0.0846)\end{array}$ & $\begin{array}{c}0.0310 \\
(0.0815)\end{array}$ & $\begin{array}{r}-0.00630 \\
(0.0849)\end{array}$ \\
\hline Observations & 8,465 & 8,465 & 8,465 & 8,465 & 8,465 \\
\hline Country FE & $y$ & $y$ & $y$ & $y$ & $y$ \\
\hline Demographic Controls & $y$ & $y$ & $y$ & $y$ & $y$ \\
\hline Week FE & $y$ & $y$ & $y$ & $y$ & $y$ \\
\hline
\end{tabular}

Notes: ${ }^{* * *} \mathrm{p}<0.01,{ }^{* *} \mathrm{p}<0.05,{ }^{*} \mathrm{p}<0.1$. Robust (Huber-White) standard errors in parentheses. Columns (1) - (5) report coefficient estimates of the treatment group by post event interaction terms as specified in estimating equation (1). The variable Treat is set equal to one for Germany and zero otherwise. Likewise, the variable Post is set equal to one for any period time after the Berlin Christmas Market Attack. The social capital index of interest used on the left hand side of estimating equation (1) is reported in the column headings. The set of demographic controls include: Second-order polynomials in age and education (in years); a binary variable indicating if the respondent is female; and a set of categorical variables indicating the decile of the respondent's household's total net income. Panel (A) reports estimates using the full sample of observations which span -112 to 88 days since the event. 
Table A25: Global Terrorism Analysis

\begin{tabular}{|c|c|c|c|c|}
\hline (A) Social Capital & $(1)$ & (2) & (3) & (4) \\
\hline Terrorism & $\begin{array}{c}0.0185 * * * \\
(0.00323)\end{array}$ & $\begin{array}{c}0.00891 * * \\
(0.00359)\end{array}$ & $\begin{array}{c}0.00860 * * \\
(0.00342)\end{array}$ & $\begin{array}{c}0.0195 * * * \\
(0.00519)\end{array}$ \\
\hline Observations & 49,312 & 49,312 & 49,312 & 49,312 \\
\hline (B) Institutional Trust & (1) & (2) & (3) & (4) \\
\hline Terrorism & $\begin{array}{c}0.0411^{* * * *} \\
(0.00695)\end{array}$ & $\begin{array}{c}0.0213 * * * \\
(0.00778)\end{array}$ & $\begin{array}{c}0.0203 * * * * \\
(0.00759)\end{array}$ & $\begin{array}{c}0.0477 * * * \\
(0.0126)\end{array}$ \\
\hline Observations & 49,312 & 49,312 & 49,312 & 49,312 \\
\hline (C) Interpersonal Trust & $(1)$ & (2) & (3) & (4) \\
\hline Terrorism & $\begin{array}{c}0.0308 * * * * \\
(0.00657)\end{array}$ & $\begin{array}{c}0.0110 \\
(0.00733)\end{array}$ & $\begin{array}{c}0.00866 \\
(0.00714)\end{array}$ & $\begin{array}{c}0.0255^{* * *} \\
(0.0110)\end{array}$ \\
\hline Observations & 49,312 & 49,312 & 49,312 & 49,312 \\
\hline (D) Social Networks & $(1)$ & $(2)$ & (3) & (4) \\
\hline Terrorism & $\begin{array}{c}0.0197 * * * * \\
(0.00687)\end{array}$ & $\begin{array}{c}0.00573 \\
(0.00767)\end{array}$ & $\begin{array}{c}0.00719 \\
(0.00741)\end{array}$ & $\begin{array}{l}0.0233^{*} \\
(0.0128)\end{array}$ \\
\hline Observations & 49,312 & 49,312 & 49,312 & 49,312 \\
\hline (E) Reciprocity & $(1)$ & (2) & (3) & (4) \\
\hline Terrorism & $\begin{array}{c}0.00345 \\
(0.00714)\end{array}$ & $\begin{array}{c}0.00787 \\
(0.00788)\end{array}$ & $\begin{array}{c}0.00841 \\
(0.00778)\end{array}$ & $\begin{array}{l}0.00379 \\
(0.0125)\end{array}$ \\
\hline Observations & 49,312 & 49,312 & 49,312 & 49,312 \\
\hline Country FE & $y$ & $y$ & $y$ & $y$ \\
\hline Year FE & $n$ & $y$ & $y$ & $n$ \\
\hline Demographic Controls & $n$ & $n$ & $y$ & $y$ \\
\hline Country Specific Time Trends & $n$ & $n$ & $n$ & $y$ \\
\hline
\end{tabular}

Notes: *** $p<0.01, * * p<0.05, * p<0.1$. Robust (Huber-White) standard errors in parentheses. Columns (1) - (4) report coefficient estimates of equation (6). The dependent variable of interest is indicated in each panel heading. 
Figure A1: Temporal Dynamics - (Social Capital Index): Robustness to Functional Form

(a) Linear

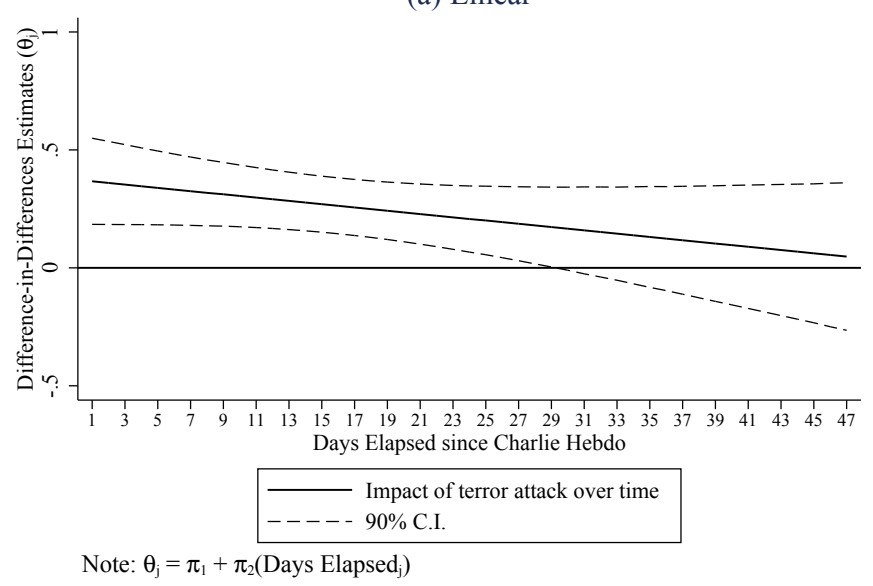

(b) Quadratic

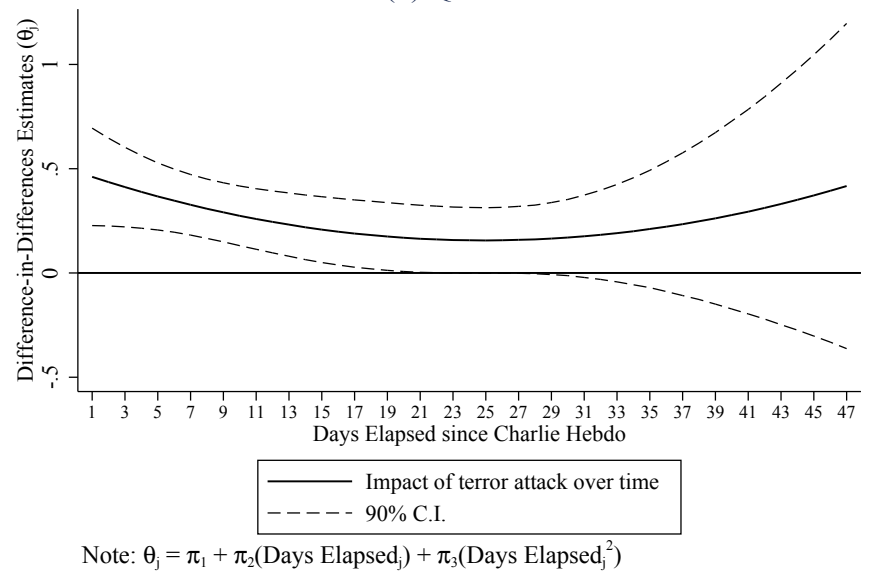

(c) Square Root

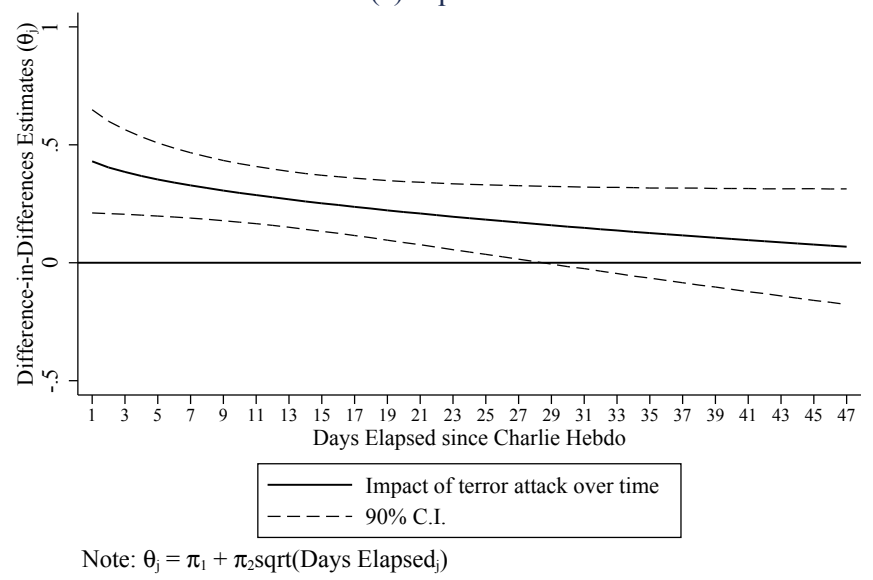


Figure A2: Temporal Dynamics - (Trust in Institutions Index): Robustness to Functional Form

(a) Linear

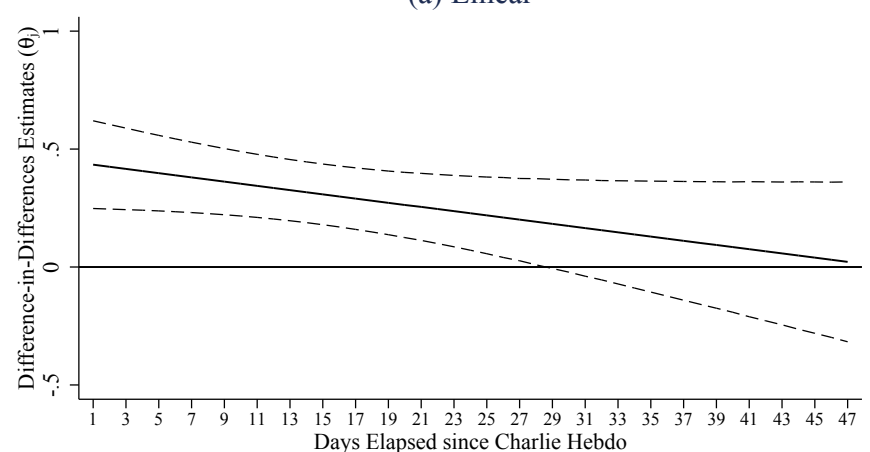

Impact of terror attack over time - - - - 90\% C.I.

Note: $\theta_{\mathrm{j}}=\pi_{1}+\pi_{2}\left(\right.$ Days Elapsed $\left._{\mathrm{j}}\right)$

(b) Quadratic

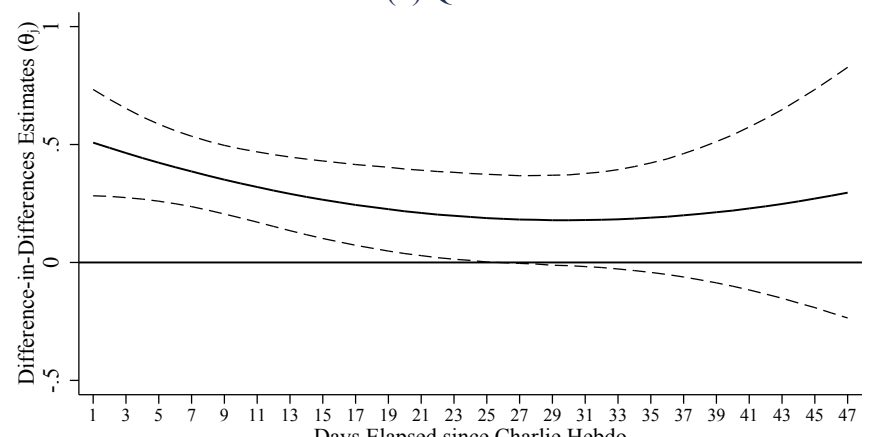

Days Elapsed since Charlie Hebdo

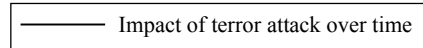
- - - - 90\% C.I.

Note: $\theta_{j}=\pi_{1}+\pi_{2}\left(\right.$ Days Elapsed $\left._{j}\right)+\pi_{3}\left(\right.$ Days Elapsed $\left._{j}^{2}\right)$

(c) Square Root

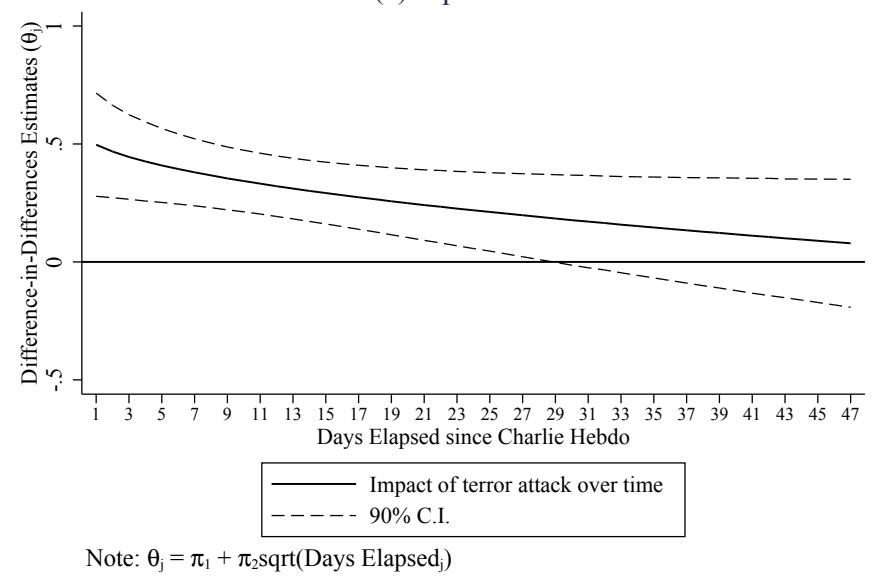


Figure A3: Temporal Dynamics - (Interpersonal Trust Index): Robustness to Functional Form

(a) Linear

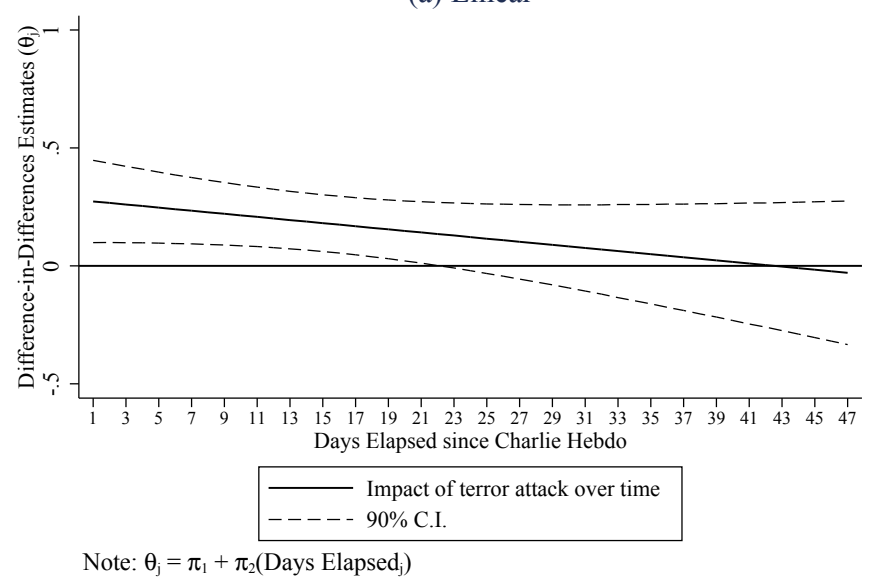

(b) Quadratic

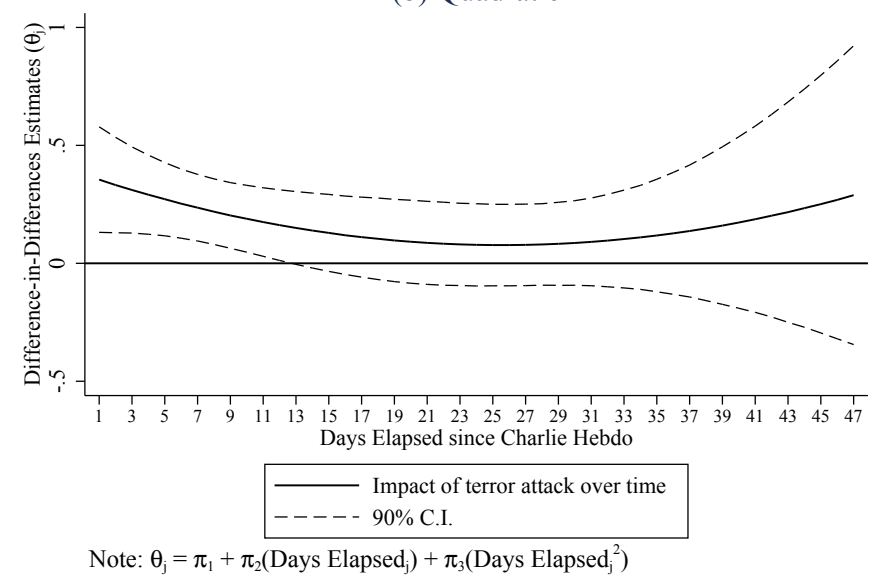

(c) Square Root

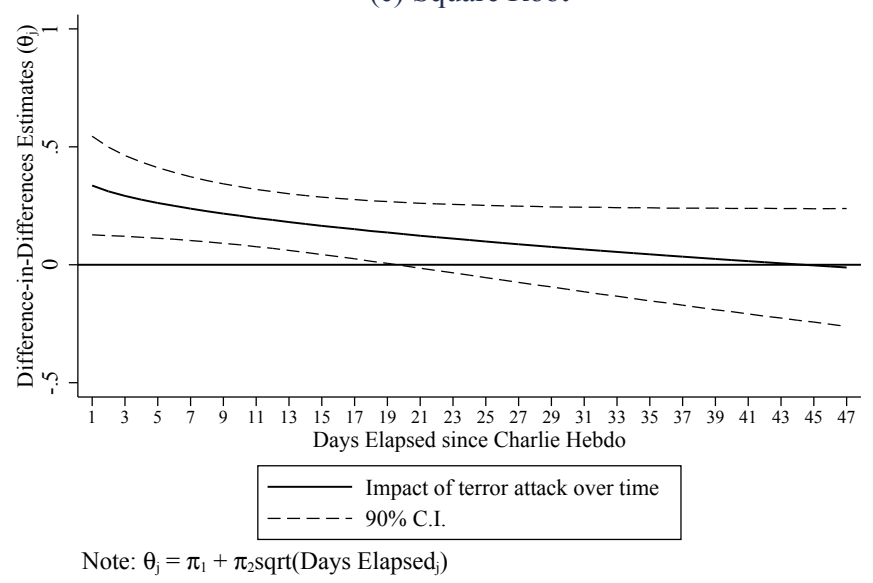


Figure A4: Temporal Dynamics - (Engagement in (Informal) Social Networks Index): Robustness to Functional Form

(a) Linear

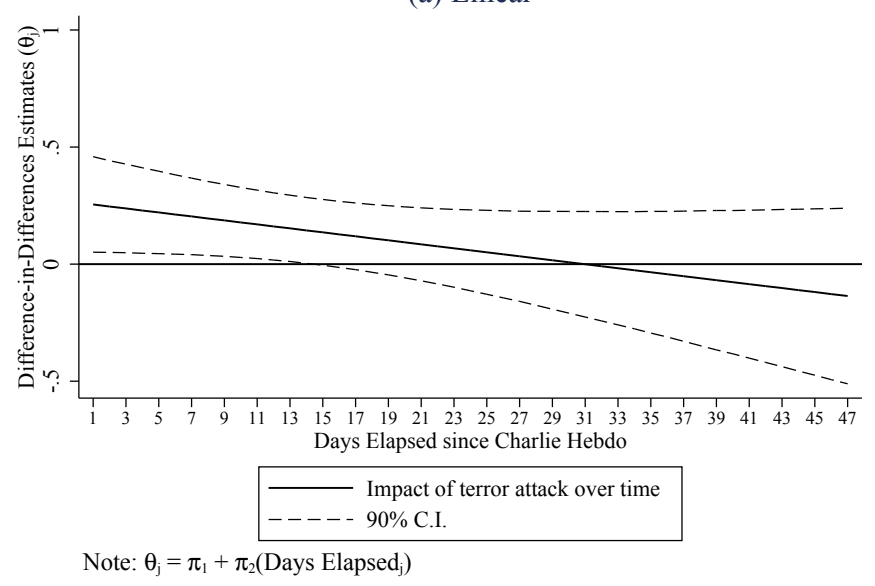

(b) Quadratic

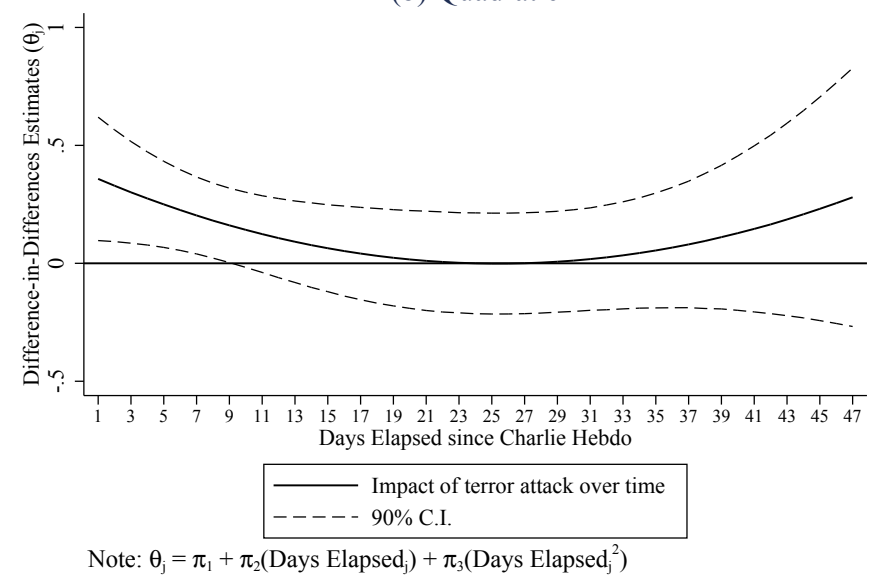

(c) Square Root

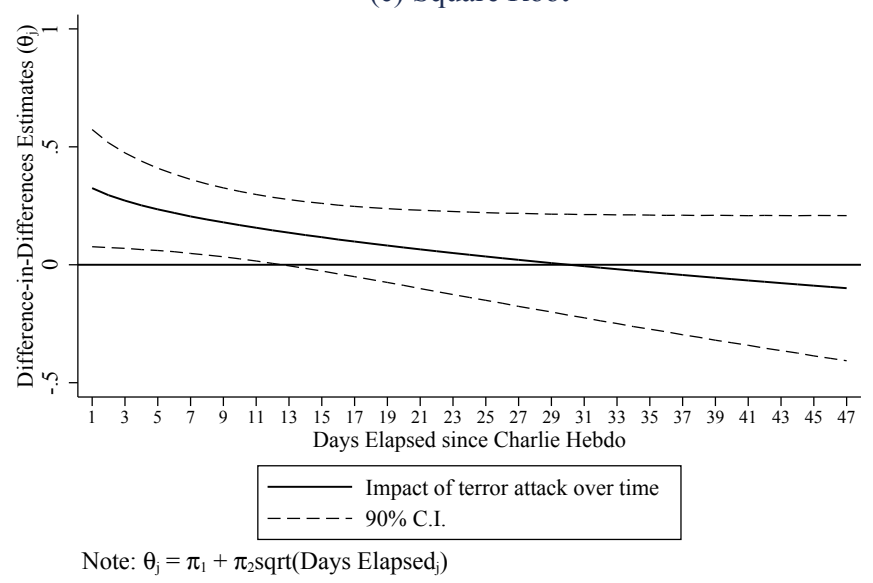


Figure A5: Temporal Dynamics - (Values/Norms of Reciprocity Index): Robustness to Functional Form

(a) Linear

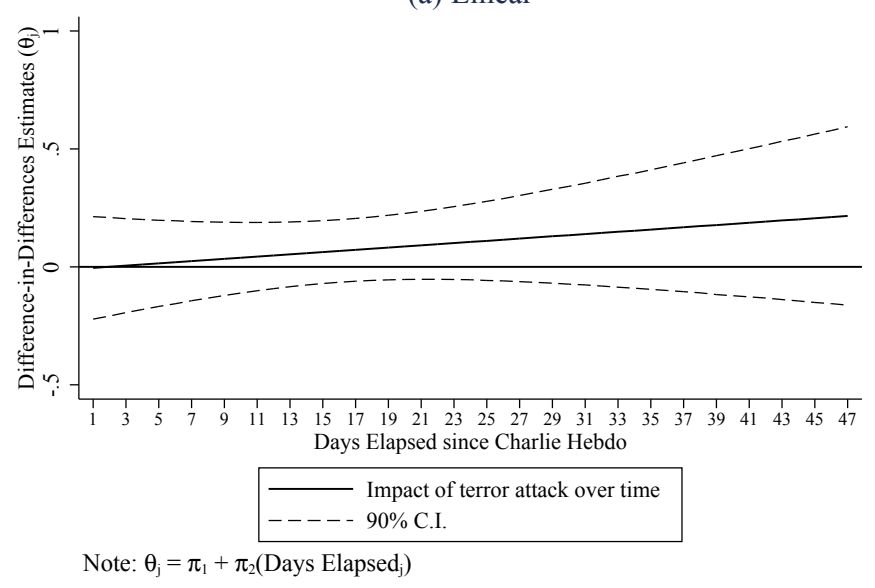

(b) Quadratic

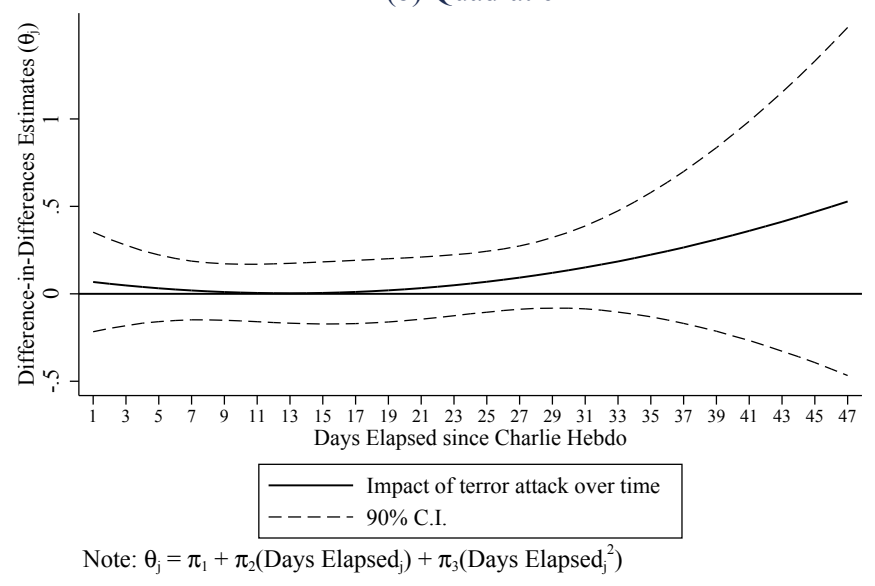

(c) Square Root

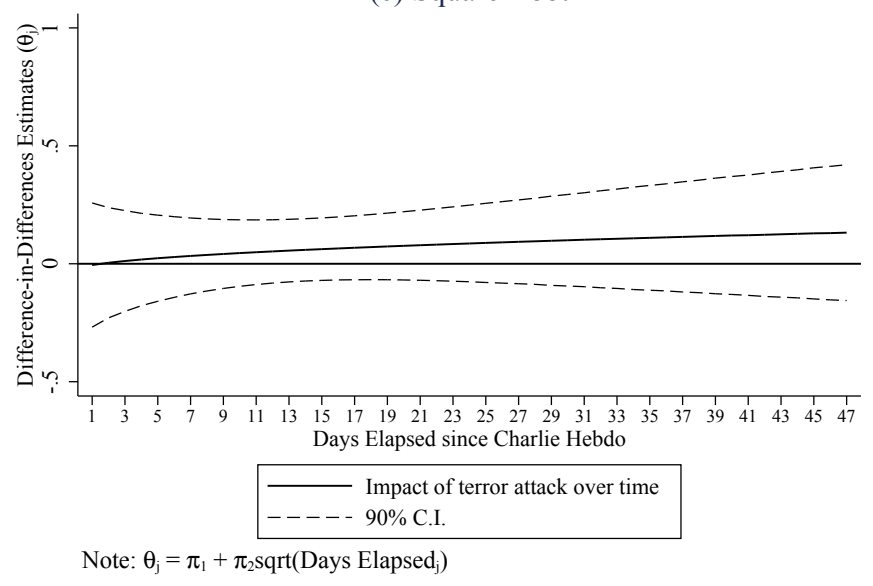


Figure A6: Temporal Dynamics - (Ethnic Tolerance/Tolerance of Diversity Index)): Robustness to Functional Form

(a) Linear

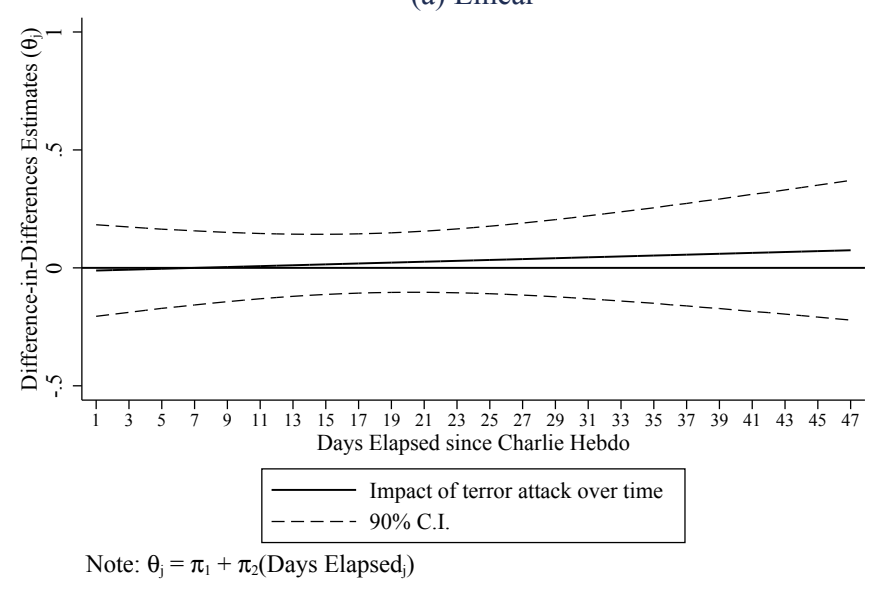

(b) Quadratic

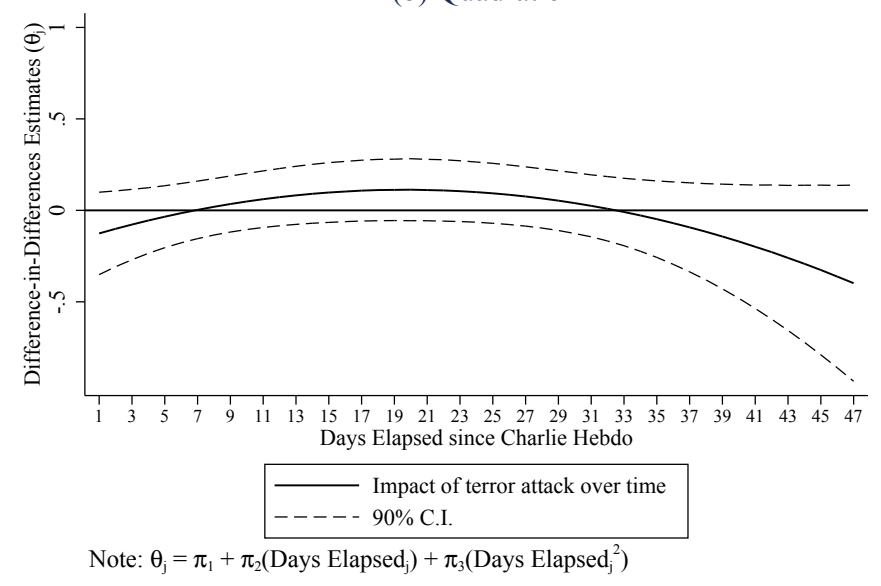

(c) Square Root

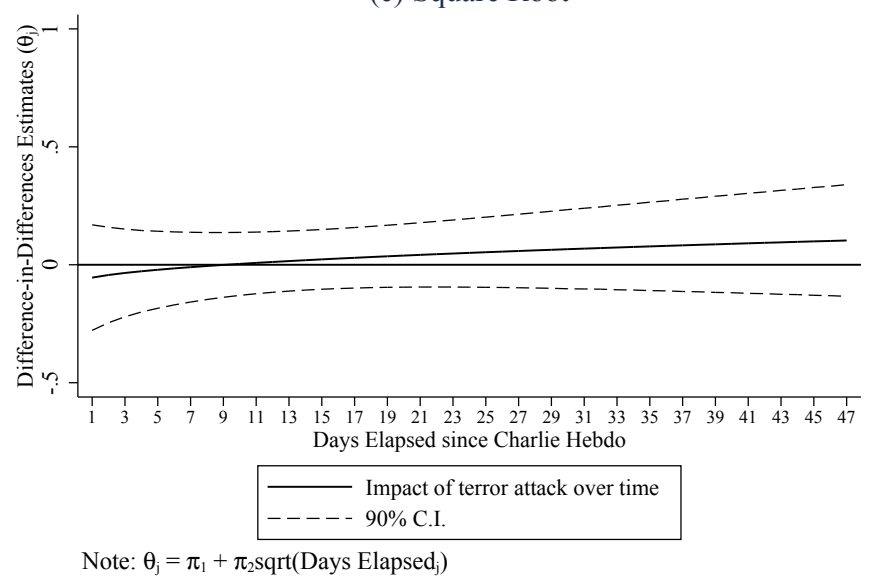


Table A26: Sensitivity to Balancing Countries

\begin{tabular}{|c|c|c|c|c|c|c|}
\hline Dependent Variable: & $\begin{array}{c}\text { Social } \\
\text { Capital } \\
\end{array}$ & $\begin{array}{c}\text { Institutional } \\
\text { Trust } \\
\end{array}$ & $\begin{array}{c}\text { Interpersonal } \\
\text { Trust } \\
\end{array}$ & $\begin{array}{c}\text { Social } \\
\text { Networks } \\
\end{array}$ & Reciprocity & $\begin{array}{c}\text { Ethnic } \\
\text { Tolerance }\end{array}$ \\
\hline (A) [Full Sample] & (1) & $(2)$ & (3) & $(4)$ & $(5)$ & $(6)$ \\
\hline Treat $\mathrm{x}$ Post & $\begin{array}{c}0.262 * * * \\
(0.0730)\end{array}$ & $\begin{array}{r}0.297 * * * \\
(0.0797)\end{array}$ & $\begin{array}{l}0.183^{* *} \\
(0.0736)\end{array}$ & $\begin{array}{c}0.136 \\
(0.0856)\end{array}$ & $\begin{array}{c}0.0540 \\
(0.0816)\end{array}$ & $\begin{array}{c}0.0101 \\
(0.0778)\end{array}$ \\
\hline P-value for test of coefficeint differences & 0.0720 & 0.0126 & 0.907 & 0.741 & 0.327 & 0.421 \\
\hline Observations & 11,012 & 11,012 & 11,012 & 11,012 & 11,012 & 11,012 \\
\hline (B) [-47 days, 47 days $]$ & $(1)$ & $(2)$ & (3) & $(4)$ & $(5)$ & $(6)$ \\
\hline Treat x Post & $\begin{array}{c}0.281 * * * \\
(0.0760)\end{array}$ & $\begin{array}{c}0.327 * * * \\
(0.0817)\end{array}$ & $\begin{array}{c}0.222 * * * \\
(0.0755)\end{array}$ & $\begin{array}{c}0.109 \\
(0.0877)\end{array}$ & $\begin{array}{c}0.0605 \\
(0.0842)\end{array}$ & $\begin{array}{c}0.00703 \\
(0.0804)\end{array}$ \\
\hline P-value for test of coefficeint differences & 0.274 & 0.0741 & 0.994 & 0.982 & 0.598 & 0.691 \\
\hline Observations & 7,985 & 7,985 & 7,985 & 7,985 & 7,985 & 7,985 \\
\hline (C) [-30 days, 30 days] & $(1)$ & $(2)$ & (3) & (4) & $(5)$ & (6) \\
\hline Treat $\mathrm{x}$ Post & $\begin{array}{c}0.269 * * * \\
(0.0978)\end{array}$ & $\begin{array}{c}0.290 * * * \\
(0.102)\end{array}$ & $\begin{array}{l}0.222 * * \\
(0.0955)\end{array}$ & $\begin{array}{c}0.122 \\
(0.105)\end{array}$ & $\begin{array}{l}0.0231 \\
(0.106)\end{array}$ & $\begin{array}{c}0.0471 \\
(0.0957)\end{array}$ \\
\hline P-value for test of coefficeint differences & 0.529 & 0.470 & 0.191 & 0.590 & 0.945 & 0.847 \\
\hline Observations & 5,032 & 5,032 & 5,032 & 5,032 & 5,032 & 5,032 \\
\hline \multicolumn{7}{|l|}{ Baseline covariates and sample definitions } \\
\hline Country FE & $y$ & $y$ & $y$ & $y$ & $y$ & $y$ \\
\hline Demographic controls & $y$ & $y$ & $y$ & $y$ & $y$ & $y$ \\
\hline Week FE & $y$ & $y$ & $y$ & $y$ & $y$ & $y$ \\
\hline Includes bordering countries & $y$ & $y$ & $y$ & $y$ & $y$ & $y$ \\
\hline Includes non-nordering countries & $y$ & $y$ & $y$ & $y$ & $y$ & $y$ \\
\hline \multicolumn{7}{|l|}{ Additional covariates and sample restrictions } \\
\hline Balanced country restriction & $y$ & $y$ & $y$ & $y$ & $y$ & $y$ \\
\hline Marital status & $n$ & $n$ & $n$ & $n$ & $n$ & $n$ \\
\hline Political orientation & $n$ & $n$ & $n$ & $n$ & $n$ & $n$ \\
\hline Citizenship & $n$ & $n$ & $n$ & $n$ & $n$ & $n$ \\
\hline Employment & $n$ & $n$ & $n$ & $n$ & $n$ & $n$ \\
\hline Religiosity & $n$ & $n$ & $n$ & $n$ & $n$ & $n$ \\
\hline Hours spent watching television & $n$ & $n$ & $n$ & $n$ & $n$ & $n$ \\
\hline Country specific linear time trends & $n$ & $n$ & $n$ & $n$ & $n$ & $n$ \\
\hline
\end{tabular}

Notes: $* * * \mathrm{p}<0.01, * * \mathrm{p}<0.05, * \mathrm{p}<0.1$. Robust (Huber-White) standard errors in parentheses. Columns (1) - (6) report coefficient estimates of the treatment group by post Charlie Hebdo interaction terms as specified in estimating equation (1). The social capital index of interest used on the left hand side of estimating equation (1) is reported in the column headings above the column numbers. The set of demographic controls include: Second-order polynomials in age and education (in years); a binary variable indicating if the respondent is female; and a set of categorical variables indicating the decile of the respondent's household's total net income. Balanced country restriction $=\mathrm{y}$ if the estimation sample excludes countries that do not have data on respondents both before and after Charlie Hebdo. Marital status $=\mathrm{y}$ if the model includes a binary variable indicating if the respondent is married. Political orientation $=\mathrm{y}$ if the model includes categorical variables indicating the respondents placement on the left/right scale. Citizenship $=y$ if the model includes a binary variable indicating if the respondent is a citizen. Employment $=y$ if the model includes a binary variable indicating if the respondent is employed. Religiosity $=\mathrm{y}$ if the model includes a binary variable indicating if the respondent is religious. Hours spent watching television $=\mathrm{y}$ if the model includes categorical variables indicating the number of hours of television watched. Lastly, we report the p-value associated with the two-tailed test for differences in the coefficient estimates of Treat $\mathrm{x}$ Post reported above and coefficient estimates of Treat x Post obtained from our most robust baseline specification (e.g. coefficient estimates of Treat $x$ Post obtained from estimating equation (1) using the baseline covariates and sample definitions highlighted above but excluding the additional covariates and sample restrictions highlighted above). 


\section{Table A27: Sensitivity to Additional Controls}

\begin{tabular}{|c|c|c|c|c|c|c|}
\hline Dependent Variable: & $\begin{array}{c}\text { Social } \\
\text { Capital } \\
\end{array}$ & $\begin{array}{c}\text { Institutional } \\
\text { Trust } \\
\end{array}$ & $\begin{array}{c}\text { Interpersonal } \\
\text { Trust } \\
\end{array}$ & $\begin{array}{c}\text { Social } \\
\text { Networks }\end{array}$ & Reciprocity & $\begin{array}{c}\text { Ethnic } \\
\text { Tolerance }\end{array}$ \\
\hline (A) [Full Sample] & $(1)$ & $(2)$ & (3) & (4) & $(5)$ & (6) \\
\hline Treat $\mathrm{x}$ Post & $\begin{array}{c}0.234 * * * \\
(0.0734)\end{array}$ & $\begin{array}{c}0.251 * * * \\
(0.0804)\end{array}$ & $\begin{array}{l}0.166^{* *} \\
(0.0743)\end{array}$ & $\begin{array}{c}0.145 \\
(0.0890)\end{array}$ & $\begin{array}{c}0.0551 \\
(0.0824)\end{array}$ & $\begin{array}{l}-0.0117 \\
(0.0767)\end{array}$ \\
\hline $\mathrm{P}$-value for test of coefficeint differences & 0.129 & 0.0157 & 0.464 & 0.706 & 0.865 & 0.358 \\
\hline Observations & 10,046 & 10,046 & 10,046 & 10,046 & 10,046 & 10,046 \\
\hline (B) [-47 days, 47 days] & $(1)$ & $(2)$ & (3) & $(4)$ & $(5)$ & $(6)$ \\
\hline Treat $x$ Post & $\begin{array}{c}0.262 * * * \\
(0.0761)\end{array}$ & $\begin{array}{c}0.286 * * * \\
(0.0823)\end{array}$ & $\begin{array}{c}0.215 * * * \\
(0.0762)\end{array}$ & $\begin{array}{c}0.118 \\
(0.0910)\end{array}$ & $\begin{array}{c}0.0588 \\
(0.0846)\end{array}$ & $\begin{array}{r}-0.00181 \\
(0.0785)\end{array}$ \\
\hline P-value for test of coefficeint differences & 0.329 & 0.0505 & 0.776 & 0.684 & 0.858 & 0.711 \\
\hline Observations & 7,266 & 7,266 & 7,266 & 7,266 & 7,266 & 7,266 \\
\hline (C) [-30 days, 30 days $]$ & $(1)$ & (2) & (3) & (4) & $(5)$ & $(6)$ \\
\hline Treat $\mathrm{x}$ Post & $\begin{array}{c}0.284 * * * \\
(0.0980)\end{array}$ & $\begin{array}{c}0.323 * * * \\
(0.103)\end{array}$ & $\begin{array}{l}0.244 * * \\
(0.0972)\end{array}$ & $\begin{array}{c}0.134 \\
(0.109)\end{array}$ & $\begin{array}{c}-0.00812 \\
(0.106)\end{array}$ & $\begin{array}{c}0.0498 \\
(0.0958)\end{array}$ \\
\hline $\mathrm{P}$-value for test of coefficeint differences & 0.716 & 0.406 & 0.620 & 0.586 & 0.426 & 0.910 \\
\hline Observations & 4,541 & 4,541 & 4,541 & 4,541 & 4,541 & 4,541 \\
\hline \multicolumn{7}{|l|}{ Baseline covariates and sample definitions } \\
\hline Country FE & $y$ & $y$ & $y$ & $y$ & $y$ & $y$ \\
\hline Demographic controls & $y$ & $y$ & $y$ & $y$ & $y$ & $y$ \\
\hline Week FE & $y$ & $y$ & $y$ & $y$ & $y$ & $y$ \\
\hline Includes bordering countries & $y$ & $y$ & $y$ & $y$ & $y$ & $y$ \\
\hline Includes non-nordering countries & $y$ & $y$ & $y$ & $y$ & $y$ & $y$ \\
\hline \multicolumn{7}{|l|}{ Additional covariates and sample restrictions } \\
\hline Balanced country restriction & $y$ & $y$ & $y$ & $y$ & $y$ & $y$ \\
\hline Marital status & $y$ & $y$ & $y$ & $y$ & $y$ & $y$ \\
\hline Political orientation & $y$ & $y$ & $y$ & $y$ & $y$ & $y$ \\
\hline Citizenship & $y$ & $y$ & $y$ & $y$ & $y$ & $y$ \\
\hline Employment & $y$ & $y$ & $y$ & $y$ & $y$ & $y$ \\
\hline Religiosity & $y$ & $y$ & $y$ & $y$ & $y$ & $y$ \\
\hline Hours spent watching television & $y$ & $y$ & $y$ & $y$ & $y$ & $y$ \\
\hline Country specific linear time trends & $n$ & $n$ & $n$ & $n$ & $n$ & $n$ \\
\hline
\end{tabular}

Notes: $* * * \mathrm{p}<0.01, * * \mathrm{p}<0.05, * \mathrm{p}<0.1$. Robust (Huber-White) standard errors in parentheses. Columns (1) - (6) report coefficient estimates of the treatment group by post Charlie Hebdo interaction terms as specified in estimating equation (1). The social capital index of interest used on the left hand side of estimating equation (1) is reported in the column headings above the column numbers. The set of demographic controls include: Second-order polynomials in age and education (in years); a binary variable indicating if the respondent is female; and a set of categorical variables indicating the decile of the respondent's household's total net income. Balanced country restriction $=\mathrm{y}$ if the estimation sample excludes countries that do not have data on respondents both before and after Charlie Hebdo. Marital status $=\mathrm{y}$ if the model includes a binary variable indicating if the respondent is married. Political orientation $=\mathrm{y}$ if the model includes categorical variables indicating the respondents placement on the left/right scale. Citizenship $=y$ if the model includes a binary variable indicating if the respondent is a citizen. Employment $=\mathrm{y}$ if the model includes a binary variable indicating if the respondent is employed. Religiosity $=\mathrm{y}$ if the model includes a binary variable indicating if the respondent is religious. Hours spent watching television $=\mathrm{y}$ if the model includes categorical variables indicating the number of hours of television watched. Lastly, we report the p-value associated with the two-tailed test for differences in the coefficient estimates of Treat $\mathrm{x}$ Post reported above and coefficient estimates of Treat $\mathrm{x}$ Post obtained from our most robust baseline specification (e.g. coefficient estimates of Treat $\mathrm{x}$ Post obtained from estimating equation (1) using the baseline covariates and sample definitions highlighted above but excluding the additional covariates and sample restrictions highlighted above). 
Table A28: Sensitivity to Linear Time Trends

\begin{tabular}{|c|c|c|c|c|c|c|}
\hline Dependent Variable: & $\begin{array}{c}\text { Social } \\
\text { Capital } \\
\end{array}$ & $\begin{array}{c}\text { Institutional } \\
\text { Trust } \\
\end{array}$ & $\begin{array}{c}\text { Interpersonal } \\
\text { Trust } \\
\end{array}$ & $\begin{array}{c}\text { Social } \\
\text { Networks } \\
\end{array}$ & Reciprocity & $\begin{array}{c}\text { Ethnic } \\
\text { Tolerance } \\
\end{array}$ \\
\hline (A) [Full Sample] & (1) & $(2)$ & (3) & (4) & $(5)$ & (6) \\
\hline Treat $\mathrm{x}$ Post & $\begin{array}{c}0.490 * * * \\
(0.166)\end{array}$ & $\begin{array}{c}0.384 * * \\
(0.167)\end{array}$ & $\begin{array}{c}0.508 * * * \\
(0.166)\end{array}$ & $\begin{array}{c}0.219 \\
(0.170)\end{array}$ & $\begin{array}{l}0.0333 \\
(0.182)\end{array}$ & $\begin{array}{c}0.154 \\
(0.155)\end{array}$ \\
\hline P-value for test of coefficeint differences & 0.132 & 0.620 & 0.0287 & 0.574 & 0.869 & 0.286 \\
\hline Observations & 10,046 & 10,046 & 10,046 & 10,046 & 10,046 & 10,046 \\
\hline (B) [-47 days, 47 days $]$ & $(1)$ & $(2)$ & (3) & $(4)$ & $(5)$ & $(6)$ \\
\hline Treat $\mathrm{x}$ Post & $\begin{array}{c}0.415 * * \\
(0.188)\end{array}$ & $\begin{array}{c}0.256 \\
(0.181)\end{array}$ & $\begin{array}{c}0.456 * * \\
(0.181)\end{array}$ & $\begin{array}{c}0.282 \\
(0.188)\end{array}$ & $\begin{array}{c}-0.00656 \\
(0.200)\end{array}$ & $\begin{array}{c}0.109 \\
(0.164)\end{array}$ \\
\hline P-value for test of coefficeint differences & 0.449 & 0.608 & 0.149 & 0.294 & 0.692 & 0.473 \\
\hline Observations & 7,266 & 7,266 & 7,266 & 7,266 & 7,266 & 7,266 \\
\hline (C) [-30 days, 30 days] & $(1)$ & $(2)$ & (3) & (4) & $(5)$ & (6) \\
\hline Treat $\mathrm{x}$ Post & $\begin{array}{c}0.547 * * \\
(0.248)\end{array}$ & $\begin{array}{c}0.384 \\
(0.242)\end{array}$ & $\begin{array}{l}0.457^{*} \\
(0.241)\end{array}$ & $\begin{array}{l}0.435^{*} \\
(0.253)\end{array}$ & $\begin{array}{c}0.119 \\
(0.259)\end{array}$ & $\begin{array}{l}0.0352 \\
(0.200)\end{array}$ \\
\hline P-value for test of coefficeint differences & 0.219 & 0.689 & 0.303 & 0.178 & 0.672 & 0.950 \\
\hline Observations & 4,541 & 4,541 & 4,541 & 4,541 & 4,541 & 4,541 \\
\hline \multicolumn{7}{|l|}{ Baseline covariates and sample definitions } \\
\hline Country FE & $y$ & $y$ & $y$ & $y$ & $y$ & $y$ \\
\hline Demographic controls & $y$ & $y$ & $y$ & $y$ & $y$ & $y$ \\
\hline Week FE & $y$ & $y$ & $y$ & $y$ & $y$ & $y$ \\
\hline Includes bordering countries & $y$ & $y$ & $y$ & $y$ & $y$ & $y$ \\
\hline Includes non-nordering countries & $y$ & $y$ & $y$ & $y$ & $y$ & $y$ \\
\hline \multicolumn{7}{|l|}{ Additional covariates and sample restrictions } \\
\hline Balanced country restriction & $y$ & $y$ & $y$ & $y$ & $y$ & $y$ \\
\hline Marital status & $y$ & $y$ & $y$ & $y$ & $y$ & $y$ \\
\hline Political orientation & $y$ & $y$ & $y$ & $y$ & $y$ & $y$ \\
\hline Citizenship & $y$ & $y$ & $y$ & $y$ & $y$ & $y$ \\
\hline Employment & $y$ & $y$ & $y$ & $y$ & $y$ & $y$ \\
\hline Religiosity & $y$ & $y$ & $y$ & $y$ & $y$ & $y$ \\
\hline Hours spent watching television & $y$ & $y$ & $y$ & $y$ & $y$ & $y$ \\
\hline Country specific linear time trends & $y$ & $y$ & $y$ & $y$ & $y$ & $y$ \\
\hline \multicolumn{7}{|c|}{$\begin{array}{l}\text { Notes: } * * * \mathrm{p}<0.01, * * \mathrm{p}<0.05, * \mathrm{p}<0.1 \text {. Robust (Huber-White) standard errors in parentheses. Columns (1) - (6) report coefficient } \\
\text { estimates of the treatment group by post Charlie Hebdo interaction terms as specified in estimating equation (1). The social capital } \\
\text { index of interest used on the left hand side of estimating equation (1) is reported in the column headings above the column numbers. } \\
\text { The set of demographic controls include: Second-order polynomials in age and education (in years); a binary variable indicating if the } \\
\text { respondent is female; and a set of categorical variables indicating the decile of the respondent's household's total net income. Balanced } \\
\text { country restriction = y if the estimation sample excludes countries that do not have data on respondents both before and after Charlie } \\
\text { Hebdo. Marital status = y if the model includes a binary variable indicating if the respondent is married. Political orientation = y if the } \\
\text { model includes categorical variables indicating the respondents placement on the left/right scale. Citizenship = y if the model includes a } \\
\text { binary variable indicating if the respondent is a citizen. Employment = y if the model includes a binary variable indicating if the } \\
\text { respondent is employed. Religiosity = y if the model includes a binary variable indicating if the respondent is religious. Hours spent } \\
\text { watching television = y if the model includes categorical variables indicating the number of hours of television watched. Lastly, we } \\
\text { report the p-value associated with the two-tailed test for differences in the coefficient estimates of Treat } x \text { Post reported above and } \\
\text { coefficient estimates of Treat } x \text { Post obtained from our most robust baseline specification (e.g. coefficient estimates of Treat } x \text { Post } \\
\text { obtained from estimating equation (1) using the baseline covariates and sample definitions highlighted above but excluding the additional } \\
\text { covariates and sample restrictions highlighted above). }\end{array}$} \\
\hline
\end{tabular}


Table A29: DID Estimates: Standard Errors Clustered at the Country Level

\begin{tabular}{|c|c|c|c|c|c|c|}
\hline Dependent Variable: & $\begin{array}{c}\text { Social } \\
\text { Capital }\end{array}$ & $\begin{array}{c}\text { Institutional } \\
\text { Trust }\end{array}$ & $\begin{array}{c}\text { Interpersonal } \\
\text { Trust } \\
\end{array}$ & $\begin{array}{c}\text { Social } \\
\text { Networks }\end{array}$ & Reciprocity & $\begin{array}{c}\text { Ethnic } \\
\text { Tolerance }\end{array}$ \\
\hline (A) [Full Sample] & $(1)$ & (2) & (3) & (4) & (5) & $(6)$ \\
\hline Treat $\mathrm{x}$ Post & $\begin{array}{c}0.271 * * * \\
(0.0344)\end{array}$ & $\begin{array}{c}0.311 * * * \\
(0.0433)\end{array}$ & $\begin{array}{c}0.183 * * * \\
(0.0383)\end{array}$ & $\begin{array}{c}0.138 * * * \\
(0.0386)\end{array}$ & $\begin{array}{c}0.0595 \\
(0.0418)\end{array}$ & $\begin{array}{c}0.0145 \\
(0.0162)\end{array}$ \\
\hline Observations & 12,466 & 12,466 & 12,466 & 12,466 & 12,466 & 12,466 \\
\hline (B) [-47 days, 47 days] & $(1)$ & (2) & (3) & (4) & (5) & (6) \\
\hline Treat $x$ Post & $\begin{array}{c}0.288 * * * \\
(0.0365)\end{array}$ & $\begin{array}{c}0.338 * * * \\
(0.0532)\end{array}$ & $\begin{array}{c}0.222 * * * \\
(0.0399)\end{array}$ & $\begin{array}{l}0.109 * * \\
(0.0432)\end{array}$ & $\begin{array}{c}0.0637 \\
(0.0402)\end{array}$ & $\begin{array}{l}0.00953 \\
(0.0167)\end{array}$ \\
\hline Observations & 9,260 & 9,260 & 9,260 & 9,260 & 9,260 & 9,260 \\
\hline (C) [-30 days, 30 days] & (1) & (2) & (3) & (4) & $(5)$ & $(6)$ \\
\hline Treat $\mathrm{x}$ Post & $\begin{array}{c}0.272 * * * \\
(0.0511)\end{array}$ & $\begin{array}{c}0.294 * * * \\
(0.0597)\end{array}$ & $\begin{array}{c}0.229 * * * \\
(0.0669)\end{array}$ & $\begin{array}{c}0.120 * * * \\
(0.0391)\end{array}$ & $\begin{array}{c}0.0227 \\
(0.0391)\end{array}$ & $\begin{array}{l}0.0460 * \\
(0.0229)\end{array}$ \\
\hline Observations & 5,751 & 5,751 & 5,751 & 5,751 & 5,751 & 5,751 \\
\hline Country FE & $y$ & $y$ & $y$ & $y$ & $y$ & $y$ \\
\hline Demographic Controls & $y$ & $y$ & $y$ & $y$ & $y$ & $y$ \\
\hline Week FE & $y$ & $y$ & $y$ & $y$ & $y$ & $y$ \\
\hline Includes Bordering Countries & $y$ & $y$ & $y$ & $y$ & $y$ & $y$ \\
\hline Includes Non-Bordering Countries & $y$ & $y$ & $y$ & $y$ & $y$ & $y$ \\
\hline
\end{tabular}

Notes: *** $\mathrm{p}<0.01, * * \mathrm{p}<0.05,{ }^{*} \mathrm{p}<0.1$. Standard errors shown in parentheses are clustered at the country level. Columns (1) (6) report coefficient estimates of the treatment group by post Charlie Hebdo interaction terms as specified in estimating equation (1). The social capital index of interest used on the left hand side of estimating equation (1) is reported in the column headings above the column numbers. The set of demographic controls include: Second-order polynomials in age and education (in years); a binary variable indicating if the respondent is female; and a set of categorical variables indicating the decile of the respondent's household's total net income. 
Table A30: DID Estimates: Standard Errors Clustered at the Country by Pre/Post Level

\begin{tabular}{|c|c|c|c|c|c|c|}
\hline Dependent Variable: & $\begin{array}{l}\text { Social } \\
\text { Capital }\end{array}$ & $\begin{array}{c}\text { Institutional } \\
\text { Trust } \\
\end{array}$ & $\begin{array}{c}\text { Interpersonal } \\
\text { Trust } \\
\end{array}$ & $\begin{array}{c}\text { Social } \\
\text { Networks }\end{array}$ & Reciprocity & $\begin{array}{c}\text { Ethnic } \\
\text { Tolerance }\end{array}$ \\
\hline (A) [Full Sample] & $(1)$ & $(2)$ & (3) & $(4)$ & $(5)$ & (6) \\
\hline Treat $\mathrm{x}$ Post & $\begin{array}{c}0.271 * * * \\
(0.0299)\end{array}$ & $\begin{array}{r}0.311 * * * \\
(0.0340)\end{array}$ & $\begin{array}{c}0.183 * * * \\
(0.0323)\end{array}$ & $\begin{array}{r}0.138 * * * \\
(0.0318)\end{array}$ & $\begin{array}{c}0.0595 \\
(0.0368)\end{array}$ & $\begin{array}{c}0.0145 \\
(0.0185)\end{array}$ \\
\hline Observations & 12,466 & 12,466 & 12,466 & 12,466 & 12,466 & 12,466 \\
\hline (B) [-47 days, 47 days $]$ & $(1)$ & $(2)$ & (3) & $(4)$ & $(5)$ & $(6)$ \\
\hline Treat $\mathrm{x}$ Post & $\begin{array}{c}0.288^{* * * *} \\
(0.0285)\end{array}$ & $\begin{array}{r}0.338^{* * *} \\
(0.0407)\end{array}$ & $\begin{array}{c}0.222 * * * \\
(0.0325)\end{array}$ & $\begin{array}{r}0.109 * * * \\
(0.0346)\end{array}$ & $\begin{array}{l}0.0637^{*} \\
(0.0343)\end{array}$ & $\begin{array}{l}0.00953 \\
(0.0163)\end{array}$ \\
\hline Observations & 9,260 & 9,260 & 9,260 & 9,260 & 9,260 & 9,260 \\
\hline (C) [-30 days, 30 days $]$ & $(1)$ & $(2)$ & (3) & $(4)$ & $(5)$ & (6) \\
\hline Treat $\mathrm{x}$ Post & $\begin{array}{c}0.272 * * * \\
(0.0376)\end{array}$ & $\begin{array}{c}0.294 * * * \\
(0.0456)\end{array}$ & $\begin{array}{c}0.229 * * * \\
(0.0507)\end{array}$ & $\begin{array}{r}0.120 * * * \\
(0.0345)\end{array}$ & $\begin{array}{c}0.0227 \\
(0.0310)\end{array}$ & $\begin{array}{c}0.0460 \\
(0.0282)\end{array}$ \\
\hline Observations & 5,751 & 5,751 & 5,751 & 5,751 & 5,751 & 5,751 \\
\hline Country FE & $y$ & $y$ & $y$ & $y$ & $y$ & $y$ \\
\hline Demographic Controls & $y$ & $y$ & $y$ & $y$ & $y$ & $y$ \\
\hline Week FE & $y$ & $y$ & $y$ & $y$ & $y$ & $y$ \\
\hline Includes Bordering Countries & $y$ & $y$ & $y$ & $y$ & $y$ & $y$ \\
\hline Includes Non-Bordering Countries & $y$ & $y$ & $y$ & $y$ & $y$ & $y$ \\
\hline
\end{tabular}

Notes: $* * * \mathrm{p}<0.01, * * \mathrm{p}<0.05, * \mathrm{p}<0.1$. Standard errors shown in parentheses are clustered at the country by pre/post level. Columns (1) - (6) report coefficient estimates of the treatment group by post Charlie Hebdo interaction terms as specified in estimating equation (1). The social capital index of interest used on the left hand side of estimating equation (1) is reported in the column headings above the column numbers. The set of demographic controls include: Second-order polynomials in age and education (in years); a binary variable indicating if the respondent is female; and a set of categorical variables indicating the decile of the respondent's household's total net income. 
Table A31: DID Estimates: Standard Errors Clustered at the Country by Week Level

\begin{tabular}{lcccccc}
\hline Dependent Variable: & $\begin{array}{c}\text { Social } \\
\text { Capital }\end{array}$ & $\begin{array}{c}\text { Institutional } \\
\text { Trust }\end{array}$ & $\begin{array}{c}\text { Interpersonal } \\
\text { Trust }\end{array}$ & $\begin{array}{c}\text { Social } \\
\text { Networks }\end{array}$ & Reciprocity & $\begin{array}{c}\text { Ethnic } \\
\text { Tolerance }\end{array}$ \\
\hline (A) [Full Sample] & $(1)$ & $(2)$ & $(3)$ & $(4)$ & $(5)$ & $(6)$ \\
\hline Treat x Post & $0.271^{* * *}$ & $0.311^{* * *}$ & $0.183^{* * *}$ & 0.138 & 0.0595 & 0.0145 \\
& $(0.0756)$ & $(0.0793)$ & $(0.0606)$ & $(0.0918)$ & $(0.0732)$ & $(0.0806)$ \\
Observations & 12,466 & 12,466 & 12,466 & 12,466 & 12,466 & 12,466 \\
\hline (B) [-47 days, 47 days] & $(1)$ & $(2)$ & $(3)$ & $(4)$ & $(5)$ & $(6)$ \\
\hline Treat x Post & $0.288^{* * *}$ & $0.338^{* * *}$ & $0.222^{* * *}$ & 0.109 & 0.0637 & 0.00953 \\
& $(0.0788)$ & $(0.0847)$ & $(0.0617)$ & $(0.0940)$ & $(0.0728)$ & $(0.0818)$ \\
Observations & 9,260 & 9,260 & 9,260 & 9,260 & 9,260 & 9,260 \\
\hline (C) [-30 days, 30 days] & $(1)$ & $(2)$ & $(3)$ & $(4)$ & $(5)$ & $(6)$ \\
\hline Treat x Post & $0.272^{* * *}$ & $0.294^{* * *}$ & $0.229 * * *$ & 0.120 & 0.0227 & 0.0460 \\
& $(0.0904)$ & $(0.105)$ & $(0.0762)$ & $(0.103)$ & $(0.0717)$ & $(0.0914)$ \\
Observations & 5,751 & 5,751 & 5,751 & 5,751 & 5,751 & 5,751 \\
\hline Country FE & $y$ & $y$ & $y$ & $y$ & $y$ & $y$ \\
Demographic Controls & $y$ & $y$ & $y$ & $y$ & $y$ & $y$ \\
Week FE & $y$ & $y$ & $y$ & $y$ & $y$ & $y$ \\
Includes Bordering Countries & $y$ & $y$ & $y$ & $y$ & $y$ & $y$ \\
Includes Non-Bordering Countries & $y$ & $y$ & $y$ & $y$ & $y$ & $y$ \\
\hline N & $y$ & & $y$ & $y$ \\
\hline
\end{tabular}

Notes: $* * * \mathrm{p}<0.01, * * \mathrm{p}<0.05, * \mathrm{p}<0.1$. Standard errors shown in parentheses are clustered at the country by year by week level. Columns (1) - (6) report coefficient estimates of the treatment group by post Charlie Hebdo interaction terms as specified in estimating equation (1). The social capital index of interest used on the left hand side of estimating equation (1) is reported in the column headings above the column numbers. The set of demographic controls include: Second-order polynomials in age and education (in years); a binary variable indicating if the respondent is female; and a set of categorical variables indicating the decile of the respondent's household's total net income. 
Table A32: Scaled Coefficient Estimates of Model Covariates

\begin{tabular}{|c|c|c|c|c|c|c|}
\hline Dependent Variable & $\begin{array}{c}\text { Social } \\
\text { Capital } \\
\end{array}$ & $\begin{array}{c}\text { Institutional } \\
\text { Trust } \\
\end{array}$ & $\begin{array}{c}\text { Interpersonal } \\
\text { Trust } \\
\end{array}$ & $\begin{array}{c}\text { Social } \\
\text { Networks }\end{array}$ & Reciprocity & $\begin{array}{c}\text { Ethnic } \\
\text { Tolerance }\end{array}$ \\
\hline & $(1)$ & $(2)$ & (3) & (4) & $(5)$ & $(6)$ \\
\hline \multicolumn{7}{|l|}{ Covariates } \\
\hline Education $^{\mathrm{a}}$ & $\begin{array}{c}6.264 * * * \\
(1.730)\end{array}$ & $\begin{array}{c}13.34 * * * \\
(3.778)\end{array}$ & $\begin{array}{c}5.471 * * \\
(2.249)\end{array}$ & $\begin{array}{l}4.742 \\
(2.982)\end{array}$ & $\begin{array}{c}2.300 \\
(3.165)\end{array}$ & $\begin{array}{c}6.798 \\
(37.91)\end{array}$ \\
\hline \multicolumn{7}{|l|}{ HH Total Income ${ }^{b}$} \\
\hline $\mathrm{I}\left(2^{\text {nd }}\right.$ decile $)$ & $\begin{array}{c}0.249 \\
(0.180)\end{array}$ & $\begin{array}{l}0.0986 \\
(0.152)\end{array}$ & $\begin{array}{c}0.278 \\
(0.275)\end{array}$ & $\begin{array}{c}1.247 \\
(0.852)\end{array}$ & $\begin{array}{l}-0.724 \\
(1.269)\end{array}$ & $\begin{array}{l}-2.809 \\
(15.43)\end{array}$ \\
\hline $\mathrm{I}\left(3^{\text {rd }}\right.$ decile $)$ & $\begin{array}{c}0.284 \\
(0.181)\end{array}$ & $\begin{array}{c}0.217 \\
(0.157)\end{array}$ & $\begin{array}{c}0.851 * * \\
(0.421)\end{array}$ & $\begin{array}{c}1.013 \\
(0.713)\end{array}$ & $\begin{array}{l}-0.857 \\
(1.409)\end{array}$ & $\begin{array}{l}-10.71 \\
(57.33)\end{array}$ \\
\hline $\mathrm{I}\left(4^{\text {th }}\right.$ decile $)$ & $\begin{array}{c}0.556 * * \\
(0.221)\end{array}$ & $\begin{array}{c}0.465^{* * *} \\
(0.190)\end{array}$ & $\begin{array}{c}0.988 * * \\
(0.469)\end{array}$ & $\begin{array}{c}1.389 \\
(0.919)\end{array}$ & $\begin{array}{l}-0.428 \\
(0.958)\end{array}$ & $\begin{array}{l}-9.448 \\
(50.66)\end{array}$ \\
\hline $\mathrm{I}\left(5^{\text {th }}\right.$ decile $)$ & $\begin{array}{c}0.882 * * * \\
(0.288)\end{array}$ & $\begin{array}{c}0.521^{* * * *} \\
(0.196)\end{array}$ & $\begin{array}{l}1.620 * * \\
(0.694)\end{array}$ & $\begin{array}{c}1.799 \\
(1.168)\end{array}$ & $\begin{array}{l}-0.263 \\
(0.825)\end{array}$ & $\begin{array}{l}-6.765 \\
(36.25)\end{array}$ \\
\hline $\mathrm{I}\left(6^{\text {th }}\right.$ decile $)$ & $\begin{array}{c}0.948 * * * \\
(0.303)\end{array}$ & $\begin{array}{c}0.774 * * * \\
(0.245)\end{array}$ & $\begin{array}{c}2.162 * * \\
(0.901)\end{array}$ & $\begin{array}{c}1.696 \\
(1.106)\end{array}$ & $\begin{array}{l}-1.179 \\
(1.787)\end{array}$ & $\begin{array}{l}-13.52 \\
(72.43)\end{array}$ \\
\hline $\mathrm{I}\left(7^{\text {th }}\right.$ decile $)$ & $\begin{array}{c}0.988 * * * \\
(0.317)\end{array}$ & $\begin{array}{c}0.756 * * * \\
(0.243)\end{array}$ & $\begin{array}{c}2.267 * * \\
(0.943)\end{array}$ & $\begin{array}{c}2.115 \\
(1.353)\end{array}$ & $\begin{array}{l}-1.695 \\
(2.438)\end{array}$ & $\begin{array}{l}-14.52 \\
(77.82)\end{array}$ \\
\hline $\mathrm{I}\left(8^{\text {th }}\right.$ decile $)$ & $\begin{array}{c}1.243 * * * \\
(0.374)\end{array}$ & $\begin{array}{c}0.936 * * * \\
(0.283)\end{array}$ & $\begin{array}{c}2.238 * * \\
(0.929)\end{array}$ & $\begin{array}{c}2.717 \\
(1.729)\end{array}$ & $\begin{array}{l}-0.998 \\
(1.582)\end{array}$ & $\begin{array}{l}-13.57 \\
(72.40)\end{array}$ \\
\hline $\mathrm{I}\left(9^{\text {th }}\right.$ decile $)$ & $\begin{array}{c}1.560 * * * \\
(0.455)\end{array}$ & $\begin{array}{c}1.444 * * * \\
(0.402)\end{array}$ & $\begin{array}{c}2.649 * * \\
(1.091)\end{array}$ & $\begin{array}{c}2.775 \\
(1.760)\end{array}$ & $\begin{array}{l}-1.301 \\
(1.948)\end{array}$ & $\begin{array}{l}-14.12 \\
(75.60)\end{array}$ \\
\hline $\mathrm{I}\left(10^{\text {th }}\right.$ decile $)$ & $\begin{array}{c}1.778 * * * \\
(0.515)\end{array}$ & $\begin{array}{c}1.382 * * * \\
(0.385)\end{array}$ & $\begin{array}{c}3.072 * * \\
(1.265)\end{array}$ & $\begin{array}{c}3.520 \\
(2.224)\end{array}$ & $\begin{array}{l}-1.116 \\
(1.713)\end{array}$ & $\begin{array}{l}-15.56 \\
(83.22)\end{array}$ \\
\hline Observations & 12,466 & 12,466 & 12,466 & 12,466 & 12,466 & 12,466 \\
\hline
\end{tabular}

Notes: *** $\mathrm{p}<0.01, * * \mathrm{p}<0.05,{ }^{*} \mathrm{p}<0.1$. Robust (Huber-White) standard errors in parentheses. Columns (1) - (6) report scaled coefficient estimates from estimating equation (1) which includes country FE, week FE and the set of demographic controls. The social capital index of interest used on the left hand side of estimating equation (1) is reported in the column headings above the column numbers. The set of demographic controls included in each model estimate are: Second-order polynomials in age and education (in years); a binary variable indicating if the respondent is female; and a set of categorical variables indicating the decile of the respondent's household's total net income. Model estimates are based on the full sample of countries using the broadest time window available of [-68 days, 47 days]. ${ }^{a}$ As indicated in Appendix A.2.4 we re-scale coefficients to represent how much each covariate would need to change in order to mimic the effects of the attack. For education, we report the effect of the attack on social capital divided by the marginal effect associated with increasing education by one year on social capital. ${ }^{\mathrm{b}}$ For binary regressors, we re-scale coefficients to express what proportion of the Charlie Hebdo effect can be captured by turning particular regressors on and off. For the complete set of binary indicators capturing the income distribution, we divide coefficient estimates of each covariate by the estimated effect of Charlie Hebdo. 
Table A33: Placebo Test - Timing of Event

\begin{tabular}{|c|c|c|c|c|c|c|}
\hline Dependent Variable: & $\begin{array}{l}\text { Social } \\
\text { Capital }\end{array}$ & $\begin{array}{c}\text { Institutional } \\
\text { Trust }\end{array}$ & $\begin{array}{c}\text { Interpersonal } \\
\text { Trust }\end{array}$ & $\begin{array}{c}\text { Social } \\
\text { Networks }\end{array}$ & Reciprocity & $\begin{array}{c}\text { Ethnic } \\
\text { Tolerance }\end{array}$ \\
\hline (A) [-68 Days, -1 Day] & (1) & (2) & (3) & (4) & (5) & (6) \\
\hline Treat x I(-35 Days, -1 Day) & $\begin{array}{c}0.0722 \\
(0.0711)\end{array}$ & $\begin{array}{c}0.127 * \\
(0.0685)\end{array}$ & $\begin{array}{l}0.00402 \\
(0.0673)\end{array}$ & $\begin{array}{c}0.0644 \\
(0.0663)\end{array}$ & $\begin{array}{l}0.00923 \\
(0.0734)\end{array}$ & $\begin{array}{l}-0.0211 \\
(0.0701)\end{array}$ \\
\hline Observations & 8,322 & 8,322 & 8,322 & 8,322 & 8,322 & 8,322 \\
\hline (B) [-47 Days, -1 Day] & $(1)$ & (2) & (3) & $(4)$ & $(5)$ & (6) \\
\hline Treat x I(-24 Days, -1 Day) & $\begin{array}{l}-0.0801 \\
(0.109)\end{array}$ & $\begin{array}{c}0.120 \\
(0.101)\end{array}$ & $\begin{array}{l}-0.101 \\
(0.102)\end{array}$ & $\begin{array}{l}-0.0648 \\
(0.0986)\end{array}$ & $\begin{array}{l}-0.108 \\
(0.116)\end{array}$ & $\begin{array}{l}-0.0796 \\
(0.0932)\end{array}$ \\
\hline Observations & 5,116 & 5,116 & 5,116 & 5,116 & 5,116 & 5,116 \\
\hline (C) [-30 Days, -1 Day] & $(1)$ & $(2)$ & (3) & $(4)$ & $(5)$ & $(6)$ \\
\hline Treat x I(-15 Days, -1 Day) & $\begin{array}{c}-0.0276 \\
(0.224)\end{array}$ & $\begin{array}{l}0.0926 \\
(0.218)\end{array}$ & $\begin{array}{c}-0.0454 \\
(0.231)\end{array}$ & $\begin{array}{l}-0.217 \\
(0.189)\end{array}$ & $\begin{array}{c}0.128 \\
(0.228)\end{array}$ & $\begin{array}{r}-0.0486 \\
(0.161)\end{array}$ \\
\hline Observations & 2,355 & 2,355 & 2,355 & 2,355 & 2,355 & 2,355 \\
\hline Country FE & $y$ & $y$ & $y$ & $y$ & $y$ & $y$ \\
\hline Demographic Controls & $y$ & $y$ & $y$ & $y$ & $y$ & $y$ \\
\hline Week FE & $y$ & $y$ & $y$ & $y$ & $y$ & $y$ \\
\hline Includes Bordering Countries & $y$ & $y$ & $y$ & $y$ & $y$ & $y$ \\
\hline Includes Non-Bordering Countries & $y$ & $y$ & $y$ & $y$ & $y$ & $y$ \\
\hline \multicolumn{7}{|c|}{$\begin{array}{l}\text { Notes: } * * * \mathrm{p}<0.01, * * \mathrm{p}<0.05, * \mathrm{p}<0.1 \text {. Robust (Huber-White) standard errors in parentheses. Columns (1) - (6) report } \\
\text { coefficient estimates of estimating equation (1) restricting attention to observations before the onset of Charlie Hebdo (e.g. the } \\
\text { number of days elapsed since Charlie Hebdo is between }-68 \text { and }-1 \text { ). The indicator variable Treat equals one for France and } \\
\text { zero otherwise. In panel (A), the indicator variable I(-35 Days, }-1 \text { Day) is set equal to one for any period of time such that the } \\
\text { number of days elapsed since Charlie Hebdo is between }-35 \text { and }-1 \text {; models restrict attention to }-68 \text { days to - } 1 \text { day. In panel } \\
\text { (B), the indicator variable I(-24 Days, }-1 \text { Day) is set equal to one for any period of time such that the number of days elapsed } \\
\text { since Charlie Hebdo is between }-24 \text { and }-1 \text {; models restrict attention to }-47 \text { days to - } 1 \text { day. In panel (C), the indicator variable } \\
\text { I(-15 Days, }-1 \text { Day) is set equal to one for any period of time such that the number of days elapsed since Charlie Hebdo is } \\
\text { between }-15 \text { and -1; models restrict attention to -30 days to - } 1 \text { day. Finally, the social capital index of interest used on the left } \\
\text { hand side of estimating equation (1) is reported in the column headings above the column numbers. The set of demographic } \\
\text { controls include: Second-order polynomials in age and education (in years); a binary variable indicating if the respondent is } \\
\text { female; and a set of categorical variables indicating the decile of the respondent's household's total net income. }\end{array}$} \\
\hline
\end{tabular}


Table A34: Regression Discontinuity Estimates - France (Attitudes Towards Immigration Index)

\begin{tabular}{lc}
\hline Dependent Variable: & $\begin{array}{c}\text { Attitudes Towards } \\
\text { Immigrants }\end{array}$ \\
\hline (A) [Full Sample] & $(1)$ \\
\hline Post & 0.165 \\
& $(0.163)$ \\
Days Since & -0.00157 \\
& $(0.00289)$ \\
Days Since x Post & -0.000665 \\
Observations & $(0.00620)$ \\
\hline (B) [-47 days, 47 days] & 1,765 \\
\hline Post & $(1)$ \\
Days Since & 0.116 \\
Days Since x Post & $(0.178)$ \\
Observations & 0.000122 \\
\hline (C) [-30 days, 30 days] & $(0.00372)$ \\
\hline Post & -0.00242 \\
& $(0.00661)$ \\
Days Since & 1,504 \\
Days Since x Post & $(1)$ \\
Observations & 0.282 \\
\hline
\end{tabular}

Notes: $* * * \mathrm{p}<0.01, * * \mathrm{p}<0.05, * \mathrm{p}<0.1$. Robust (Huber-White) standard errors in parentheses. Columns (1) reports coefficient estimates of estimating equation (6). The set of demographic controls include: Second-order polynomials in age and education (in years); a binary variable indicating if the respondent is female; and a set of categorical variables indicating the decile of the respondent's household's total net income. 